\section{Pacific Northwest} National Laboratory

Operated by Battelle for the U.S. Department of Energy

\title{
Groundwater Quality Assessment Plan for Single-Shell Tank Waste Management Area U
}

\author{
R. M. Smith \\ F. N. Hodges \\ B. A. Williams
}

August 2001

Prepared for the U.S. Department of Energy under Contract DE-AC06-76RL01830 


\title{
DISCLAIMER
}

This report was prepared as an account of work sponsored by an agency of the United States Government. Reference herein to any specific commercial product, process, or service by trade name, trademark, manufacturer, or otherwise does not necessarily constitute or imply its endorsement, recommendation, or favoring by the United States Government or any agency thereof, or Battelle Memorial Institute.

\author{
PACIFIC NORTHWEST NATIONAL LABORATORY \\ operated by \\ BATTELLE \\ for the \\ UNITED STATES DEPARTMENT OF ENERGY \\ under Contract DE-AC06-76RL01830
}

Printed in the United States of America

$\Delta$ This document was printed on recycled paper. 


\title{
Groundwater Quality Assessment Plan for Single-Shell Tank Waste Management Area U
}

\author{
R. M. Smith \\ F. N. Hodges \\ B. A. Williams
}

August 2001

Prepared for

the U.S. Department of Energy

under Contract DE-AC06-76RL01830

Pacific Northwest National Laboratory

Richland, Washington 99352 


\section{Summary}

Single-shell tank Waste Management Area U (WMA U) is in the 200 West Area on the Hanford Site. The area includes the $\mathrm{U}$ tank farm that contains 16 underground, single-shell tanks and their ancillary equipment and waste systems. WMA $\mathrm{U}$ is regulated under the Resource Conservation and Recovery Act of 1976 (RCRA) as codified in 40 CFR Part 265, Subpart F and Washington's Hazardous Waste Management Act (HWMA, RCW 70.105) and its implementing requirements in the Washington State dangerous waste regulations (WAC 173-303-400).

Releases of hazardous wastes from WMA U have contaminated groundwater beneath the area. Therefore, WMA $U$ is being assessed to determine the rate of movement and extent of the contamination released and to determine the concentrations in groundwater. The original finding of groundwater impact was determined from elevated specific conductance in downgradient well 299-W19-41. The elevated specific conductance was attributed to the nonhazardous constituents calcium, magnesium, sulfate, and chloride. Tank waste constituents nitrate and technetium-99 are also present as co-contaminants and have increased over the past several years; however, at concentrations well below the respective drinking water standards. Chromium concentrations in downgradient wells have generally exceeded background levels, but similar levels were also observed in upgradient well 299-W18-25 in early 2000 before it went dry.

The objective of this report is to present the current conceptual model for how and where contaminant releases have reached the water table and how that contamination has dispersed in the groundwater system. These efforts will achieve the requirements of a groundwater quality assessment under RCRA [40 CFR 265.93 (d)(4)]. On that basis, a monitoring schedule with appropriate analytes and proposals for new wells and tests are presented in this document. 


\section{Contents}

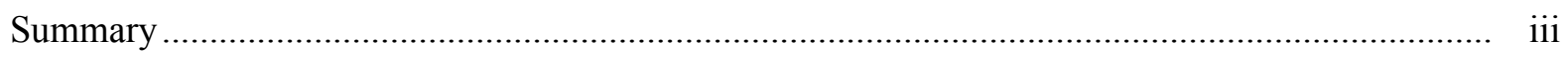

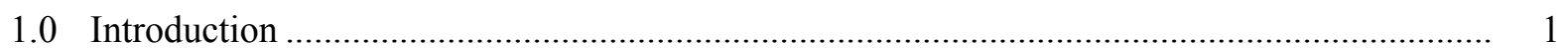

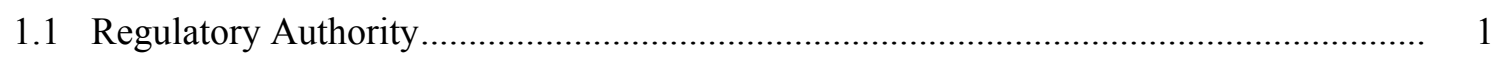

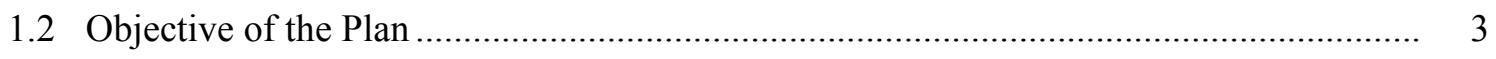

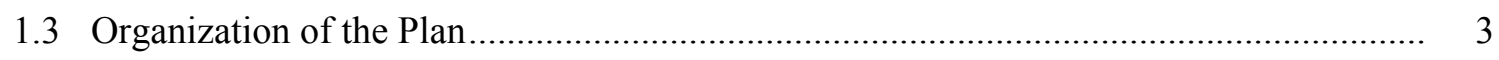

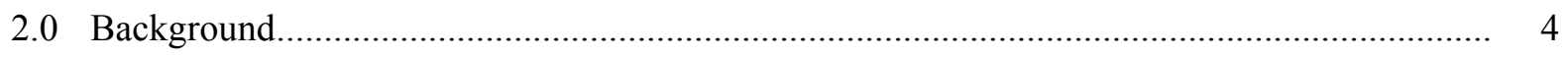

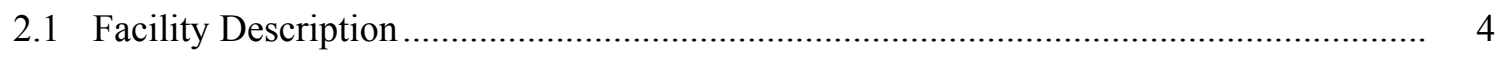

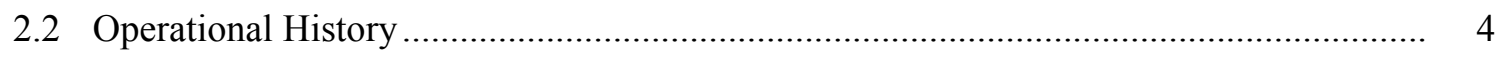

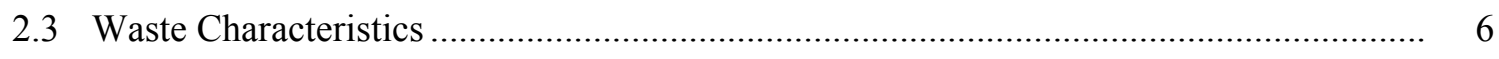

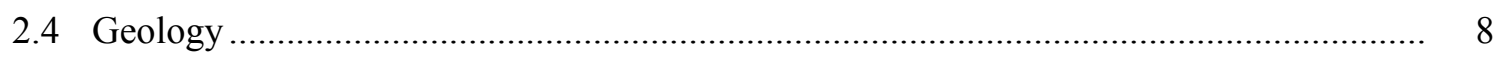

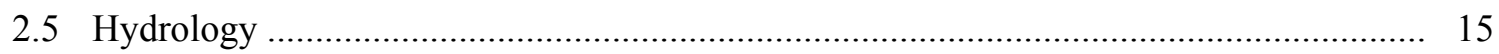

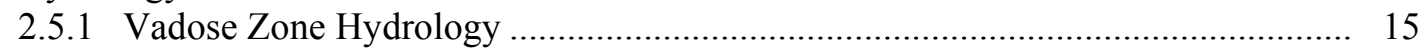

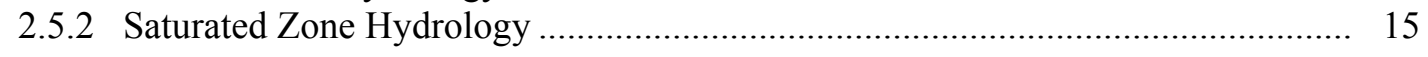

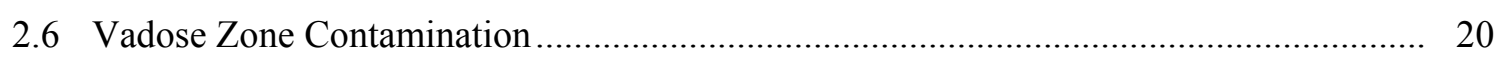

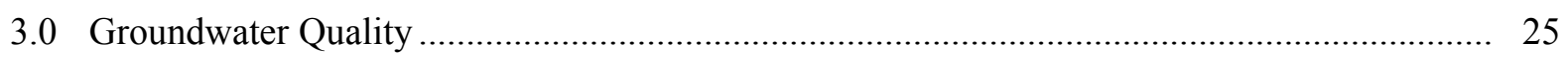

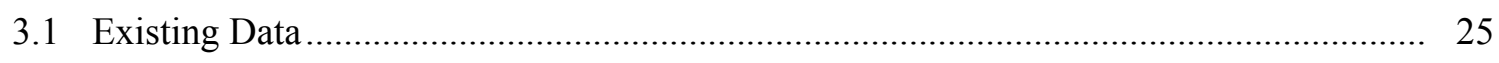

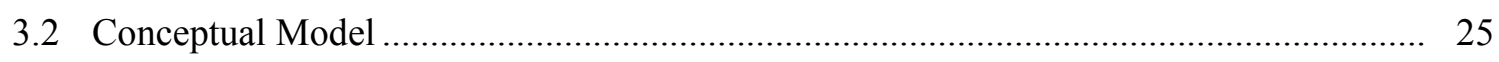

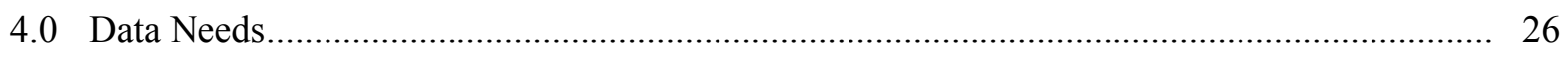

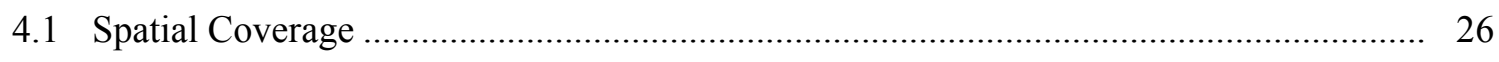

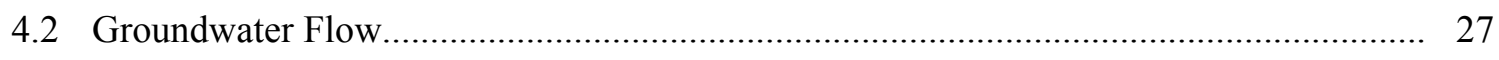

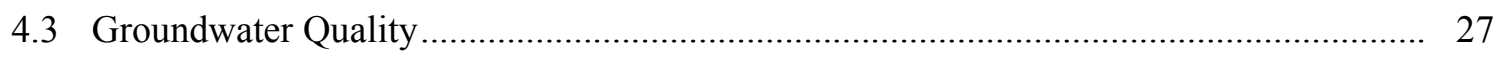

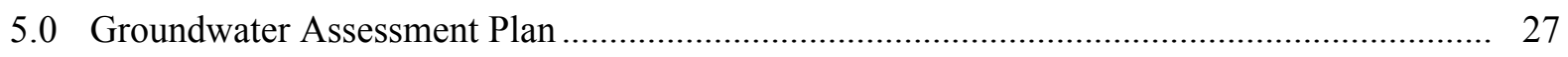

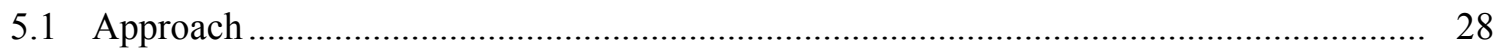

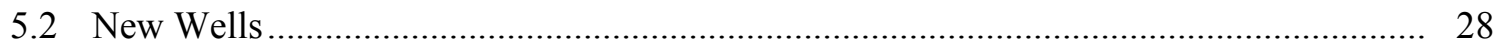




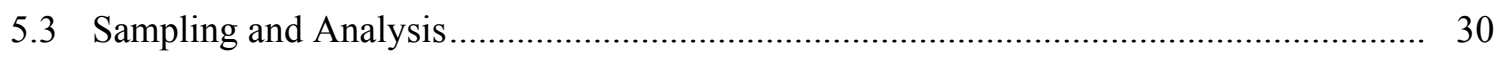

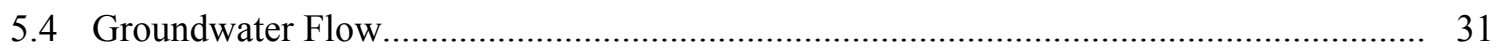

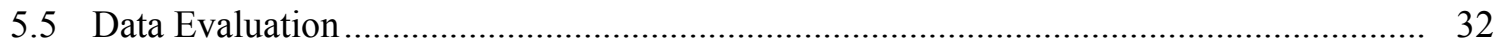

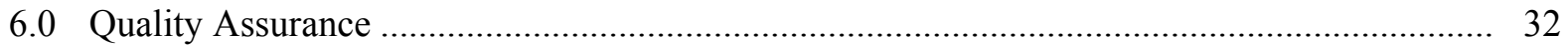

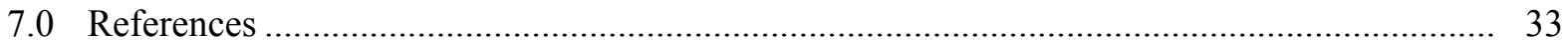

Appendix A - Preliminary Assessment of the Hydrologic Impact of the Shutdown of ZP-1 Extraction Well 299-W15-37 within the Waste Management Area U...................... A.1

Appendix B - Well Construction and Completion Summaries ................................................... B.1 


\section{Figures}

1.1 Location of Waste Management Area U in the 200 West Area of the Hanford Site................ 2

2.1 Waste Management Area U and Regulated Structures.................................................... 5

2.2 North-South Geologic Cross-Section ........................................................................ 9

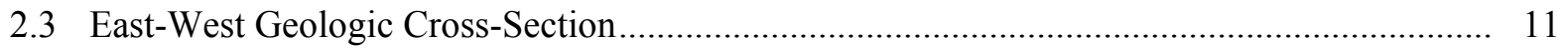

2.4 Water Table in the Vicinity of Waste Management Area U, March 2000 ........................... 13

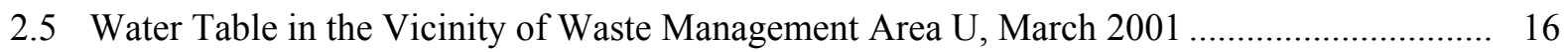

2.6 Hydrographs for Groundwater Monitoring Wells at Waste Management Area U.................. 18

2.7 Screened Interval Relative to Current and Future Water Levels ........................................ 19

2.8 Distribution of Gamma Emitting Radionuclides at Various Depths in Waste

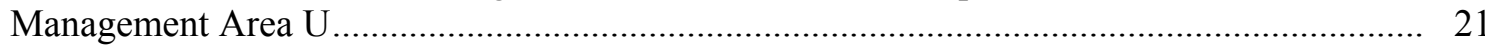

2.9 Three-Dimensional Distribution of Gamma Radionuclides Beneath Waste

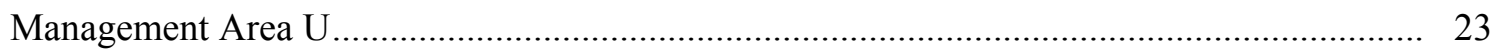

5.1 Proposed New Wells for Waste Management Area U .................................................... 29

\section{Tables}

2.1 Summary of Tank Leaks at Waste Management Area U ................................................. 6

2.2 Selected Waste Constituents in Tanks at Waste Management Area U.................................. 7

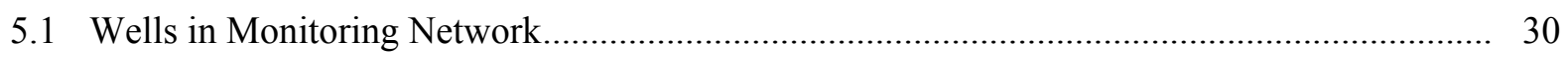

5.2 Sampling Frequency and Constituent List................................................................. 31 


\subsection{Introduction}

Single-shell tank Waste Management Area U (WMA U) consists of 16 single-shell underground tanks, 8 diversion boxes, and associated pipelines and valve boxes. In the normal operation of these structures, leaks and spills released hazardous and radioactive constituents into the surrounding soils. In 2000, the WMA U was determined to have affected groundwater quality (Hodges and Chou 2000); therefore, a plan must be prepared to determine the rate of contaminant migration and the extent of that impact. Specifically, the plan must describe the steps to delineate the concentrations of groundwater contamination and the rate and extent of contaminant migration. The ultimate goal of this work is to provide information necessary for decisions regarding control and remediation of WMA U impacts.

\subsection{Regulatory Authority}

WMA U, located on the Hanford Site (Figure 1.1), was used to store high-level radioactive liquid and entrained solid wastes. The Hanford Federal Facility Agreement and Consent Order (commonly known as the Tri-Party Agreement; Washington State Department of Ecology et al. 1989 as amended) placed WMA U under the authority of the Resource Conservation and Recovery Act of 1976 (RCRA) interim status regulation. The Tri-Party Agreement also placed the interim status sites under the supervision of the Washington State Department of Ecology. In accordance with these decisions, WMA U is now regulated under RCRA interim status regulations as codified in 40 CFR Part 265, Subpart F and Washington State dangerous waste regulations (WAC 173-303-400).

The U.S. Department of Energy (DOE) submitted a RCRA Part A (interim status) permit application and closure/work plan in 1989 to include all RCRA facilities at Hanford. Since that time, some RCRA sites have been included in the RCRA Part B (final status) permit. As prescribed under Tri-Party Agreement Major Milestone M-45-00, single-shell tank farm WMAs will be closed in accordance with WAC 173-303-610, but the tanks will remain and be closed under interim status regulations. The time and method of closure are uncertain, but the current version of the milestone requires closure of all singleshell tank farms by the end of FY 2024. In the meantime, groundwater beneath the WMA U must continue to be monitored.

Starting in 1991, groundwater beneath WMA U was monitored by an interim status indicator evaluation system that compared concentrations of contamination indicator parameters in downgradient wells to background concentrations of the same constituents established from upgradient wells. Groundwater flow directions changed approximately $180^{\circ}$ twice since 1991 and background concentrations were reestablished to accommodate those changes. The most recent recalculation was done in August 1999.

At that time, one of the indicator parameters, specific conductance, exceeded its background value in one downgradient well, 299-W19-41, triggering a change from detection monitoring to a groundwater quality assessment (Hodges and Chou 2000). 


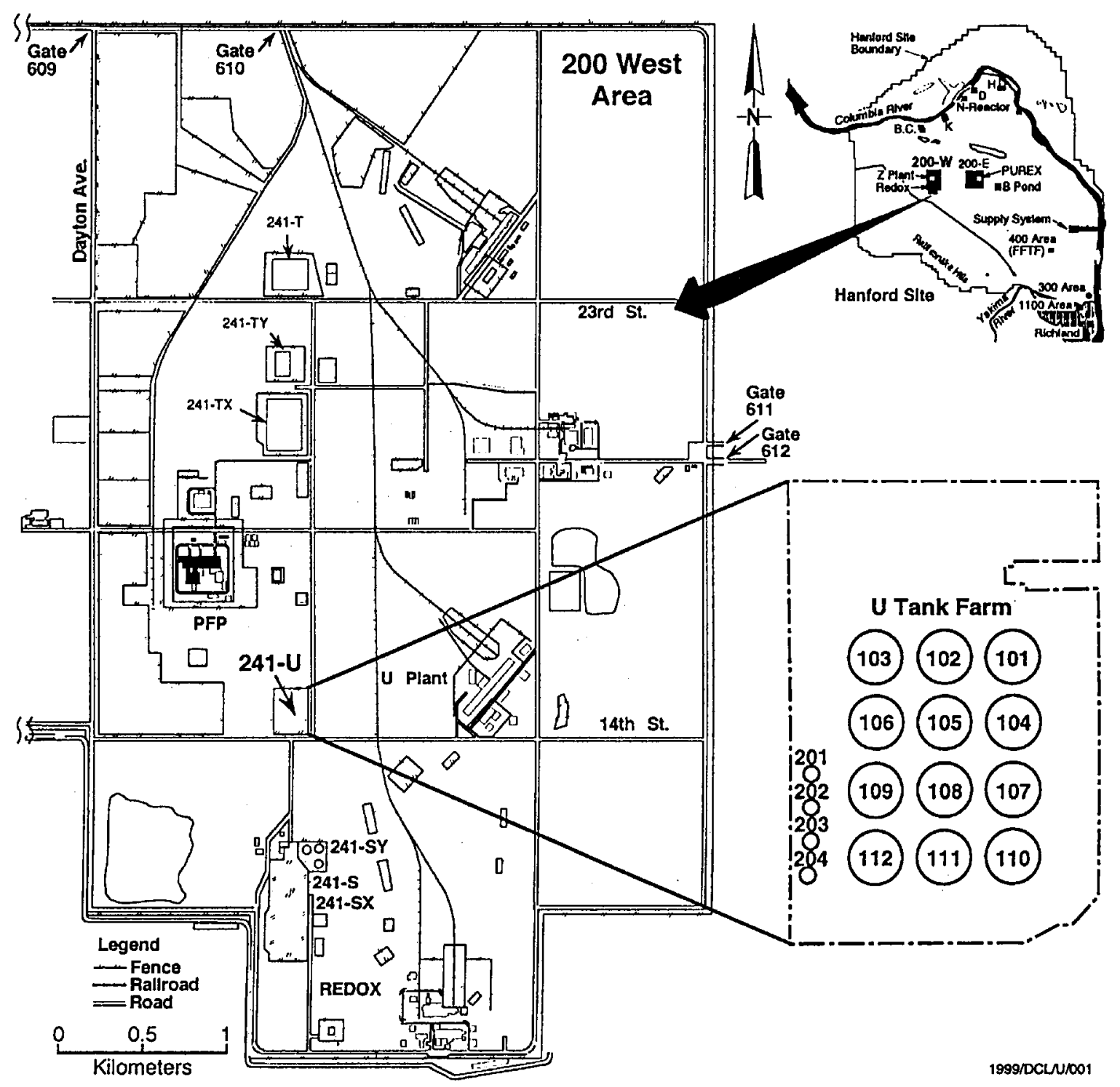

Figure 1.1. Location of Waste Management Area U in the 200 West Area of the Hanford Site

Major contributors to the higher downgradient-specific conductance are nonhazardous constituents, including calcium, magnesium, sulfate, and chloride. Nitrate and technetium-99 are also present as co-contaminants and have increased over the past several years, however, at concentrations well below their respective drinking water standards. Chromium and nitrate concentrations in downgradient wells have generally exceeded background levels, but similar levels were also observed in upgradient well 299-W18-25 in early 2000 before it went dry. The higher upgradient chromium concentrations were accompanied by elevated nickel, iron, manganese, chloride, and turbidity, of which only chloride was elevated in downgradient wells. 


\subsection{Objective of the Plan}

The objective of this plan is to delineate specific actions necessary to determine the rate and extent of migration of hazardous wastes constituents and the concentrations of those constituents in the groundwater. Specific actions include well drilling, hydrologic characterization to determine groundwater flow direction and velocity, and groundwater quality characterization to delineate the extent and concentrations of specific hazardous and radioactive contaminants.

\subsection{Organization of the Plan}

The plan is organized as follows:

- Chapter 1.0 - Introduction

- Chapter 2.0 - Background including a brief description of facilities in the WMA U, associated operations, waste characteristics, site geology, and hydrology as they impact contaminant migration, and a summary of known vadose zone contamination from spectral gamma logging

- Chapter 3.0 - Groundwater Quality including our current understanding of groundwater quality beneath the WMA and a description of conceptual models by which contaminants from the WMA have and may in the future impact groundwater quality

- Chapter 4.0 - Data Needs required to characterize the rate of movement and extent of contamination and contaminant concentrations

- Chapter 5.0 - Groundwater Assessment Plan presenting specific actions to collect those data identified in Chapter 4.0

- Chapter 6.0 - Quality Assurance

- $\quad$ Chapter 7.0 - References

- Appendix A contains a supporting hydrology letter report

- Appendix B provides as-built drawings for the existing monitoring wells. 


\subsection{Background}

\subsection{Facility Description}

WMA U occupies an area of $\sim 30,000 \mathrm{~m}^{2}$ and contains 16 underground single-shell tanks constructed between 1943 and 1944 (Figure 2.1). Twelve tanks (U-101 through U-112) have capacities of 2,017,000 L and four tanks (U-201 through U-204) have capacities of 208,000 L. In addition to the tanks, eight diversion boxes, four valve boxes, and associated underground piping are included in the WMA.

The tanks consist of a reinforced concrete tank with a carbon steel liner that extends across the bottom of the tanks and approximately $6 \mathrm{~m}$ up the walls of the tanks. The concrete dome top is unlined. The larger tanks are $22.9 \mathrm{~m}$ in diameter and are $\sim 9 \mathrm{~m}$ in height. The bottom of the tanks are $\sim 11 \mathrm{~m}$ below grade with $\sim 2 \mathrm{~m}$ of fill over the top. Various ports in the tank tops are available for waste transfer and monitoring. In addition, vadose zone monitoring wells (dry wells) are located in the fill material around the tanks to allow monitoring of radionuclide migration around the tanks using geophysical (gamma logging) methods. The smaller tanks are $6.1 \mathrm{~m}$ in diameter and $7.8 \mathrm{~m}$ in height. The bottom of the smaller tanks are at $\sim 11.3 \mathrm{~m}$ below grade with $\sim 3.6 \mathrm{~m}$ of fill over the top. Buried waste transfer lines run into the farm to diversion boxes where wastes were routed to various tanks through valve boxes.

\subsection{Operational History}

The tanks began receiving waste in 1946 (Anderson 1990) and were in more-or-less continual use from that time until 1980. A more detailed history of operations is presented in Hodges and Chou (2000).

Four of the tanks in the WMA have been declared leakers based on liquid losses and, in the case of tank U-104, a known tank rupture (Anderson 1990; DOE 1992; Hanlon 1996). Information about these leaks is presented in Table 2.1. There is considerable uncertainty in the reported leak volumes, but it is believed that this waste liquid constitutes part of the source of contaminants that have affected groundwater quality. All four tanks have been stabilized and contain little or no pumpable liquid.

In addition to the leaks, three unplanned releases have been documented (DOE 1992). The releases were at ground surface or near surface and waste volumes associated with these unplanned releases are unknown. The releases may have resulted in significant spread of contamination. One release consisted of beta contamination of up to $20 \mathrm{mR} / \mathrm{hr}$ at the surface in the vicinity of the 241-U-151 and 241-U-152 diversion boxes east of the south end of the WMA (UN-200-W-6) in 1950. The second release consisted of a "violent chemical reaction" in a blending tank in the 244-UR vault located on the north end of the WMA that spread first-cycle metal waste contamination over an unspecified area (UPR-200-W-24) in 1953. This release continued to spread to the north beyond the fence where it is roped off and identified as a radiation area. The third release involved a ruptured buried waste line at tank U-103 (UPR-200W-128) in 1971. DOE (1997) reported significant surface contamination within the tank farm and evidence for several additional unreported releases. 


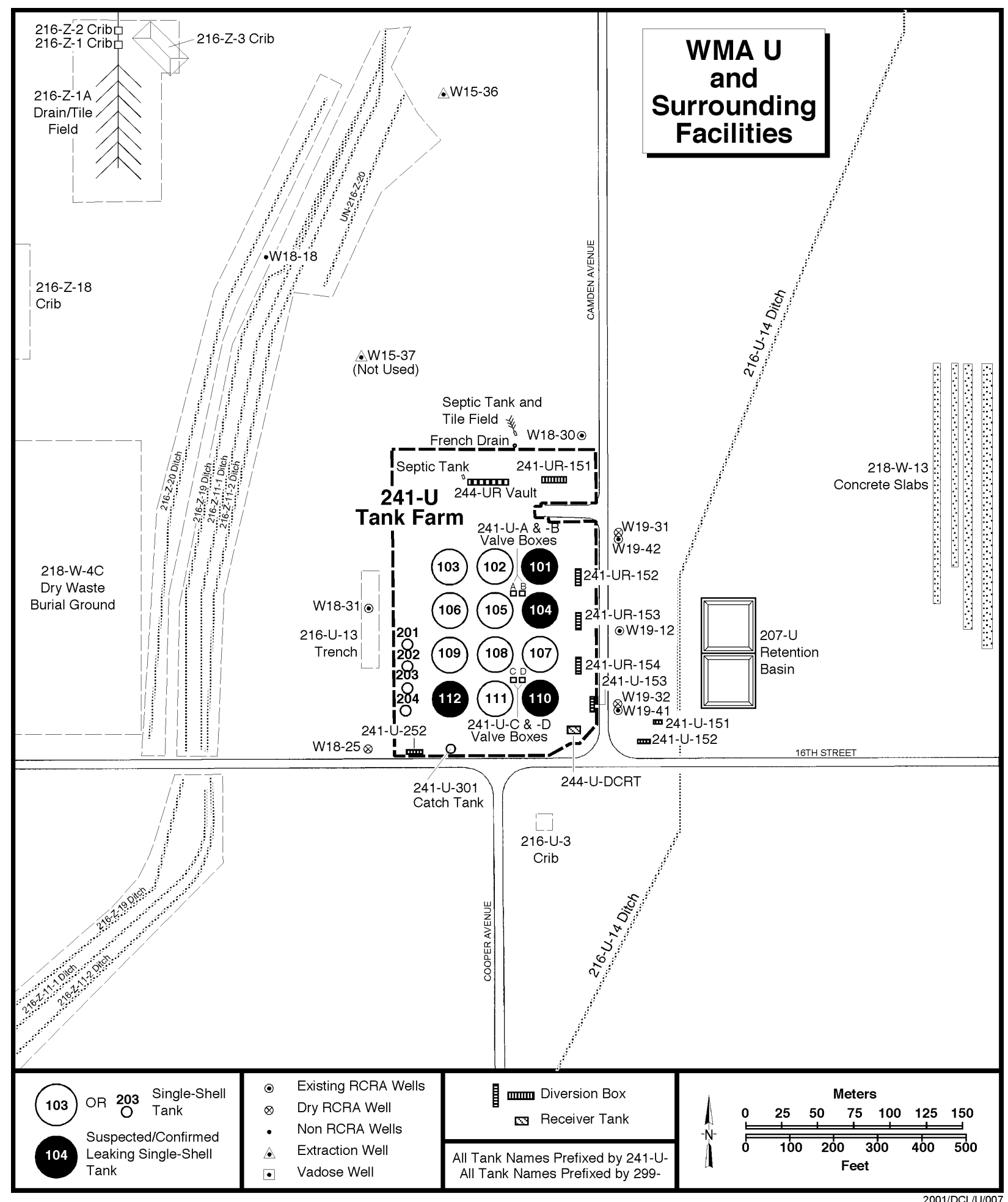

Figure 2.1. Waste Management Area U and Regulated Structures 
Table 2.1. Summary of Tank Leaks at Waste Management Area U

\begin{tabular}{||c|c|c|c||}
\hline Tank & Location in WMA & Date Leak Declared & $\begin{array}{c}\text { Estimated Leak } \\
\text { Volume (L) }\end{array}$ \\
\hline \hline U-101 & NE Corner & 1959 & 114,000 \\
\hline U-104 & E Central & 1954 & 208,000 \\
\hline U-110 & SE Corner & 1975 & 31,000 \\
\hline U-112 & SW Corner & 1969 & 32,000 \\
\hline
\end{tabular}

The 216-U-13 trench, located immediately west of the tank farm fence (see Figure 2.1), was used for steam cleaning and decontaminating vehicles and never received tank waste. Contaminated soil was removed from the trench and backfilled with clean fill (DOE 1992).

\subsection{Waste Characteristics}

A description of wastes sent to the $U$ tank farm is presented in Hodges and Chou (2000), but Table 2.2 is repeated here to document the chemicals and radionuclides present in the WMA. Table 2.2 presents average concentrations for selected components in the waste at WMA $U$ and ratios of their concentrations to drinking water standards or maximum contaminant levels. These unweighted averages represent bulk tank concentrations and do not distinguish between liquid and solid phases within the tanks and, therefore should be used only as a gross indication of tank concentrations. Considerable effort has been expanded over the past 5 years to develop best-basis inventory estimates for the contents of all 177 Hanford waste tanks. Table 2.2 presents the constituents that could appear in the groundwater from an impact attributable to the WMA. Major chemical species include sodium, chromium, nitrate, sulfate, chloride, and fluoride. Nitrite and ammonium are present in the tanks in significant quantities, but they are rarely detected in Hanford Site groundwater because they are probably converted to nitrate by bacterial action. Nitrite has only rarely been detected in samples collected in WMA U.

Some of the tanks also contain significant quantities of organic complexants used during plutonium separations operations. These compounds are mobile and may be co-contaminants in wastes originating from the tanks.

In addition to the chemical constituents, the tank waste contains a wide variety of radioactive constituents, including cesium-137, strontium-90, cobalt-60, tritium, technetium-99, iodine-129, selenium-79, and neptunium-237, along with several isotopes of uranium and plutonium. From the perspective of transport, the most important radioactive indicators of groundwater contamination for the WMA are tritium, technetium-99, and iodine-129. 
Table 2.2. Selected Waste Constituents in Tanks at Waste Management Area U (Hodges and Chou 2000)

\begin{tabular}{|c|c|c|}
\hline Waste Component & $\begin{array}{l}\text { Average Concentration } \\
\text { in the Tanks }\end{array}$ & $\begin{array}{c}\text { Concentration Divided by } \\
\text { DWS or MCL }\end{array}$ \\
\hline Sodium & $1.5 \times 10^{8} \mu \mathrm{g} / \mathrm{L}$ & (a) \\
\hline Calcium & $1.6 \times 10^{6} \mu \mathrm{g} / \mathrm{L}$ & (a) \\
\hline Chromium & $2.6 \times 10^{6} \mu \mathrm{g} / \mathrm{L}$ & 26,000 \\
\hline Nitrate & $1.4 \times 10^{8} \mu \mathrm{g} / \mathrm{L}$ & 3,111 \\
\hline Nitrite & $4.46 \times 10^{7} \mu \mathrm{g} / \mathrm{L}$ & 13,500 \\
\hline Ammonium & $6.68 \times 10^{5} \mu \mathrm{g} / \mathrm{L}$ & (a) \\
\hline Sulfate & $1.7 \times 10^{7} \mu \mathrm{g} / \mathrm{L}$ & 34 \\
\hline Chloride & $3.0 \times 10^{6} \mu \mathrm{g} / \mathrm{L}$ & (a) \\
\hline Fluoride & $6.2 \times 10^{5} \mu \mathrm{g} / \mathrm{L}$ & 155 \\
\hline Phosphate & $1.3 \times 10^{7} \mu \mathrm{g} / \mathrm{L}$ & (a) \\
\hline Carbon-14 & $2.02 \times 10^{7} \mathrm{pCi} / \mathrm{L}$ & 10,100 \\
\hline Cesium-137 & $1.59 \times 10^{11} \mathrm{pCi} / \mathrm{L}$ & $795,000,000$ \\
\hline Strontium-90 & $7.83 \times 10^{10} \mathrm{pCi} / \mathrm{L}$ & $9,790,000,000$ \\
\hline Tritium & $1.4 \times 10^{8} \mathrm{pCi} / \mathrm{L}$ & 7,000 \\
\hline Cobalt- 60 & $2.2 \times 10^{7} \mathrm{pCi} / \mathrm{L}$ & 220,000 \\
\hline Technetium-99 & $1.4 \times 10^{8} \mathrm{pCi} / \mathrm{L}$ & 155,555 \\
\hline Selenium-79 & $2.01 \times 10^{6} \mathrm{pCi} / \mathrm{L}$ & (a) \\
\hline Iodine-129 & $2.7 \times 10^{5} \mathrm{pCi} / \mathrm{L}$ & 270,000 \\
\hline Uranium-232 & $4.15 \times 10^{5} \mathrm{pCi} / \mathrm{L}$ & (a) \\
\hline Uranium-233 & $1.59 \times 10^{6} \mathrm{pCi} / \mathrm{L}$ & (a) \\
\hline Uranium-234 & $2.05 \times 10^{7} \mathrm{pCi} / \mathrm{L}$ & (a) \\
\hline Uranium-235 & $9.1 \times 10^{5} \mathrm{pCi} / \mathrm{L}$ & (a) \\
\hline Uranium-236 & $2.02 \times 10^{5} \mathrm{pCi} / \mathrm{L}$ & (a) \\
\hline Uranium-238 & $2.06 \times 10^{7} \mathrm{pCi} / \mathrm{L}$ & (a) \\
\hline Uranium & $2.52 \times 10^{5} \mu \mathrm{g} / \mathrm{L}$ & 12,600 \\
\hline Neptunium-237 & $5.19 \times 10^{5} \mathrm{pCi} / \mathrm{L}$ & 34,600 \\
\hline Plutonium-238 & $6.71 \times 10^{6} \mathrm{pCi} / \mathrm{L}$ & 44,700 \\
\hline Plutonium-239 & $3.85 \times 10^{8} \mathrm{pCi} / \mathrm{L}$ & $25,700,000$ \\
\hline Plutonium-240 & $5.52 \times 10^{7} \mathrm{pCi} / \mathrm{L}$ & $3,680,000$ \\
\hline Plutonium-241 & $3.72 \times 10^{8} \mathrm{pCi} / \mathrm{L}$ & $24,800,000$ \\
\hline Plutonium-242 & $1.6 \times 10^{3} \mathrm{pCi} / \mathrm{L}$ & 107 \\
\hline Americium-241 & $3.4 \times 10^{6} \mathrm{pCi} / \mathrm{L}$ & 227,000 \\
\hline Americium-243 & $3.92 \times 10^{3} \mathrm{pCi} / \mathrm{L}$ & 261 \\
\hline Curium-242 & $3.14 \times 10^{5} \mathrm{pCi} / \mathrm{L}$ & 20,900 \\
\hline Curium-243 & $1.33 \times 10^{4} \mathrm{pCi} / \mathrm{L}$ & 887 \\
\hline Curium-244 & $1.78 \times 10^{5} \mathrm{pCi} / \mathrm{L}$ & 11,900 \\
\hline
\end{tabular}




\subsection{Geology}

The geologic materials beneath the WMA play an important role in this plan by serving as a secondary source from contamination leaked to ground as well as influencing where and how contaminants move through the vadose and saturated groundwater zones. In general in 200 West Area, the Elephant Mountain Member of the Saddle Mountains Basalt, Columbia River Basalt Group serves as the base of the unconfined aquifer (Reidel and Fecht 1981). The unconfined aquifer is located in the Ringold Formation. The Hanford formation (informal name) sedimentary sequence overlies the Ringold Formation and extends to ground surface. For a detailed geographic and geologic description of the stratigraphic units present in the 200 West Area, see Lindsey et al. (1992). Additional discussions of the geology beneath WMA U specifically are found in Price and Fecht (1976).

WMA U is situated in the south central portion of the 200 West Area where specific sedimentary strata influence contaminant migration pathways in significant ways. Two geologic cross sections are shown in Figures 2.2 and 2.3. Figure 2.4 is a location map showing where the cross-sections are located. Plate 1 in the back of the report provides a more complete description of the geology summarized in Figures 2.2 and 2.3. The suprabasalt sediments that compose the uppermost aquifer system are approximately $170 \mathrm{~m}$ thick and lie on the surface of the Elephant Mountain Basalt bedrock, which dips to the south-southwest beneath WMA U. Ringold Unit 9 lies directly on top of the basalt and is up to $30 \mathrm{~m}$ thick. This unit is composed of sand and gravel and dips to the south-southwest. The Ringold Unit 8 (Lower mud unit) confining interval lies on top of Ringold Unit 9 approximately $140 \mathrm{~m}$ below ground surface and averages over $15 \mathrm{~m}$ thick. The hydraulic conductivity of this unit is low, estimated at less than $10^{-6} \mathrm{~m} / \mathrm{d}$ (Bergeron and Wurstner 2000); therefore, it effectively serves as the base of the upper aquifer. Ringold Unit 8 also dips to the south-southwest beneath the tank farm. The uppermost aquifer, approximately $65 \mathrm{~m}$ thick beneath WMA U, is entirely within the Ringold Unit 5 (Ringold Unit E) gravel, which lies on top of Ringold Unit 8.

Ringold Unit 5 gravel is best described as fluvial sandy gravel ranging from sand to silty sandy gravel and cobble gravel. Gravels are generally clast supported. Drill cuttings, drill rate, and geophysical logs easily identify the Ringold Unit 5 gravel. The top of Unit 5 is above the water table and drops approximately $3 \mathrm{~m}$ to the south-southwest beneath the tank farm. The Upper Ringold Unit (Unit 4) is not present beneath the tank farm based on a review of drilling, geologic, and geophysical logs. The fine-grained Plio-Pleistocene interval overlies Ringold Unit 5.

Above the water table, the vadose zone is composed in ascending order of the upper Ringold Unit 5 silty sandy gravel, which is unconformably overlain by the Plio-Pleistocene interval composed of sandy silt to clay and includes a basal carbonate cemented soil horizon (caliche zone), and finally the Hanford silt, sand, and gravel. The vadose zone is approximately $67 \mathrm{~m}$ thick.

The Plio-Pleistocene interval is composed of two distinct intervals that may affect infiltration of tank leaks and other liquids: 1) a basal soil horizon (caliche zone) that developed on the exposed paleo-surface of the Ringold Formation, and 2) a thicker fine sand/silt unit above. The caliche zone is composed of calcium carbonate cemented sand, silt, and/or Ringold gravel. Cementation varies from finely disseminated carbonate particles in the silt to calcium carbonate nodules in the fine sands. Within the gravel the 
U TANK FARM AREA STRUCTURAL CROSS-SECTION A-A

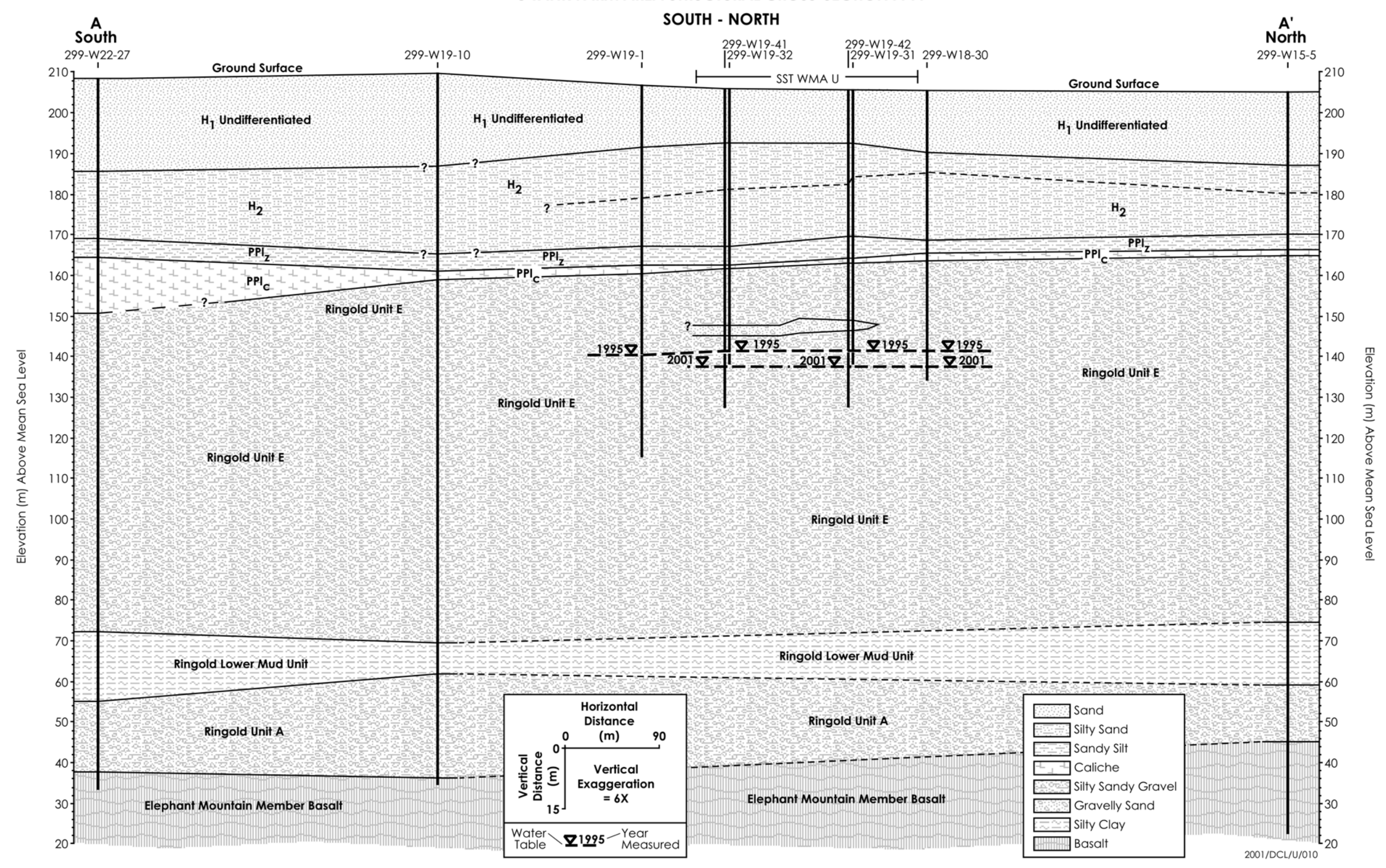

Figure 2.2. North-South Geologic Cross-Section 


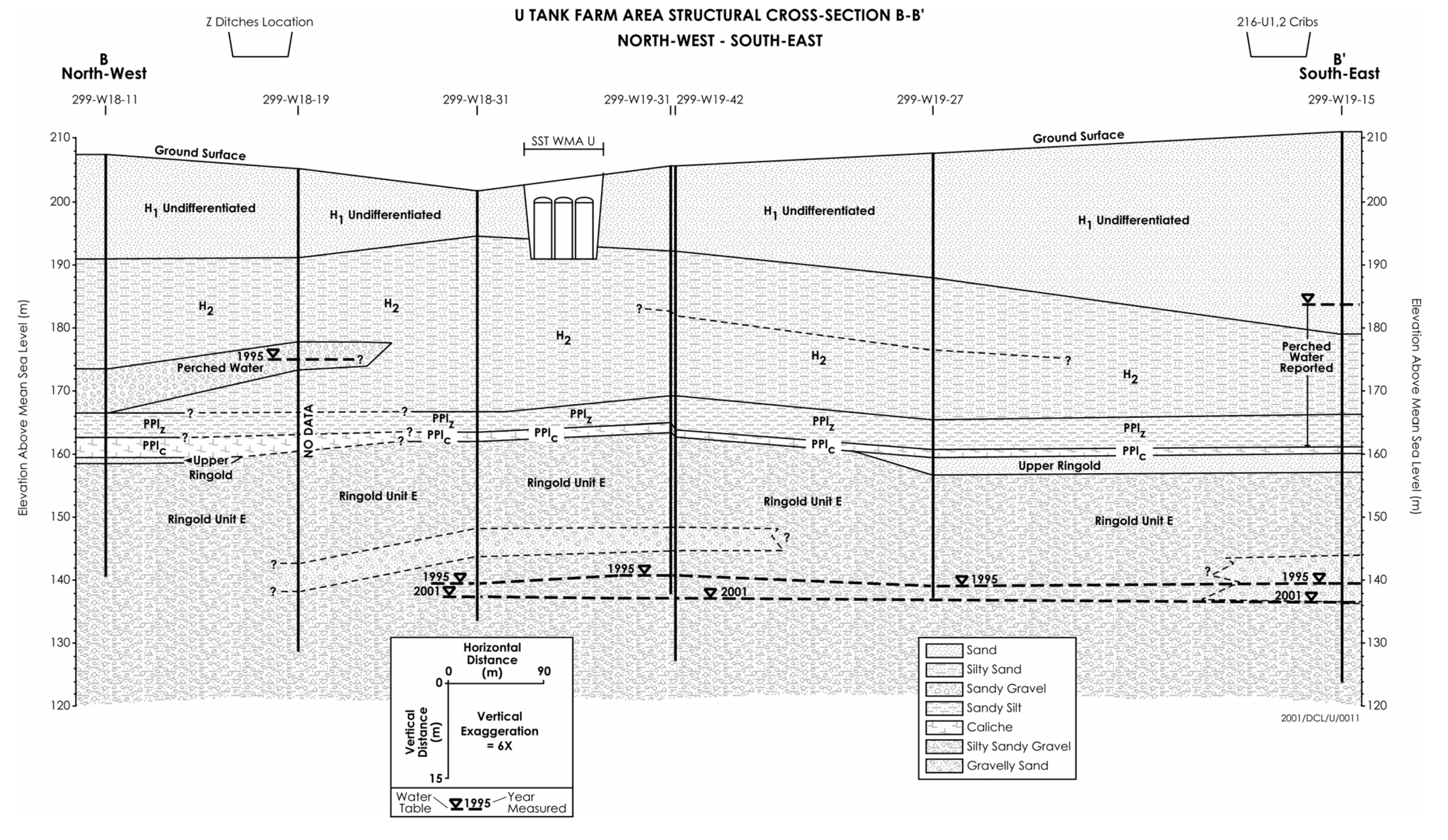

Figure 2.3. East-West Geologic Cross-Section 


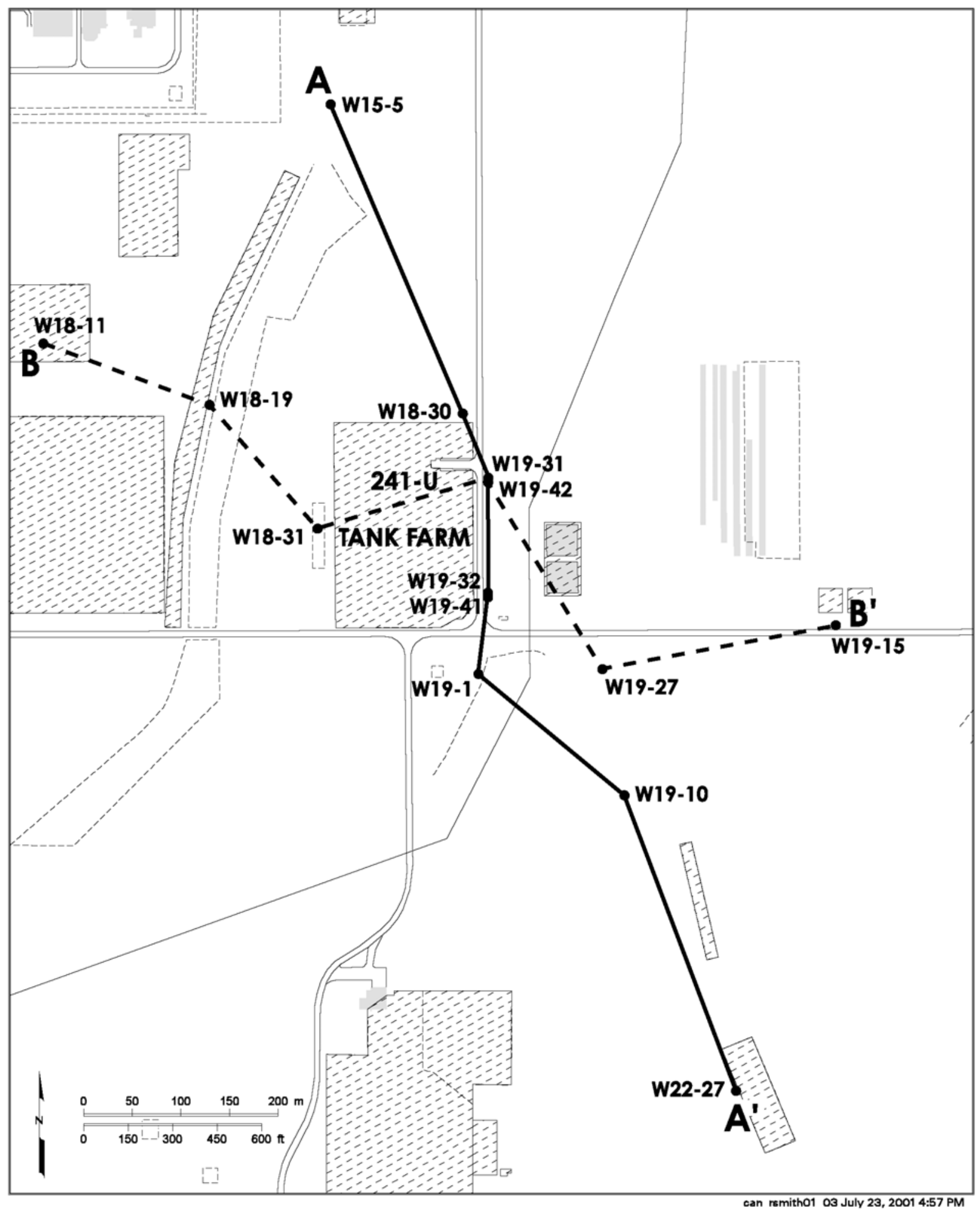

Figure 2.4. Water Table in the Vicinity of Waste Management Area U, March 2001 
caliche exhibits variable matrix cementation that can form hard solid white to pale white stringers or layers. Root casts and weathered sediments have also been identified (elsewhere) within this interval. The top of the caliche zone dips approximately $3 \mathrm{~m}$ to the south-southwest beneath the tank farm similar to the Ringold Formation Unit 5. The caliche grades downward into unaltered, un-weathered Ringold Unit 5 gravel, which can be distinguished from the weathered gravel by the lack of carbonate reaction to dilute hydrochloric acid. The caliche zone averages approximately $1 \mathrm{~m}$ thick.

Above the caliche zone, the Plio-Pleistocene is composed of mostly very fine sandy silt to silt/clay that exhibits very little depositional structure (i.e., massive) in core samples and, therefore, has been interpreted to be eolian in origin. This interval dips 2.5 to $3 \mathrm{~m}$ to the southwest similar to the Ringold Unit 5 and ranges from 3 to $6 \mathrm{~m}$ thick beneath WMA U. The Plio-Pleistocene interval is an areally extensive zone beneath most of the 200 West Area where conditions of perched water have been noted. Locally, liquid effluent discharged at the $Z$ ditches to the west and the U-14 Ditch and U1/2 Cribs to the east, has perched above this interval. These observations indicate that water percolating through the vadose zone beneath the WMA may move to the south-southwest along the top of the Plio-Pleistocene interval.

The Hanford formation (Unit 1) overlies the Plio-Pleistocene interval and can be separated into two depositional intervals: 1) the lower $\mathrm{H} 2$ unit composed of mostly sand and silt, and 2) the H1 unit, which is composed of higher-energy deposits consisting of coarse-grained sand to gravel. The contact between the $\mathrm{H} 1$ and $\mathrm{H} 2$ units is gradational and irregular and slopes to the east-northeast, unlike the older formations beneath the Hanford formation that all dip to the southwest. The H1-H2 contact drops approximately $3 \mathrm{~m}$ to the northeast across WMA U. The $\mathrm{H} 2$ unit averages $24 \mathrm{~m}$ thick, thinning to the northeast and east. The slope of this unit most likely was shaped and controlled by higher-energy flood deposits as a facies transition as indicated by the accumulation of coarser-grained sediments above it. The H2 unit is composed of stacked, repeating, flat lying sequences of silt and fine sand lamina. These thin-bedded intervals can be differentiated only by intact sediment core evaluation. The H2 typically is a fining downward sequence based on core analysis and geophysical log interpretations. The only notable change in the $\mathrm{H} 2$ unit is a gravelly sand lens that develops in wells just west of the tank farm near the $\mathrm{Z}$ ditches. The gravel does not exist beneath the tank farm but records indicate that infiltrating water from the $Z$ ditches at one time saturated the upper $\mathrm{H} 2$ unit and this gravel interval. The eastern extent of this gravelly interval has not been determined because it does not exist in wells beneath or surrounding the tank farm.

The base of the tanks is within the $\mathrm{H} 1$ unit, near the $\mathrm{H} 1-\mathrm{H} 2$ boundary, therefore, the migration of water and waste liquids from within the tank farm is controlled within the vadose zone by this contact, the Plio-Pleistocene unit, and Ringold Unit 5. With the exception of the H1-H2 contact, these units slope to the south-southwest; therefore, it is probable that leaking tank liquids could migrate laterally to the southwest along the older, lower sedimentary interfaces.

The upper $\mathrm{H} 1$ unit is differentiated from the $\mathrm{H} 2$ unit primarily by grain size; a significant change in overall grain size occurs at the $\mathrm{H} 1-\mathrm{H} 2$ boundary, from a uniformly coarser sand and gravel above to finergrained sand and silt of the $\mathrm{H} 2$ unit below. Within the H1, sediments may be composed of coarse sand to silty sandy gravel, and clean clast-supported (open framework) gravel. The H1 interval is considered the most permeable unit in the suprabasalt sequence because of the lack of cementation and its well-sorted 
and clast-supported nature. The $\mathrm{H} 1 \mathrm{unit}$ is approximately 12 to $15 \mathrm{~m}$ thick. Most cribs and ditches in the area surrounding the tank farm that have released liquids to the ground are constructed within this very permeable interval. Overlying the Hanford $\mathrm{H} 1$ unit is a thin veneer (1 to $3 \mathrm{~m}$ ) of recently deposited eolian silt and sand.

\subsection{Hydrology}

Water beneath the WMA is found in the unsaturated vadose zone above the water table and in the saturated zone below the water table. Properties of groundwater in both regions are important in understanding how the WMA may impact groundwater quality. Generally, groundwater refers to water below the water table and this convention will be used in this plan.

\subsubsection{Vadose Zone Hydrology}

The unsaturated sediments above the water table affect how waste solutions move through the soil, how much is retained in the sediment column, and how much waste eventually reaches the water table. The source of contamination for the WMA is liquid waste released to near surface or subsurface sediments. These liquids move through the sediment under unsaturated conditions and as a result, tend to spread laterally at changes in stratigraphy. Small volume leaks would tend to be retained in the vadose zone near the leak point. Larger leaks would be expected to move deeper in the soil, spreading laterally as the wetting front moves downward.

A major stratigraphic change is the top of the Plio-Pleistocene unit. This unit, located about $30 \mathrm{~m}$ below ground surface would slow the downward movement of water and divert it to the southwest, the direction the top of the unit is dipping beneath the WMA. Water from a waste release may reach the water table at a time, location, and concentration depending on its volume, depth of release, and diversion from downward movement at a stratigraphic change. Over time, wastewater released to the sediment column near ground surface will evaporate or be driven downward to the water table by new inputs of water to the sediment column from above. It is this downward movement of water in the vadose zone that carries waste contaminants to the water table. Water movement in the unsaturated zone is relatively slow compared to groundwater flow below the water table, delaying the observed impact of a near surface waste release on groundwater quality.

\subsubsection{Saturated Zone Hydrology}

Properties of the groundwater system determine where contaminants are transported, how widely they spread and their resultant concentrations, and how fast they move away from the WMA. Groundwater characteristics important for this plan are the direction of groundwater flow in three dimensions and the flow rate. These properties may be determined several ways, but the standard method for this WMA has been to measure water levels in surrounding monitoring wells. A depiction of the water table surface in March 2001 is presented as a water table map in Figure 2.5. 


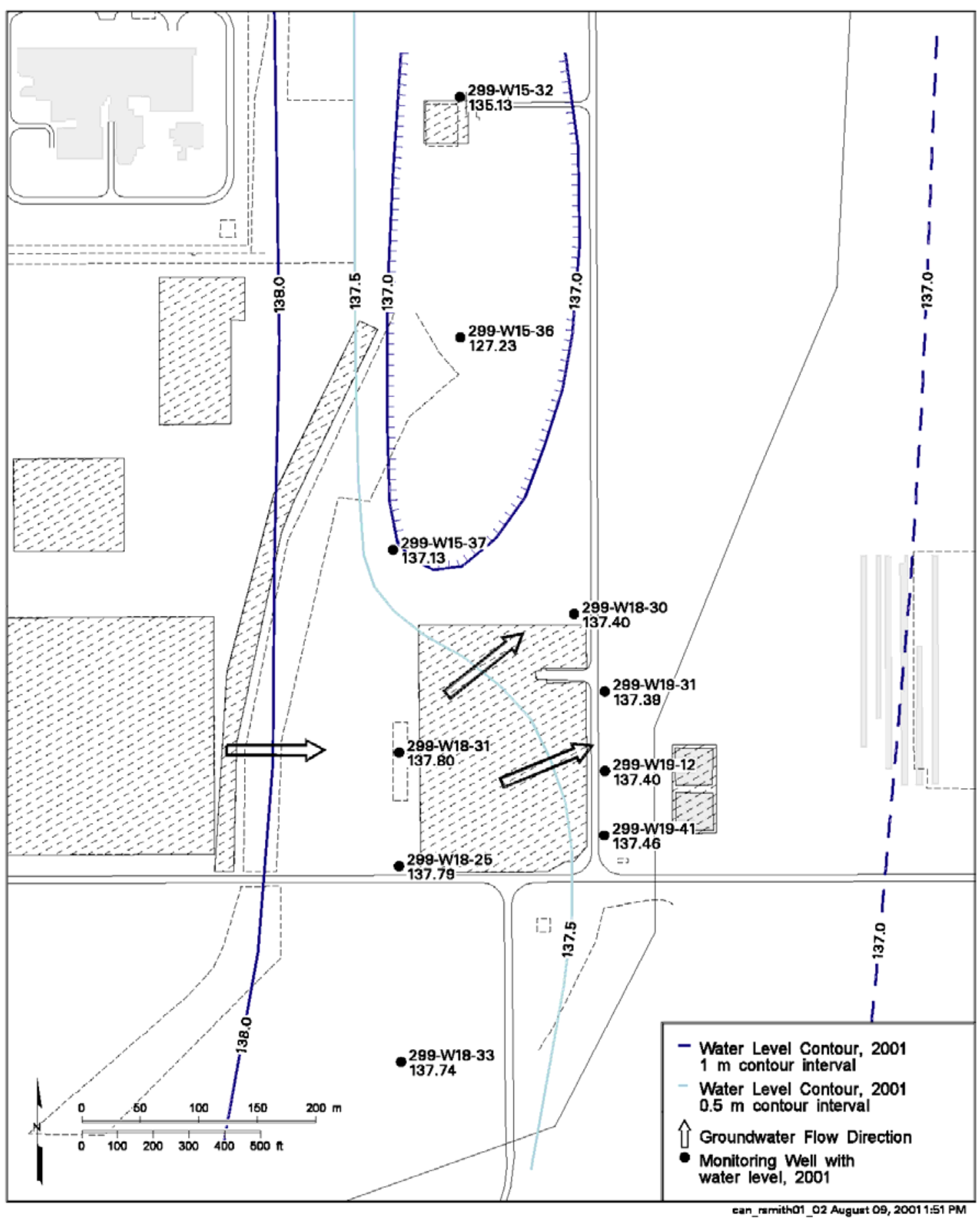

Figure 2.5. Water Table in the Vicinity of Waste Management Area U, March 2001 
Groundwater flow direction and hydraulic gradient across WMA U were also determined by performing a trend surface analysis of water level measurements in surrounding monitoring wells. An analysis of these data is presented in the letter report provided in Appendix $\mathrm{A}^{\text {(a) }}$. Three combinations were evaluated: 1) the WMA as a whole, 2) the northern WMA, and 3) the southern WMA. In summary, the hydraulic gradient has remained constant at approximately 0.0021 and consistently easterly groundwater flow direction is indicated (Tables 2, 3, and 4, Appendix A).

Groundwater flow velocity, v, has been estimated using the Darcy equation:

$$
\mathrm{v}=-\mathrm{Ki} / \mathrm{n}_{\mathrm{e}}
$$

where $\mathrm{K}=$ hydraulic conductivity

$\mathrm{i}=$ hydraulic gradient

$\mathrm{n}_{\mathrm{e}}=$ effective porosity

Values for hydraulic conductivity and effective porosity have been determined from various aquifer tests including slug tests, constant-rate pumping tests, and tracer-dilution tests. A description of these tests and their results are presented in Spane et al. (2001). These tests indicated that the hydraulic conductivity and effective porosity (specific yield) for the area around well 299-W19-42 are $6.12 \mathrm{~m} / \mathrm{d}$ and 0.17. Hydraulic conductivity determined from slug tests at well $299-\mathrm{W} 19-41$ ranged from $1.1 \mathrm{~m} / \mathrm{d}$ to $1.9 \mathrm{~m} / \mathrm{d}$, but, according to Spane et al. (2001), the test responses indicated that the well was probably not fully developed, which may explain why the hydraulic conductivity was lower than in well 299-W19-42. Using the data from well 299-W19-42, the groundwater flow velocity is calculated to be about $30 \mathrm{~m} / \mathrm{yr}$.

Over time, groundwater flow direction and velocity may change in response to dewatering of the unconfined aquifer beneath the WMA. The aquifer, which was artificially recharged by Hanford operations resulting in a rise in the water table, is no longer receiving large volumes of water and the excess water is draining from the aquifer. The resultant falling water table may change the groundwater flow direction and cause the hydraulic gradient to decrease. Hydrographs for WMA U groundwater monitoring wells are shown in Figure 2.6. The water table has been dropping at a linear rate of about $0.4 \mathrm{~m} / \mathrm{yr}$ since 1998. Since 1997, water levels in upgradient and downgradient wells have separated into two populations indicating a distinct gradient across the WMA.

Previous interpretations of water levels in an area north of WMA U indicated that groundwater withdrawals from a nearby pumping well 299-W15-37, part of the ZP-1 Operable Unit pump-and-treat remedial action, caused groundwater in the northern half of WMA U to be diverted to the north-northeast direction from the generally easterly flow direction. Because the well is about $100 \mathrm{~m}$ from the northern boundary of the WMA, the well was thought to have diverted groundwater flow even though there were no wells between the pumping well and the north end of the WMA to support this assumption. Pumping of the well was permanently discontinued on January 17,2001. Before the pumping well was to be shut down, pressure transducers and data loggers were placed on two WMA U monitoring wells to record any impact on water levels. In addition, weekly water level measurements in wells surrounding the WMA

(a) F. A. Spane, letter report to R. M. Smith, March 14, 2001. 


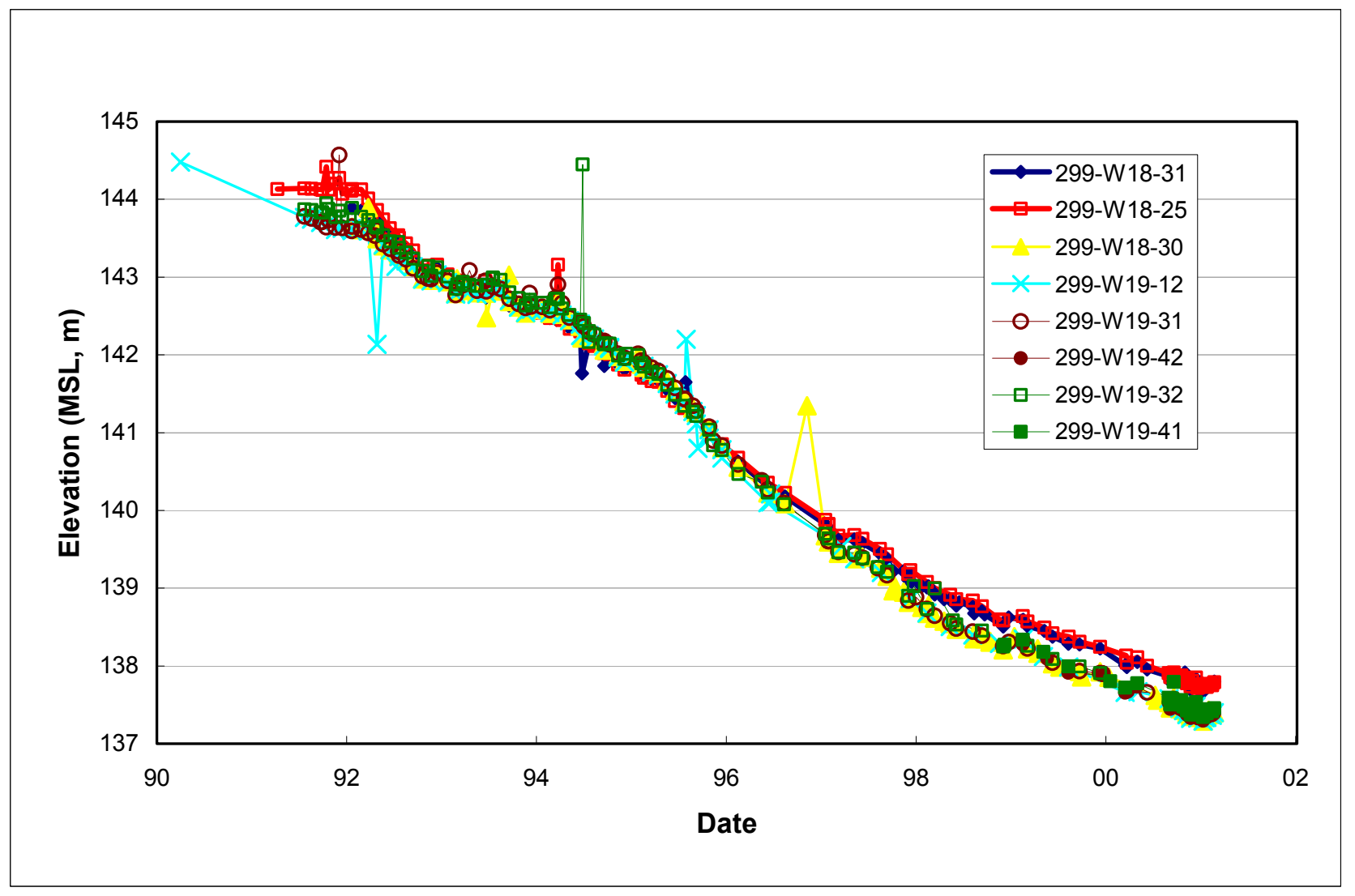

Figure 2.6. Hydrographs for Groundwater Monitoring Wells at Waste Management Area U

were started. The letter report presented in Appendix A provides a detailed analysis of water levels and groundwater flow before and after well 299-W15-37 was removed from the remedial action. Figure 2 in Appendix A shows the manually measured water levels for six monitoring wells around WMA U. This figure shows that water levels in all of the wells responded similarly; therefore, pumping at well 299-W15-37 has affected all of the wells equally. Spane (Appendix A) evaluated the effects of shutting down pumping well 299-W15-37 and concluded that water levels were affected in the two wells monitored, 299-W18-31 and 299-W19-42, but only by up to $0.1 \mathrm{~m}$. Because atmospheric changes affected water levels by up to $0.25 \mathrm{~m}$ over a several day period, the effect of the pumping well could be determined only by removing barometric effects. Continued monitoring indicated that the rising water levels (recovery period) lasted only 1 month, at which time, water levels began to drop at the rate of the regional water table in 200 West Area of about $0.4 \mathrm{~m} / \mathrm{yr}$. Therefore, contrary to previous interpretations, while pumping well 299-W15-37 did have an impact on groundwater in the vicinity of WMA U, that effect was apparently equal across the entire area and negligible in its effect on groundwater flow direction and velocity.

The falling water table affects the regional hydraulic gradient and groundwater flow rate and also shortens the useful lifetime of monitoring wells. The water table will reach steady-state levels when it reaches pre-Hanford levels or some other level based on current and future aquifer recharge scenarios. 
Kipp and Mudd (1974) presented a water table map for the Hanford Site in 1944, prior to Hanford operations, which was based on water levels estimated from data collected between 1948 and 1952. The estimated water table elevation in the vicinity of WMA U was about $124 \mathrm{~m}$ above sea level and is the assumed base level to which the water table could fall. The 1944 estimated water table elevation for 200 West Area may be low, indicated by later maps showing the water table $3 \mathrm{~m}$ to $6 \mathrm{~m}$ higher in areas unaffected by Hanford operations. Bergeron and Wurstner (2000) predicted post-Hanford steady-state water levels using a three-dimensional groundwater flow model of the Hanford Site. The predicted steady-state water level elevation for the WMA U area is about $130 \mathrm{~m}$. These water levels, the current water table position, and the screened intervals for the current monitoring wells are presented on Figure 2.7. The figure shows how much screened interval is currently available for groundwater monitoring and where the bottom of the screened interval is located relative to possible future baseline water levels.

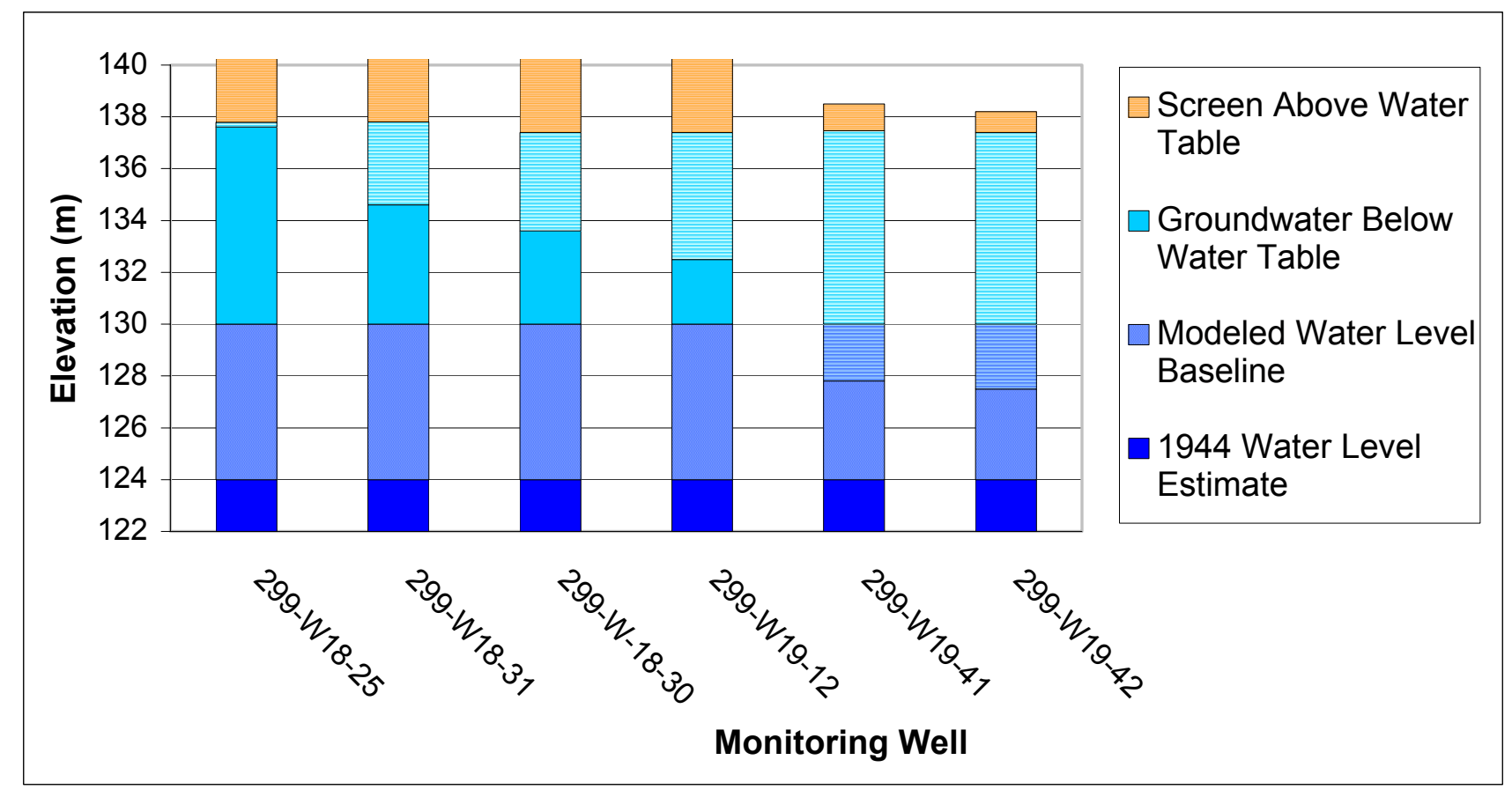

Figure 2.7. Screened Interval Relative to Current and Future Water Levels

Upgradient well 299-W18-25 had about $0.2 \mathrm{~m}$ of water above the screen bottom; too little to sample and it will be completely dry within 6 months. With the water table falling at a rate of $0.4 \mathrm{~m} / \mathrm{yr}$, the next well that will become unsampleable is well 299-W18-31 in about 6 years. Well 299-W18-30 has an estimated lifetime of about 8 years. The other wells and the new wells will likely have a lifetime that is independent of water levels unless the baseline water level drops to the 1944 predicted level. Conservatively, those wells have a minimum lifetime, based on water levels, of about 25 years. 


\subsection{Vadose Zone Contamination}

Contaminants that reach the water table must pass through the vadose zone where plumes from past leaks and spills have been retained or their movement slowed by either chemical (sorption) or physical (water retention under unsaturated conditions) processes. Knowing the location of current vadose zone contamination provides a basis for focusing groundwater monitoring on a specific area of the WMA or providing an explanation for groundwater contamination if it is detected. Spectral gamma logging in boreholes drilled around tanks in the WMA has been conducted to delineate where gamma emitting radionuclides are located in the vadose zone (DOE 2000). While the radioactive contaminants detectable by gamma logging are considered fairly immobile in Hanford sediments, the vadose zone plumes identified indicate where more mobile tank constituents have been released to the soil and provide a minimum indication of how deep the plumes may have migrated.

Figures 2.8 and 2.9 contain selected figures from the addendum to the $\mathrm{U}$ tank farm spectral gamma logging report (DOE 2000). These figures present the authors' spatial representation of the spectral gamma logs collected for each drywell and are used in this report to indicate the general locations of gamma contamination around the tanks. The gamma logs, which present the actual data, are included in the logging report (DOE 2000). The addendum and the original report can be viewed at http://www. doegjpo.com/programs/hanf/HTFVZ.html.

Figure 2.8 presents a general representation of detected contamination at progressively deeper positions beneath ground surface ranging from $1.2 \mathrm{~m}$ to $30.5 \mathrm{~m}$ deep. This figure generally indicates that contaminated sediments are located mainly near ground surface and at and just below the bottom of the tanks. Approximately $50 \%$ of the near surface sediments ( $1.2 \mathrm{~m}$ below ground) appear to be contaminated as shown in Figure 2.8a. At $7 \mathrm{~m}$ deep, just above the bottom of the tanks, Figure 2.8b indicates that only one borehole adjacent to tank U-110 contained significant gamma contamination. Figure $2.8 \mathrm{c}$ shows that at $17 \mathrm{~m}$, approximately $6 \mathrm{~m}$ below the bottom of the tanks, uranium and cesium spread from each of the reported leaking tanks except for tank U-101. Subsurface contamination appears to be the most widespread at this depth indicating that most of the deep contamination was from tank leaks and that it was retained close to the bottoms of the tanks. The uranium distribution suggests that liquids leaked from tank U-104 may have spread to the southwest. At $30.5 \mathrm{~m}$, only one borehole contained measurable amounts of cesium contamination. Figure 2.9 shows four, three-dimensional views of vadose zone contamination. These figures indicate that liquid wastes leaked to the sediments tended to spread at a depth that is near the contact between the $\mathrm{H} 1$ and $\mathrm{H} 2$ units in the Hanford formation. This effect can be observed most easily in Figure $2.9 \mathrm{~b}$ where the shape of the cesium plume beneath tank U-110 and the uranium plume beside tank U-111 appear flattened. The maximum depth of cesium detection beneath tank U-112 appears to coincide with the top of the Plio-Pleistocene interval. These relationships warrant additional attention when the WMA is investigated for closure purposes.

These spectral gamma data indicate that near surface sediments are extensively contaminated, but this contamination has remained near the surface. The source of this contamination is likely spills and unplanned releases and not the tanks. Deeper contamination appears to be associated with tank leaks that spread laterally at the bottom of the tanks. It appears that some of the contamination also spread laterally 


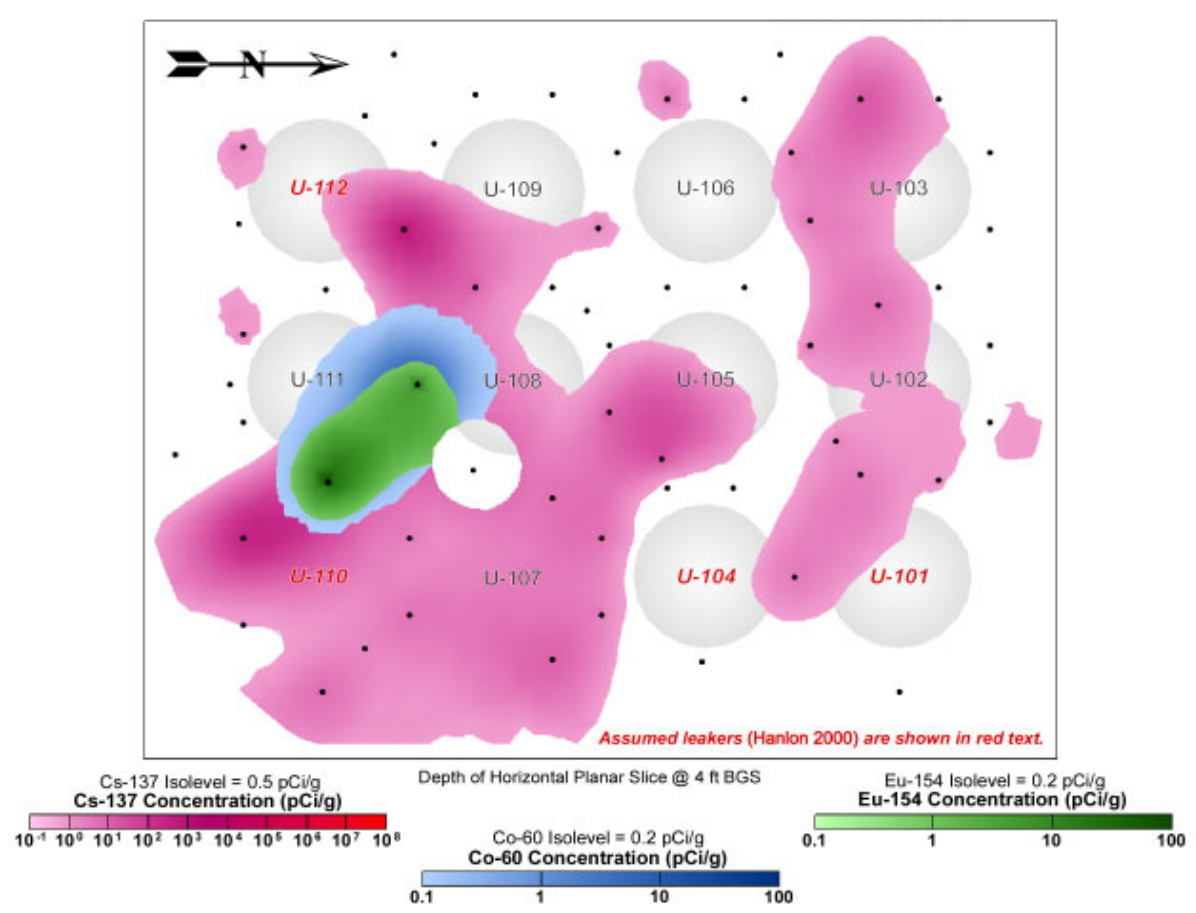

(a)

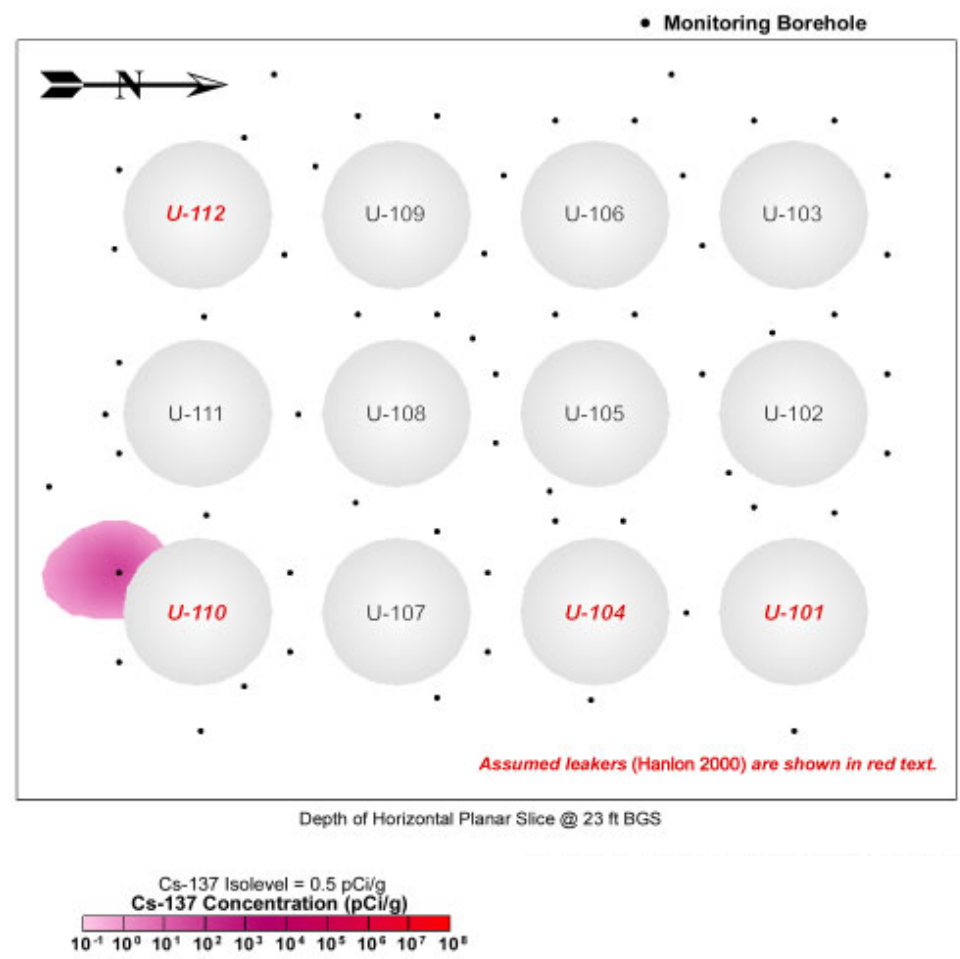

(b)

Figure 2.8. Distribution of Gamma Emitting Radionuclides at Various Depths in Waste Management Area U (from DOE 2000) 


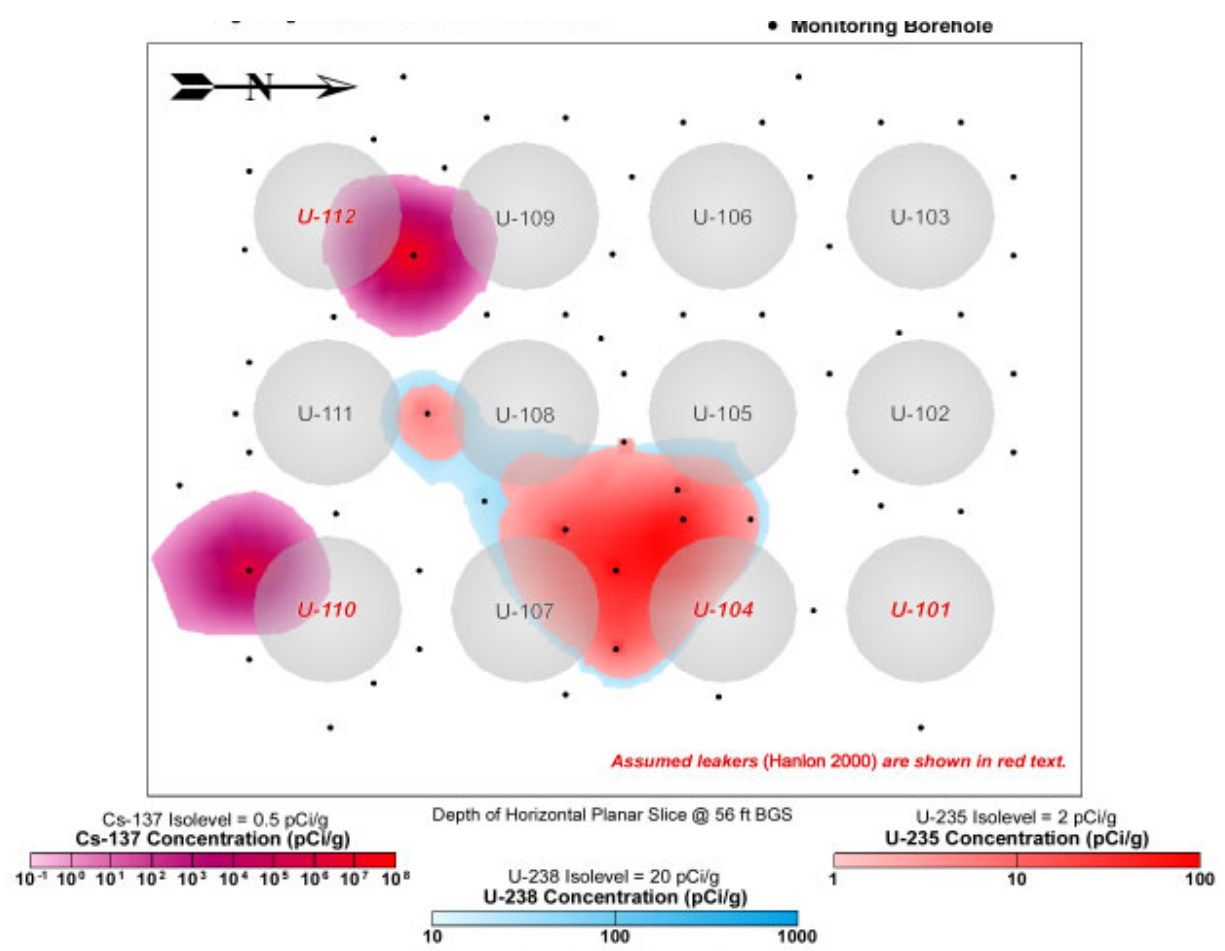

(c)

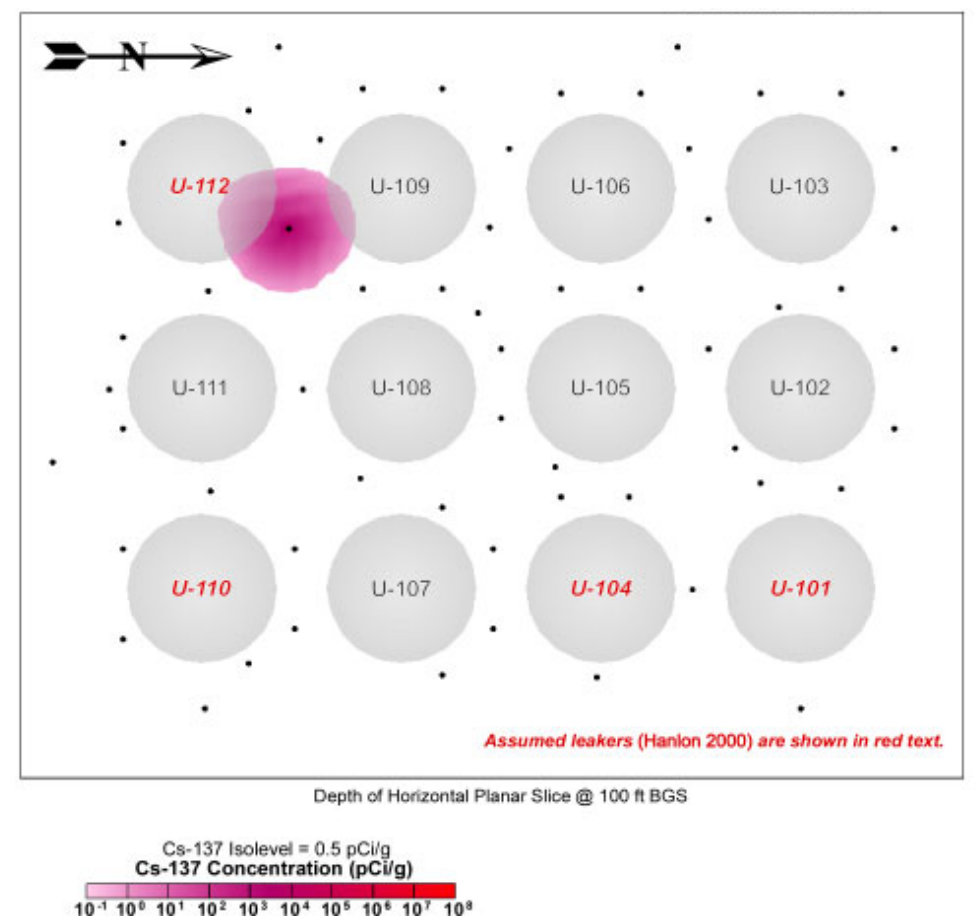

(d)

Figure 2.8. Distribution of Gamma Emitting Radionuclides at Various Depths in Waste Waste Management Area (from DOE 2000) (continued) 


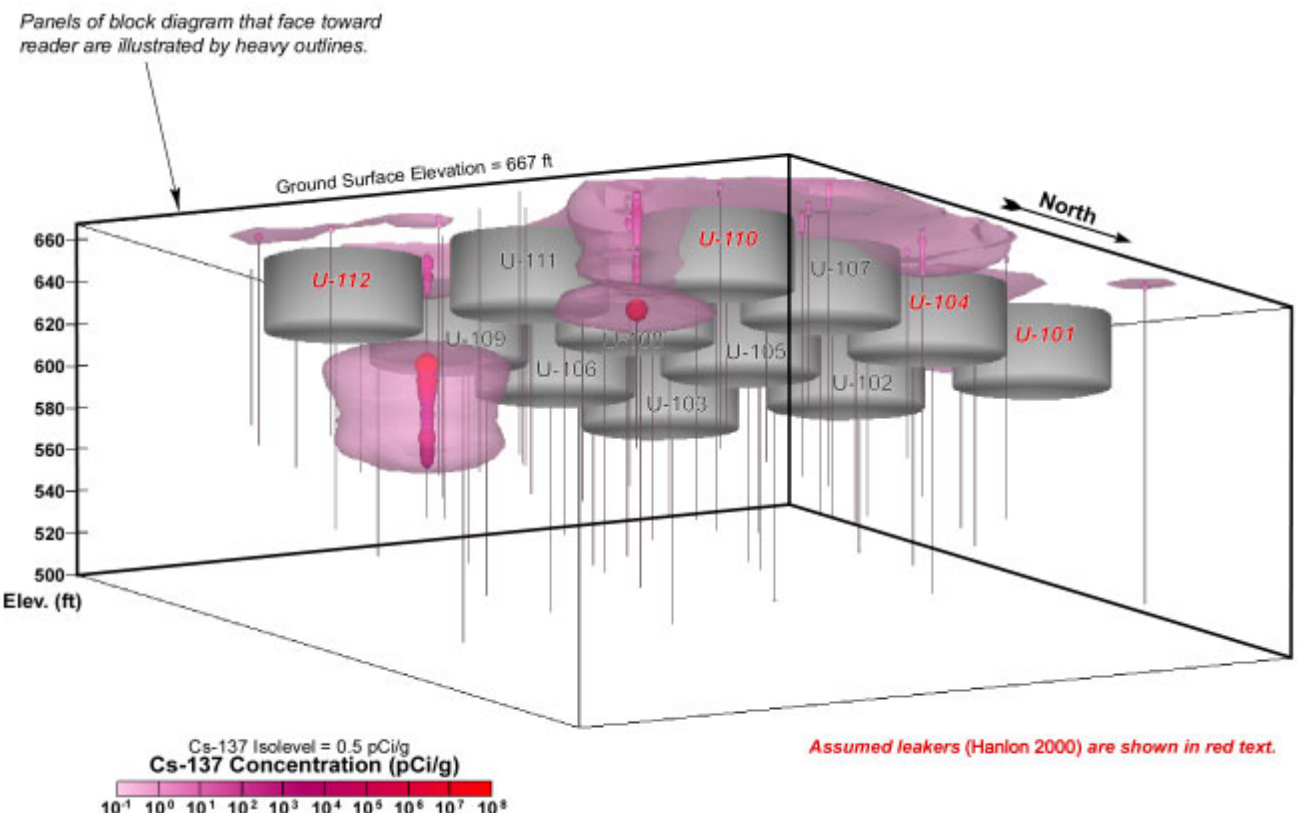

(a)

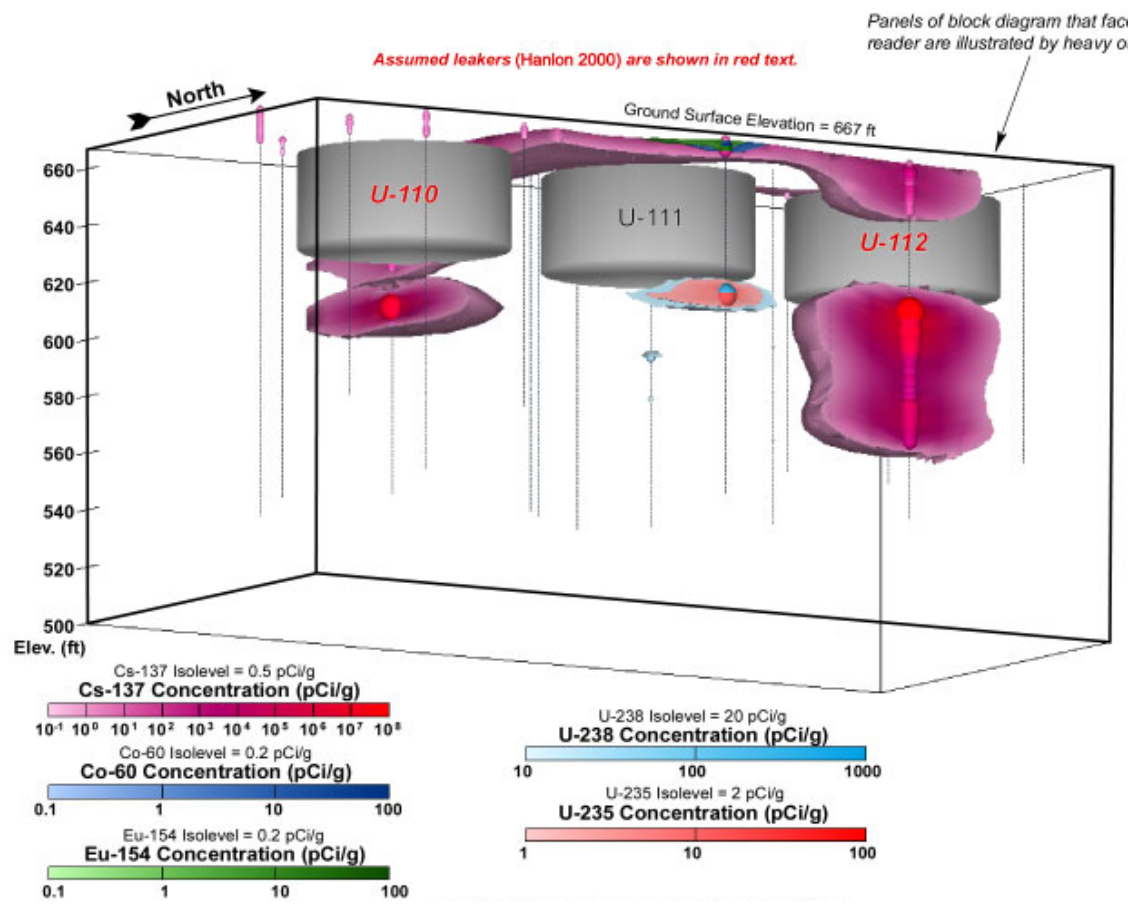

(b)

Figure 2.9. Three-Dimensional Distribution of Gamma Radionuclides Beneath Waste Management Area U (from DOE 2000) 


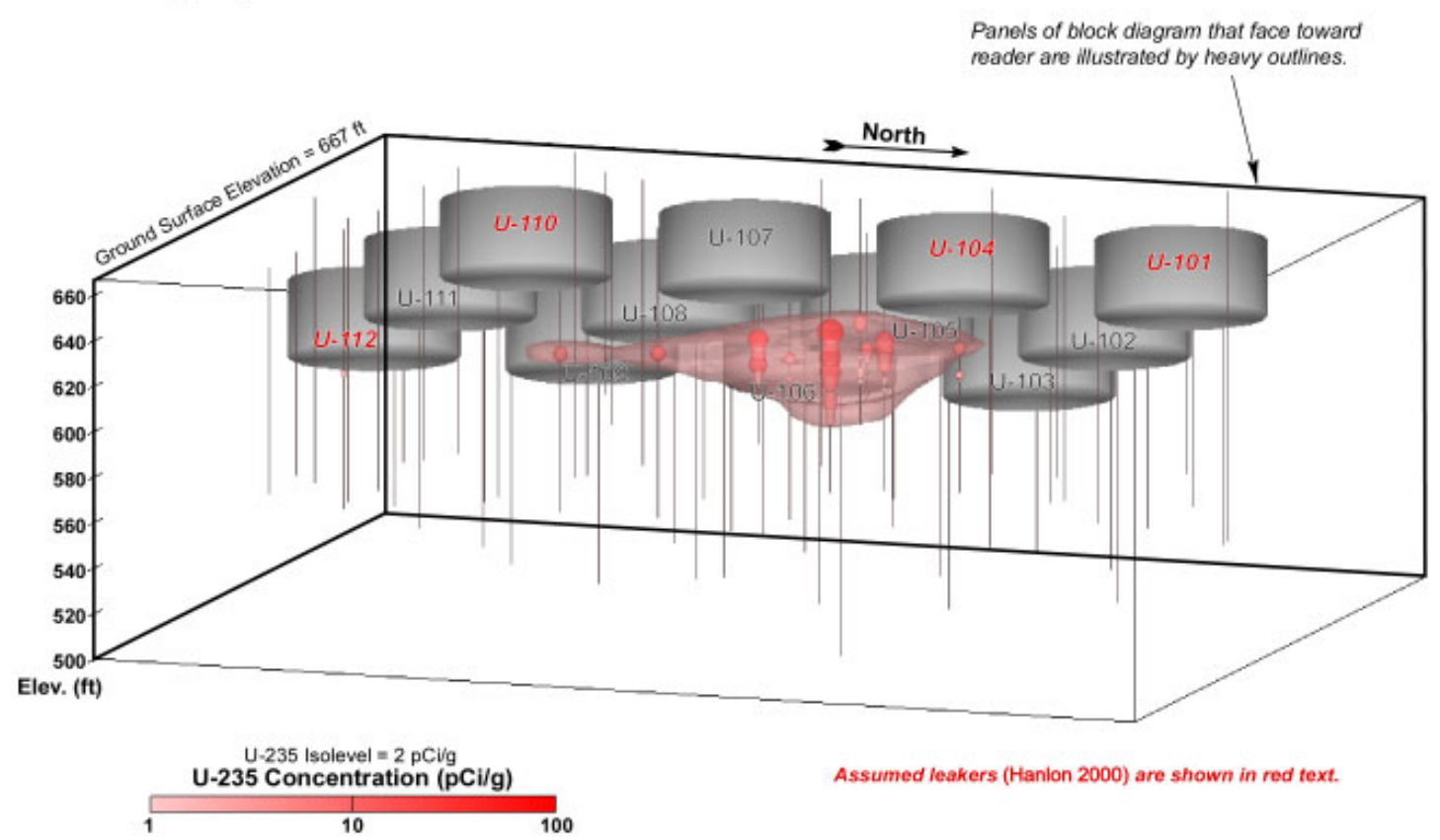

(c)

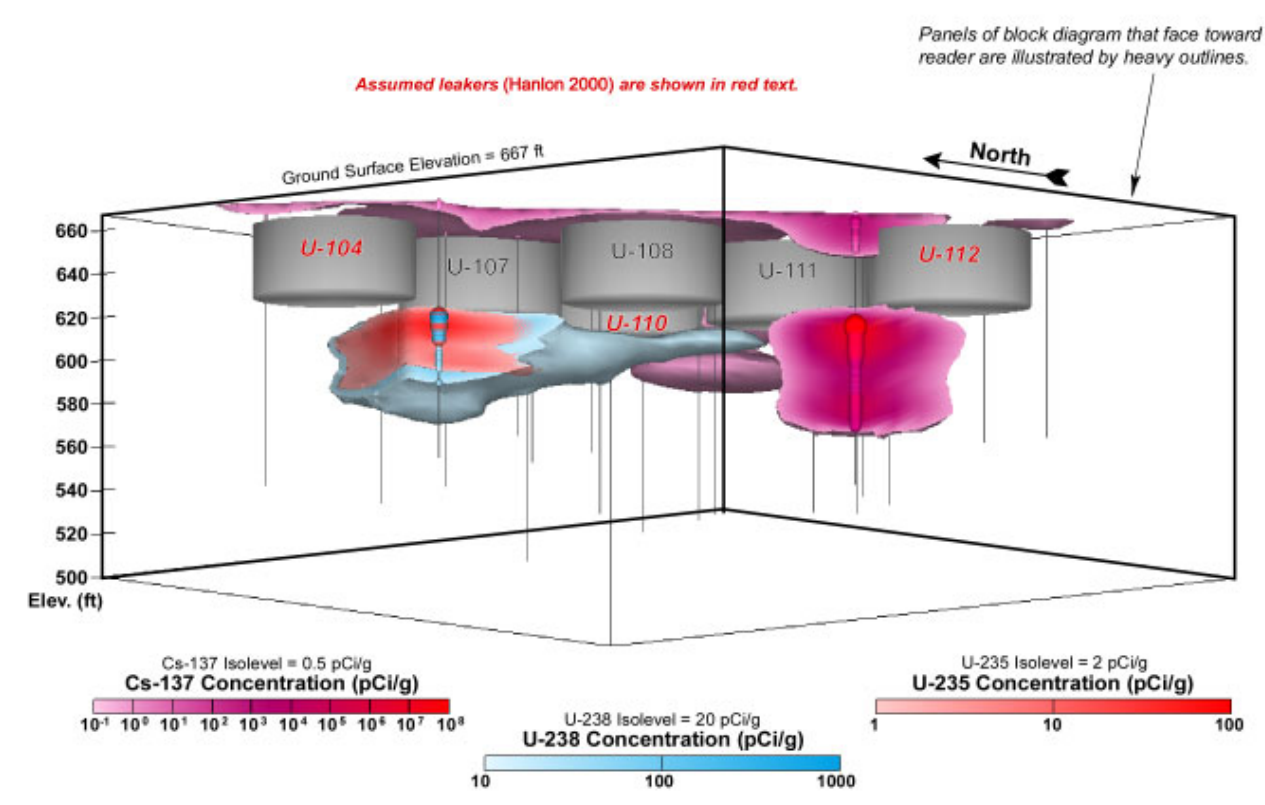

(d)

Figure 2.9. Three-Dimensional Distribution of Gamma Radionuclides Beneath Waste Management Area U (from DOE 2000) (continued) 
at the contact between two sediment units within the Hanford formation. The deepest extent of contamination detected is cesium-137 at slightly deeper than $30 \mathrm{~m}$ adjacent to tank U-112. Subsurface gamma emitting contaminants were found at various depths in the southern half of the WMA; therefore, mobile contaminants in the leaked waste would be expected to reach groundwater beneath the middle to southern half of the WMA. A surprising observation was that no subsurface contamination was found in the four drywells around tank U-101 that reportedly leaked 114,000 L of tank waste into the surrounding sediments. This could be because there are no monitoring drywells on the northern half of the tank and only one drywell on the east side of the tank.

\subsection{Groundwater Quality}

\subsection{Existing Data}

Hodges and Chou (2000) discussed groundwater quality data for WMA U. Concentrations of calcium, magnesium, sulfate, chloride, nitrate, technetium, and chromium were higher in downgradient wells than upgradient wells. None of the constituents that affected groundwater quality exceeded drinking water standards. Increases in calcium, magnesium, sulfate, chloride, and nitrate are responsible for elevated levels of specific conductance. The impacts were observed mainly in the downgradient wells on the southern half of the WMA. The pH in well 299-W19-12 is statistically higher than all other wells in the monitoring network. The cause of the elevated $\mathrm{pH}$ may be due to well construction techniques in which cement was used to seal the annulus of the well. The elevated $\mathrm{pH}$ is not currently thought to be an effect of the WMA.

\subsection{Conceptual Model}

The sources of contaminants in groundwater beneath the WMA are vadose zone plumes generated from tank leaks, pipe leaks, and various releases as described in Section 2.2. None of the releases were likely to be of sufficient volume to reach the water table independent of additional water sources. It is likely that infiltrating precipitation was focused to the sides of the tanks by the "umbrella effect" where the tops of the tanks shed percolating water to the sediments surrounding the tanks. In addition, the tank farm has received "run-on" water from snow melt and high intensity, short duration precipitation events, and pipeline leaks of clean water used in the tank farm. In addition to these sources of water, the gravel cover and the practice of removing and preventing the growth of vegetation on the surface of the WMA, encourage the infiltration of any water that reaches the area. These sources of water likely mobilized contaminants in the vadose zone where they were eventually leached to the water table where they affected groundwater quality.

Groundwater chemistry downgradient of the WMA indicates the source of contamination is close and of small volume so far. The major changes in groundwater chemistry are increases in calcium, magnesium, sulfate, and nitrate. While nitrate and sulfate are major constituents in the waste, the other ionic 
species are major components of the natural vadose zone sediments. As water moves through the vadose zone, it may encounter a contaminant plume, mix with waste solutions, incorporating sodium, nitrate, sulfate, and other soluble species from the plume and continue migrating through the vadose zone. The migrating solution encounters natural deposits of calcium carbonate and gypsum (calcium sulfate) and dissolves them in accordance with their solubility. As the solution migrates through the sediment column, soluble cations calcium, magnesium, and sodium compete for ion exchange sites on the sediment particles. Because of the limited supply of sodium, it exchanges for cations on exchange sites, leaving the solution enriched in calcium and magnesium, rather than sodium. Therefore, with a small volume or percolating liquid, the first arrival of the waste will contain elevated calcium and magnesium. Sulfate will be present because gypsum would be dissolved by the percolating solution and sulfate will be leached from any waste plumes encountered. Soluble nitrate in the waste plume would dissolve into the percolating solution and be carried downward. Technetium-99 behaves similarly to nitrate, so the percolating solution that encountered a technetium-99 bearing waste plume would also contain elevated technetium concentrations. If the percolating solution were a large volume plume of tank waste, the solution arriving at the water table would be characterized by high concentrations of sodium, nitrate, sulfate, and technetium. These conditions were not found in groundwater downgradient from the WMA. The chemical composition and low concentrations of waste constituents in groundwater downgradient of WMA U indicate that the impact has more likely been from small volumes of water leaching through existing vadose contaminant plumes.

\subsection{Data Needs}

Waste sources within WMA U caused increases in nonhazardous major ion species and co-contaminants technetium-99, nitrate, and possibly chromium in groundwater downgradient of the area. These contaminant concentrations are currently low and their presumed spatial extent is small, however, knowledge about where waste releases have occurred suggests that there are some gaps in groundwater monitoring coverage. In addition, the current conceptual model for the Site indicates that most of the released contamination is in the vadose zone; so continued groundwater monitoring is warranted to determine if contaminants are transported into the groundwater system in the future. The site conceptual model could change as additional data are collected.

\subsection{Spatial Coverage}

Five wells are currently used to monitor the WMA U. These wells, shown on Figure 2.1, are insufficient to monitor the WMA for three reasons. First, the north end of the WMA is contaminated from releases from the 244-UR-Vault and there are no wells monitoring the downgradient, eastern side of the WMA at this point. Second, well 299-W19-12 is an older well with elevated $\mathrm{pH}$ indicating that cement used in its construction may be affecting the quality of groundwater samples. Third, upgradient well 299-W18-25 went dry in 2000 and has not been replaced. Most of the contamination has and is 
currently detected downgradient of the southern end of the WMA in monitoring well 299-W19-41. An upgradient well is needed for the WMA. These wells are discussed in Section 5.2.

No monitoring wells have extended more than $10 \mathrm{~m}$ below the water table. Therefore, the vertical extent of contamination from the WMA is unknown. There are no indications that drivers currently exist to cause contamination to migrate below the current depth of the monitoring wells. Wastes released from the WMA are concentrated brines which might suggest that if a dense fluid waste reached the water table, it could migrate deeper in the groundwater system before it is transported laterally from the area. Because the wastes reaching the water table to date have been of relatively low concentration, these conditions probably have not existed. A planned well completed deeper in the groundwater system near well 299-W19-41, where the highest downgradient contamination is found, will be used to evaluate the depth of contamination below the water table.

\subsection{Groundwater Flow}

As described in Section 2.4, groundwater flow in the vicinity of WMA U has been characterized well enough to know the current flow direction and velocity. Aquifer properties such as hydraulic conductivity and specific yield have been determined from aquifer tests. As additional monitoring wells are drilled, aquifer tests will be conducted to collect additional point measurements of hydraulic conductivity. These tests are necessary because as the water table falls, the wells are completed in deeper, uncharacterized portions of the aquifer.

The major data need for groundwater flow is to continue monitoring water levels so that groundwater flow directions and gradients can be updated on a periodic basis.

\subsection{Groundwater Quality}

The major groundwater quality data needs are to monitor known tank waste constituents and indicators that could reach the water table. Trends in these constituents are needed to judge the nature of the continued impact of the WMA on groundwater quality. Samples from deeper in the aquifer will provide information about the vertical extent of contamination from the WMA.

\subsection{Groundwater Assessment Plan}

Plans presented in this section are based on data needs presented in Section 4.0. The observed impacts of the WMA on groundwater quality are minor to date, but some gaps in coverage need to be filled and the area needs to be monitored to ensure that possible future impacts are characterized. Therefore, the plans include constructing additional groundwater monitoring wells and monitoring groundwater for those Site-specific constituents contained in the wastes at frequencies appropriate for the rate of groundwater flow beneath the area, quarterly at a minimum. 


\subsection{Approach}

The original assessment, the first determination (Hodges and Chou 2000), showed that WMA U had affected groundwater quality with nonhazardous major ion species and co-contaminants technetium-99, nitrate, and chromium. Since that report was published, levels for specific conductance, nitrate, and technetium-99 have continued to rise, indicating that wastes are continuing to drain through the vadose zone. Continued groundwater monitoring will be performed to follow those trends. In addition, on a periodic basis, samples will be analyzed for other tank waste constituents to see if they have reached groundwater. Five additional wells are planned to fill some gaps along the downgradient margin of the WMA, to replace a dry upgradient well, and to explore the vertical extent of the detected contamination.

\subsection{New Wells}

Five new monitoring wells are planned for WMA U. The new well locations are shown on Figure 5.1. These wells and their locations have been agreed to between DOE and the Washington State Department of Ecology. Wells 1 through 3 will be drilled in CY 2001; wells 4 and 5 have been proposed but their construction schedule has yet to be determined. Wells 1 and 3 will be drilled on the downgradient margin of the WMA and completed in the top $10.7 \mathrm{~m}$ of the aquifer. These two wells will be evenly spaced between wells 299-W19-41 and 299-W19-42. The two new wells will replace well 299-W19-12 because groundwater samples collected from the well have elevated $\mathrm{pH}$ levels, indicating that the samples may be compromised by the cement used in construction of the well. Well 2 will be drilled on the upgradient side of the WMA, about 30 m north of existing well 299-W18-25 that is dry. Well 2 will be drilled far enough north to avoid a $U$ tank farm runoff control system that will be constructed through the area in the summer of 2001. Well 4 will be drilled directly downgradient of the 244-UR Vault. Well 4 will be drilled adjacent to well 299-W19-41 and will be drilled to the Ringold Lower Mud unit. Water samples will be collected as the well is drilled. Rapid groundwater analyses will provide information about the distribution of contaminants and ultimately where the well should be completed in the deeper part of the aquifer. The purpose of this well is to define the vertical extent of contamination at the location where the largest groundwater quality impact has been detected. Well 5 will be drilled downgradient of the north end of the WMA where releases from the 244-UR Vault occurred. These new wells will be placed on the same sampling and analysis schedule as the existing wells.

As the wells are drilled, sediment samples will be collected every $5 \mathrm{ft}$ and at changes in stratigraphy. Continuous core will be collected from ground surface to the top of the Ringold Formation or refusal in well 1. Moisture samples will be collected from the splitspoon shoe. As well 4 is drilled through the unconfined aquifer, water samples will be collected at the water table; at $10 \mathrm{~m}, 20 \mathrm{~m}$, and $30 \mathrm{~m}$ below the water table; and just above the Lower Mud Unit. These samples will be analyzed for nitrate, sulfate, and technetium-99, the major waste constituents whose elevated concentrations would indicate a WMA impact on groundwater quality. The wells will be logged by spectral gamma techniques to provide gross gamma logs and specific logs for potassium-40, uranium, thorium-234, and anthropogenic gamma emitting radionuclides before a smaller string of casing is used in the well. These data will be used 


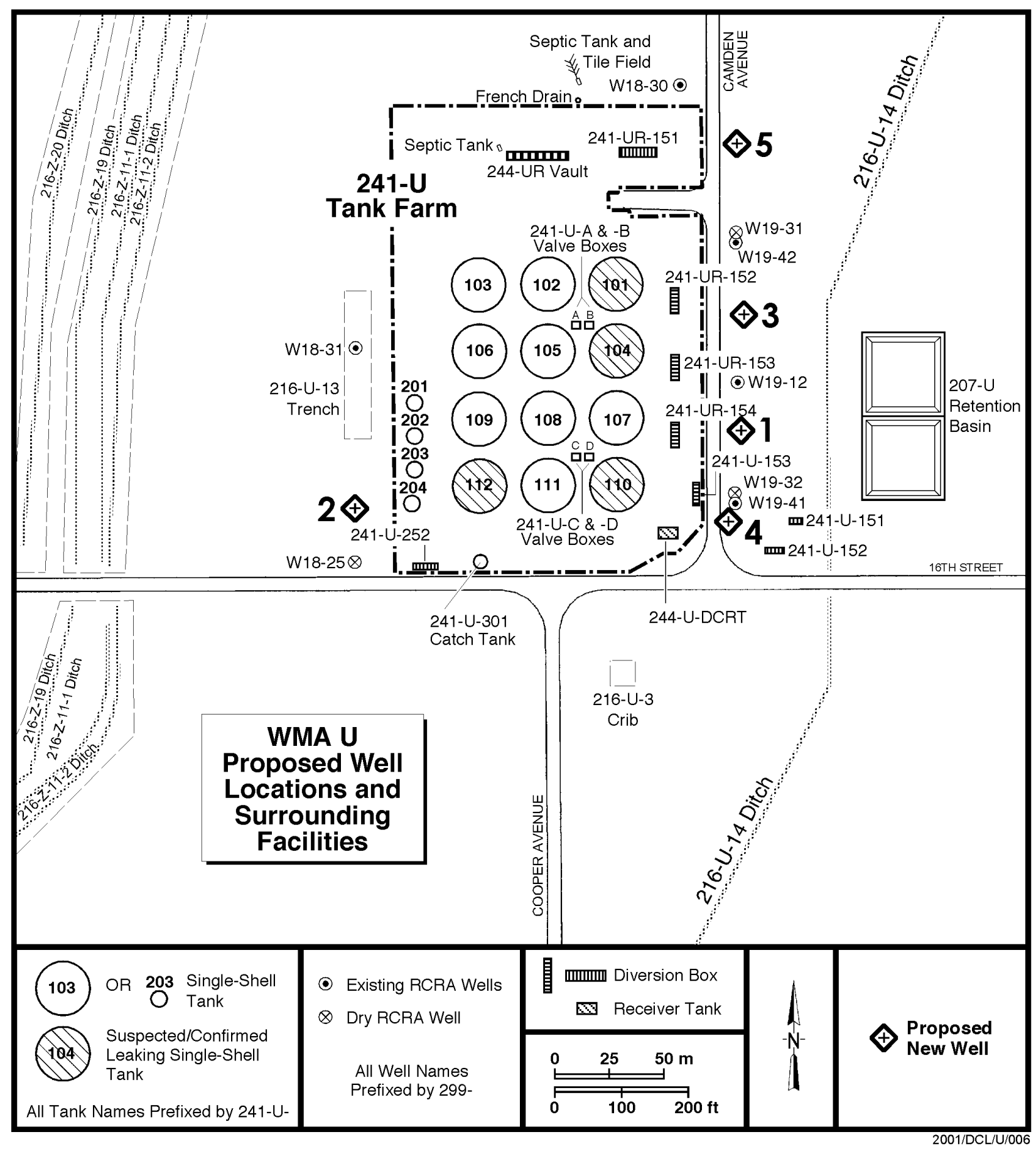

Figure 5.1. Proposed New Wells for Waste Management Area U 
to refine the geologic model of the area. The geologist's logs, geophysical logs, construction specifications, and any other information collected during drilling will be documented in borehole completion reports.

\subsection{Sampling and Analysis}

The current groundwater monitoring network consists of five wells. The wells and some of their important characteristics are presented in Table 5.1. Well 299-W18-31 is upgradient of the WMA and the other four wells are downgradient. Wells 299-W18-25, 299-W19-31, and 299-W19-32 are included for reference only because they have gone dry and can no longer be sampled. They are included because water quality data from those wells are important in understanding past groundwater conditions.

Table 5.1. Wells in Monitoring Network

\begin{tabular}{|c|c|c|c|c|c|c|}
\hline Well & $\begin{array}{l}\text { Depth to } \\
\text { Bottom } \\
\text { of } \\
\text { Screen } \\
\text { (m) }\end{array}$ & $\begin{array}{c}\text { Depth to } \\
\text { Water on } \\
3 / 1 / 01 \\
\text { (m) }\end{array}$ & $\begin{array}{l}\text { Length of } \\
\text { Water } \\
\text { Column in } \\
\text { Screen on } \\
3 / 1 / 01(\mathrm{~m})\end{array}$ & $\begin{array}{c}\text { Screen } \\
\text { Length (m) }\end{array}$ & $\begin{array}{l}\text { Construction } \\
\text { Casing/Screen }\end{array}$ & $\begin{array}{l}\text { Monitoring } \\
\text { Interval }\end{array}$ \\
\hline $299-W 18-30^{91}$ & 71.4 & 68.7 & 2.7 & 10.7 & $\mathrm{SS} / \mathrm{SS}^{\text {(a) }}$ & Top of unconfined \\
\hline $299-W 18-31^{91}$ & 67.8 & 65.7 & 2.1 & 10.7 & $\mathrm{SS} / \mathrm{SS}$ & Top of unconfined \\
\hline $299-W 19-12^{83(b)}$ & 73.2 & 68.6 & 4.6 & 12.2 & $\mathrm{CS}^{(\mathrm{c})} / \mathrm{SS}$ & Top of unconfined \\
\hline $299-W 19-41^{98}$ & 77.8 & 69.1 & 8.7 & 10.7 & $\mathrm{SS} / \mathrm{SS}$ & Top of unconfined \\
\hline $299-W 19-42^{98}$ & 77.8 & 68.9 & 8.9 & 10.7 & $\mathrm{SS} / \mathrm{SS}$ & Top of unconfined \\
\hline $299-W 18-25^{90(d)}$ & 65.5 & $65.9^{(\mathrm{e})}$ & -0.4 & 4.6 & $\mathrm{SS} / \mathrm{SS}$ & Dry \\
\hline $299-W 19-31^{90(d)}$ & 67.8 & $68.1^{(\mathrm{e})}$ & -0.3 & 4.6 & $\mathrm{SS} / \mathrm{SS}$ & Dry \\
\hline $299-W 19-32^{91(d)}$ & 67.8 & $68.3^{(\mathrm{e})}$ & -0.5 & 4.6 & $\mathrm{SS} / \mathrm{SS}$ & Dry \\
\hline \multicolumn{7}{|c|}{$\begin{array}{l}\text { Note: Superscript following well number denotes year of installation. } \\
\text { (a) Stainless steel. } \\
\text { (b) Pre-RCRA; the bottom } 3 \mathrm{~m} \text { of the well have been filled. } \\
\text { (c) Carbon steel. } \\
\text { (d) Unsampleable. } \\
\text { (e) The water table has dropped below the screen; depth to water has been approximated from nearby wells. }\end{array}$} \\
\hline
\end{tabular}

Table 5.2 presents the sampling frequency for each well and the analyses that will be performed. Additional constituents present in tank wastes may be added to the list presented in Table 5.2 and the monitoring frequency may be modified at the discretion of the project scientist based on data needs. After the new wells are sampled the first time, their sampling and analysis schedule will be adjusted so that they are sampled at the same time as the currently existing wells. 
Table 5.2. Sampling Frequency and Constituent List

\begin{tabular}{|c|c|c|c|c|c|c|c|c|c|c|c|c|c|}
\hline Well & 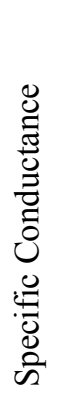 & $\frac{\pi}{2}$ & 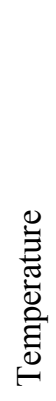 & 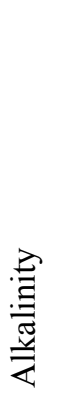 & 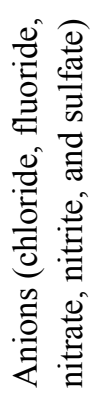 & $\frac{\sqrt[\Xi]{\frac{\pi}{\pi}}}{\sum^{\frac{\pi}{2}}}$ & 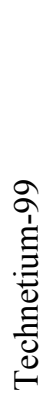 & $\begin{array}{l}\frac{\pi}{2} \\
\frac{0}{2} \\
0 \\
0 \\
0 \\
0\end{array}$ & 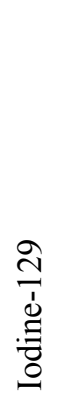 & 当 & 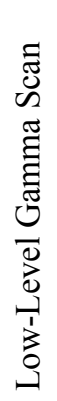 & $\begin{array}{l}\hat{e}_{n} \\
\sum_{j} \\
>\end{array}$ & 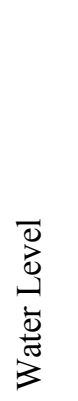 \\
\hline 299-W18-30 & Q & Q & Q & Q & Q & Q & Q & A & A & A & A & A & Q \\
\hline 299-W18-31 & $\mathrm{Q}$ & $\mathrm{Q}$ & Q & $\mathrm{Q}$ & Q & Q & Q & A & A & A & A & A & Q \\
\hline 299-W19-12 & Q & Q & Q & Q & Q & $\mathrm{Q}$ & $\mathrm{Q}$ & $\mathrm{A}$ & $\mathrm{A}$ & $\mathrm{A}$ & $\mathrm{A}$ & $\mathrm{A}$ & Q \\
\hline 299-W19-41 & $\mathrm{Q}$ & $\mathrm{Q}$ & $\mathrm{Q}$ & $\mathrm{Q}$ & Q & $\mathrm{Q}$ & Q & A & A & A & A & A & $\mathrm{Q}$ \\
\hline 299-W19-42 & Q & Q & Q & Q & Q & Q & Q & $\mathrm{A}$ & $\mathrm{A}$ & $\mathrm{A}$ & $\mathrm{A}$ & $\mathrm{A}$ & Q \\
\hline New Well $1^{(\mathrm{c})}$ & Q & Q & Q & Q & Q & Q & Q & $\mathrm{A}$ & $\mathrm{A}$ & A & $\bar{A}$ & $\mathrm{~A}$ & Q \\
\hline New Well $2^{(\mathrm{c})}$ & Q & Q & Q & Q & Q & Q & Q & A & $\mathrm{A}$ & A & A & A & Q \\
\hline New Well $3^{(\mathrm{c})}$ & Q & Q & Q & Q & $\mathrm{Q}$ & Q & Q & A & $\mathrm{A}$ & A & A & $\mathrm{A}$ & Q \\
\hline New Well $4^{(\mathrm{c})}$ & Q & Q & Q & Q & Q & Q & Q & $\mathrm{A}$ & $\mathrm{A}$ & $\mathrm{A}$ & $\mathrm{A}$ & $\mathrm{A}$ & Q \\
\hline New Well $5^{(\mathrm{c})}$ & Q & Q & Q & Q & Q & Q & Q & A & A & A & A & A & $\mathrm{Q}$ \\
\hline \multicolumn{14}{|c|}{$\begin{array}{l}\text { Note: Sampling and analysis frequency is } \mathrm{Q} \text { for quarterly (February, May, August, and } \\
\text { November) and A for annual (February). } \\
\text { (a) Metals include } \mathrm{Al}, \mathrm{Sb}, \mathrm{Ba}, \mathrm{Be}, \mathrm{Cd}, \mathrm{Ca}, \mathrm{Cr}, \mathrm{Co}, \mathrm{Cu}, \mathrm{Fe}, \mathrm{Mg}, \mathrm{Mn}, \mathrm{Ni}, \mathrm{K}, \mathrm{Ag}, \mathrm{Na}, \mathrm{Sr}, \mathrm{V}, \mathrm{Zn} \text {. } \\
\text { (b) Volatile organic compound's of specific interest are carbon tetrachloride and chloroform. } \\
\text { (c) All listed analyses will be performed on first time samples from new wells. }\end{array}$} \\
\hline
\end{tabular}

\subsection{Groundwater Flow}

Groundwater flow direction and rate must be determined regularly. These properties are determined several ways, but the standard method for this WMA has been to measure water levels in surrounding monitoring wells. Water levels will continue to be measured on a quarterly basis in all WMA U monitoring wells. These data will be converted to elevations and evaluated using trend surface analysis and shown as a water table map. Groundwater flow velocity, v, will be estimated using the Darcy equation.

Slug tests will be conducted at all new wells to determine hydraulic conductivity. Additional aquifer testing such as vertical flow tracer tests may be conducted in the future if detected contamination increases rapidly or to levels well above the drinking water standard. 


\subsection{Data Evaluation}

Water level data will be used to calculate a least squares linear surface (plane) from which groundwater flow direction and gradient are determined. Calculated water level gradients between upgradient and downgradient wells will be used to calculate the groundwater flow rate. These data will be presented as water table maps.

Groundwater chemistry data will be collected in accordance with the schedule presented in Table 5.2. These data will be evaluated using time series plots to identify any changes in trends and differences between upgradient and downgradient locations. Trends will be evaluated in light of groundwater flow; surface events such as leaks, spills, and releases of water or wastes on the WMA; and any other actions that could affect groundwater quality. The assessment strategy is to continue monitoring the WMA to determine how the existing impact on groundwater quality changes over time. Currently, groundwater contamination is at low concentrations and contaminant distribution maps are not warranted. Plume maps will be developed to depict the areal distribution of any additionally identified groundwater contamination. Constituent ratios may be used as done in Hodges and Chou (2000) to help evaluate sources of detected contamination.

\subsection{Quality Assurance}

Groundwater samples will be collected and analyzed in accordance with written contractor procedures, and data will be managed in accordance with written Pacific Northwest National Laboratory procedures, all controlled by a quality assurance project plan (QAPjP). Tasks performed in this plan will be conducted in accordance with QA plan ETD-012, Rev.2 (or latest revision). Specific items in this assessment plan controlled by the QA plan and their controlling procedures are

- Groundwater Sampling controlled by Duratek subcontract for groundwater sample collection and shipping to the lab and field measurements

- Water Level Monitoring will be controlled by Duratek subcontract and PNL-MA-567

- Analytical Analyses will be controlled by Severn Trent Laboratories, Inc., subcontract

- Data Management will be controlled by PNL-MA-567.

Quality assurance and quality control are discussed in detail for the entire PNNL Groundwater Monitoring Project in Appendix B of the annual groundwater monitoring report (Hartman et al. 2001). Specific analytical procedures are presented in Hartman (2000). 


\subsection{References}

40 CFR 265. "Interim Status Standards for Owners and Operators of Hazardous Waste Treatment, Storage, and Disposal Facilities." Code of Federal Regulations.

Anderson, J. D. 1990. A History of the 200 Area Tank Farms. WHC-MR-0132, Westinghouse Hanford Company, Richland, Washington.

Bergeron, M. P., and S. K. Wurstner. 2000. Groundwater Flow and Transport Calculations Supporting the Immobilized Low-Activity Waste Disposal Facility Performance Assessment. PNNL-13400, Pacific Northwest National Laboratory, Richland, Washington.

DOE - see U.S. Department of Energy

Hanlon, B. M. 1996. Waste Tank Summary Report for Month Ending September 30, 1996. WHC-EP0182-102, Westinghouse Hanford Company, Richland, Washington.

Hartman, M. J., ed. 2000. Hanford Site Groundwater Monitoring: Setting, Sources, and Methods. PNNL-13080, Pacific Northwest National Laboratory, Richland, Washington.

Hartman, M. J., L. F. Morasch, and W. D. Webber, eds. 2001. Hanford Site Groundwater Monitoring for Fiscal Year 2000. PNNL-13404, Pacific Northwest National Laboratory, Richland, Washington.

Hodges, F. N., and C. J. Chou. 2000. Groundwater Quality Assessment for Waste Management Area U: First Determination. PNNL-13282, Pacific Northwest National Laboratory, Richland, Washington.

Kipp, K. L., and R. D. Mudd. 1974. Selected Water Table Contour Maps and Well Hydrographs for the Hanford Reservation, 1944-1973. BNWL-B-360, Pacific Northwest Laboratory, Richland, Washington.

Lindsey, K. A., B. N. Bjornstad, J. W. Lindberg, and K. M. Hoffman. 1992. Geologic Setting of the 200-East Area: An Update. WHC-SD-EN-TI-012, Rev. 0, Westinghouse Hanford Company, Richland, Washington.

Price, W. H., and K. R. Fecht. 1976. Geology of the 241-U Tank Farm. ARH-LD-138, Atlantic Richfield Hanford, Richland, Washington.

Reidel, S. P., and K. R. Fecht. 1981. Wanapum and Saddle Mountains Basalt in the Cold Creek Syncline Area, In Subsurface Geology of the Cold Creek Syncline. RHO-BWI-ST-14, Rockwell Hanford Operations, Richland, Washington.

Resource Conservation and Recovery Act of 1976, as amended, Public Law 94-580, 90 Stat. 2795, 42 USC 6901 et seq. 
Spane, F. A., Jr., P. D. Thorne, and D. R. Newcomer. 2001. Results of Detailed Hydrologic Characterization Tests - Fiscal Year 1999. PNNL-13378, Pacific Northwest National Laboratory, Richland, Washington.

U.S. Department of Energy. 1992. U-Plant Source Aggregate Area Management Area Study Report. DOE/RL-91-52, Richland Operations Office, Richland, Washington.

U.S. Department of Energy. 1997. Vadose Zone Characterization Project at the Hanford Tank Farms U Tank Farm Report. GJO-97-1-TAR, GJO-HAN-8, Albuquerque Operations Office and Grand Junction Office, Grand Junction, Colorado.

U.S. Department of Energy. 2000. Addendum to the U Tank Farm Report. GJO-97-1-TARA, GJOHAN-8, Albuquerque Operations Office and Grand Junction Office, Grand Junction, Colorado.

Washington Administrative Code, 173-303-400. Interim Status Facility Standards. Olympia, Washington.

Washington Administrative Code, 173-303-610. Closure and Postclosure. Olympia, Washington.

Washington State Department of Ecology, U.S. Environmental Protection Agency, and U.S. Department of Energy. 1998. Hanford Federal Facility Agreement and Consent Order. Document No. 89-10, Rev. 5 (The Tri-Party Agreement) Olympia, Washington. 


\title{
Appendix A
}

Preliminary Assessment of the Hydrologic Impact of the Shutdown of ZP-1 Extraction Well 299-W15-37 within Waste Management Area U

\author{
F. A. Spane \\ March 14, 2001
}




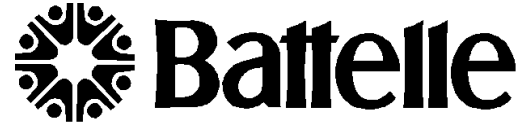 \\ ... Putting Technology To Work}

Internal Distribution
Project No. F18916

C. J. Chou

F.N. Hodges

V.G. Johnson

S.P. Luttrell

D.R. Newcomer

File/LB

Subject Preliminary Assessment of the Hydrologic Impact of the Shutdown of ZP-1 Extraction Well 299-W15-37 Within the WMA U

This letter report presents the results of a preliminary assessment of the hydrologic impact of the recent shutdown of pumping activities at a ZP-1 extraction well (299-W15-37) on groundwater conditions within the Waste Management Area (WMA) U, in the Hanford Site 200 West Area. The assessment included two analytical methods: trend-surface analysis of discrete well water-level elevation measurements for investigating changes in groundwater flow characteristics (i.e., groundwater flow direction and hydraulic gradient) within the WMA U, and dynamic well response analysis, which can be used to examine water-level trends after removal of extraneous stress effects (e.g., barometric fluctuations). Most of discussion on analytical methods used in this letter report are presented in Spane (1999) and Spane and Thorne (2000) and will not be repeated here. These analytical methods were applied to representative well measurements available within the WMA U. Previous groundwater-flow characterization investigations for other Hanford Site locations are reported in Spane (1999), for WMA 216-B-63; Spane (2000a), for WMA SST S-SX; and Spane (2000b), for LLWMA-1. Examples of dynamic well response analysis, where the effects of barometric fluctuations are removed to reveal background aquifer water-level trends are presented in Spane (1999) and Spane and Thorne (2000).

\section{Introduction}

Groundwater flow characterization is important as it pertains to predicting and monitoring groundwater contaminant migration within the Hanford Site. Accurate delineation of local groundwater-flow direction and hydraulic gradient conditions within study areas of small size and/or having low gradient conditions, however, can be difficult. A method that facilitates groundwater flow characterization in such areas is the use of trend-surface analysis of representative monitoring well water-level measurements (see Spane 1999).

Various factors can affect the accuracy of well water-level measurements and how they are used to determine hydraulic head and to infer groundwater-flow conditions within an aquifer. These factors include measurement error, well fluid-column density conditions, and external stress effects. Measurement error includes the cumulative effect of instrument and measuring point elevation errors, borehole deviation, and random measurement factors, such as operator error. 
R.M. Smith

March 14, 2001

Page 2

Systematic components of measurement error can be evaluated qualitatively by assessing the relative influence of individual well water-level measurements on the calculated groundwater flow characteristics. This was done using sensitivity analysis (i.e., "jack-knife" analysis), wherein each well's measurement was removed individually from the selected well data set, and then subjected to trend-surface analysis. Results from this sensitivity analysis suggest that systematic measurement errors were not significant for studying groundwater flow characteristics in the WMA U.

Well fluid-column density conditions relate to factors that affect the height of a fluid column in a well above a known elevation datum. Factors that can affect fluid-column density include fluid temperature, salinity, pressure, dissolved gas content, multiphase conditions, and gravitational acceleration effects. Generally, these factors are only significant for deep or thick aquifers having long fluid-column lengths, which was not the case for this investigation.

Natural external stresses that can influence well water-level measurements include barometric effects, tidal or river-stage fluctuations, and earth tides. Earlier papers have addressed these effects on well water-level measurements within confined and unconfined aquifer systems (e.g., Jacob 1940; Ferris 1963; Bredehoeft 1967; Weeks 1979; Hsieh et al. 1988; Erskine 1991). Only recently, however, has the importance of accounting for external stress factor effects in groundwater-flow characterization investigations of unconfined aquifer systems been recognized (see Rasmussen and Crawford 1997, and Spane 1999). However, since well water-level measurements used in the WMA U study were generally obtained within a period of 1 to $2 \mathrm{hr}$, no significant impact of external stresses was anticipated or accounted for prior to trend-surface analysis.

This letter report focuses specifically on assessing any subtle changes in groundwater flow characteristics within the WMA U between November 3, 2000 and March 1, 2001, as well as examining for observable hydrologic response associated with the shutdown of the southern most extraction well (well 299-W15-37) of the 200-ZP-1 pump and treat system (which occurred on January 17, 2001). Any impact of the shutdown of extraction well 299-W15-37 is anticipated to be small, due to the relatively low pumping rates at the extraction well $(\sim 60 \mathrm{~L} / \mathrm{min})$, and the distance to the RCRA WMA U monitoring wells (distance $=165-305 \mathrm{~m}$ ) analyzed in this preliminary study. In a previous study by Spane and Thorne (2000) predicted responses for the northeastern part of the ZP-1 pump and treat system potentially exceeding a radial distance of $500 \mathrm{~m}$ for prolonged extraction periods. These predictions, however, were based on the combined pumping rates of the three extraction wells in this area, which for the predictions used a composite pumping rate of $379 \mathrm{~L} / \mathrm{min}$. This is over six times the extraction rate recorded at well 299-W15-37 prior to shutdown on January 17, 2001. For these reasons, the anticipated hydrologic impact of terminating pumping at extraction well 299-W15-37 would be proportionately smaller. 
R.M. Smith

March 14, 2001

Page 3

\section{Data Discussion}

To evaluate any potential hydrologic impact at WMA U caused by terminating pumping at extraction well 299-W15-37, other factors affecting the groundwater-flow conditions in the area should also be known. Of note are the significant changes in the water table in the 200-West Area, due to past and present wastewater disposal activities in the area. Of particular importance to the study area were wastewater disposals to U Pond complex (located approximately $1000 \mathrm{~m}$ southwest of the WMA U, which received approximately $60 \%$ of the total wastewater released in the 200-West Area (Newcomer 1990). These wastewater disposal activities caused discernable changes in the prevailing groundwater flow pattern and formation of a large groundwater mound with elevated water-table conditions approximately $20 \mathrm{~m}$ over pre-disposal conditions (Hartman and Dresel 1998).

With the decommissioning of U Pond in 1984, a significant decrease in wastewater disposal and associated decline in water-table elevation were exhibited across the 200-West Area. For example, Hartman and Dresel (1998) report a $6 \mathrm{~m}$ decline between 1984 and 1997. The decline in the water table and changes in groundwater flow characteristics are expected to continue with future decreases in wastewater releases to 200-West Area disposal facilities.

To evaluate existing and temporal groundwater flow characteristics within the WMA U area prior to and immediately following the termination of pumping at extraction well 299-W15-37, well water-level measurements were evaluated from RCRA monitoring wells within the WMA. Figure 1 shows the locations of monitoring wells having data for groundwater-flow characterization. Table 1 lists pertinent information concerning well completion, current monitoring conditions for the RCRA wells, and distance to ZP-1 extraction well 299-W15-37.

\section{Groundwater Flow Characterization}

In previous detailed groundwater-flow characterization studies at selected Hanford Site WMA locations reported in Spane (1999) and Spane (2000a, 2000b), water-level measurements were used in the trend-surface analysis for wells that met the following criteria:

- are along the same hydrologic flow plane (i.e., planar potential surface)

- are measured close in time (e.g., 1 to $4 \mathrm{~h}$ for low-gradient areas)

- monitor similar depth intervals within the respective hydrogeologic unit

- display similar dynamic well-response characteristics (e.g., to barometric fluctuations)

- are not significantly affected by well-skin effects.

This site was identified in Hartman et al.(2000) as being an intermediate-hydraulic gradient area $(\sim 0.002)$, and having a predominant, easterly, groundwater-flow direction. The criteria for wells being on the same hydrologic flow plane would appear to be met. 
R.M. Smith

March 14, 2001

Page 4

As noted previously, well measurements used in the trend-surface analysis were obtained close in time (e.g. 1 to $2 \mathrm{~h}$ ) for all dates analyzed, and all wells monitor the upper-section of the unconfined aquifer within the WMA U. The overall similar well water-level patterns displayed in Figure 2 suggests that the wells exhibit similar dynamic well-response characteristics and that wellskin effects are not likely to impose significant impacts on water-level measurements between wells. A comparison of a detailed barometric response analysis for monitor wells 299-W18-31 and -W19-42 (described later in the letter report) also exhibited nearly identical barometric behavior, with demonstrated time-lag effects up to $50 \mathrm{~h}$ for these sites.

Because of the similar dynamic well-response characteristics, intermediate hydraulic gradient conditions (i.e., $~ 0.002$ ), and closeness of well measurements in time, no significant impact of barometric effects was anticipated for measurements used in the trend-surface analysis. Therefore, no accounting of barometric effects was utilized for well water-level measurements for this phase of the study.

\section{Trend-Surface Analysis Results}

Available RCRA WMA U monitoring well data were quantitatively evaluated for groundwaterflow characterization using the screening criteria listed previously. Figure 2 shows the similarity in dynamic well-response characteristics exhibited for the six monitoring wells over the time period selected for detailed groundwater-flow characterization. The overall declining water-level elevation trend pattern is consistent with the general decrease in total wastewater disposal within the 200-West Area during the mid-1980's as previously discussed.

To facilitate quantitative determination of groundwater-flow direction and hydraulic gradient conditions, the commercially available WATER-VEL (In-Situ, Inc. 1991) software program was utilized. Water-level elevation and calculated total head values were used with the WATER-VEL program to calculate groundwater-flow direction and hydraulic gradient conditions over the measurement period. The program utilizes a linear, two-dimensional trend surface (least squares) to randomly located hydrologic head or water-level elevation input data. This technique is accurate as long as the two-dimensional linear approximation is applicable (i.e., no significant vertical groundwater-flow gradients exist within the aquifer). This method is similar also to the linear approximation technique described by Abriola and Pinder (1982) and Kelly and Bogardi (1989). A report that demonstrates the use of the WATER-VEL program for calculation of groundwater-flow velocity and direction is presented in Gilmore et al. (1992) and Spane (1999).

To quantitatively assess the groundwater-flow characteristics within the WMA U over the November 3, 2000 to March 1, 2001 time period, observed well water-level elevation measurements (not adjusted for barometric effects) were analyzed. Table 2 lists the results of quantitative trend-surface analysis for nine selected measurement periods for the six existing RCRA monitoring wells during the period of investigation. As shown, a consistent easterly flow direction (ranging between $6^{\circ}$ and $12^{\circ}$; average $=10^{\circ}$. Note: 0 degrees $=$ East; 90 degrees $=$ North) and hydraulic gradient (ranging between 0.00199 and 0.00215 ; average $=0.00208$ ) are indicated for all nine measurements. No appreciable change in groundwater flow characteristics (i.e., flow direction or gradient) are evident within the WMA U, due to the shutdown of extraction well 299-W15-37, based on the trend-surface analysis results for all RCRA wells within this area. 
R.M. Smith

March 14, 2001

Page 5

To examine for the presence of any apparent groundwater flow pattern differences across the WMA facility, an evaluation for the northern WMA U area was also initiated. Four RCRA monitoring wells in this immediate area (wells 299-W18-30, 299-W18-31, 299-W19-12, and 299W19-42) were selected for this areal analysis. Table 3 lists the results of the trend-surface analysis for the same measurement periods. As shown, nearly identical temporal groundwater flow characteristics were exhibited for the northern $U$ area as were exhibited for the entire WMA U (Table 2). Results from the trend-surface analysis for the four northern monitor wells provide a consistent easterly flow direction (ranging between $4^{\circ}$ and $11^{\circ}$; average $=9^{\circ}$ ) and hydraulic gradient (ranging between 0.00208 and 0.00231 ; average $=0.00219$ ) for all nine measurements.

To examine for any possible groundwater flow pattern differences within the southern half of the WMA facility, four RCRA monitoring wells in this immediate area (wells 299-W18-25, 299-W18-31, 299-W19-12, and 299-W19-41) were selected. Note: wells 299-W18-31 and 299W19-12 are shared wells for the north and south WMA U analysis areas. Table 4 lists the results of the trend-surface analysis for the same measurement periods. As shown, nearly identical temporal groundwater flow characteristics were exhibited for the southern $\mathrm{U}$ area as were exhibited for the entire (Table 2) and northern WMA U (Table 3), respectively. Results from the trend-surface analysis for the four southern monitor wells provide a consistent easterly flow direction (ranging between $4^{\circ}$ and $14^{\circ}$; average $=8^{\circ}$ ) and hydraulic gradient (ranging between 0.00199 and 0.00215; average $=0.00207$ ) for all nine measurements. It should be noted that a small $\left(\sim 5^{\circ}\right)$ change in flow direction for the southern monitor wells is evident for the last four measurement periods. It is not readily apparent, however, whether this slight change in flow direction can be directly attributable to the termination of pumping activities from extraction well 299-W15-37; particularly since no similar pattern was exhibited for the northern wells, which one would expect to be more affected by well 299-W15-37 effects.

In summary, no significant impact on groundwater flow characteristics (i.e., flow direction and hydraulic gradient) within the WMA U were discernable over the relatively short, six-week period following termination of pumping activities at nearby extraction well 299-W15-37. While trendsurface analysis methods are very useful in detecting changes in flow direction or hydraulic gradient over time, they are rather insensitive for direct detection of hydrologic response or influence at individual monitor well locations. Detection of possible hydrologic effects from well 299-W15-37 within the WMA U, requires quantitative analysis (i.e., dynamic well response analysis) of closely-spaced (in time) well water-level measurements. This quantitative analysis procedure is described in the following section.

\section{Hydrologic Response}

As noted previously, the potential hydrologic impact of terminating pumping activities at extraction well 299-W15-37 is anticipated to be extremely small. For example, if the areal hydrologic properties determined by Spane and Thorne (2000) for the northeast section of the ZP-1 are representative of conditions within the WMA U, then termination of pumping at extraction well 299-W15-37 is anticipated to produce only a recovery response of $\sim 0.1 \mathrm{~m}$ after 30 days in the northern half of WMA U. This response magnitude is difficult to discern visually from 
R.M. Smith

March 14, 2001

Page 6

well water-level records, given the presence of daily barometric fluctuations and the long-term water-table trend (decline) that is occurring within this area. Methods have recently been developed, however, that facilitate removal of masking barometric pressure fluctuations; enabling recognition of potential hydrologic responses associated with pumping activities.

To assess whether the shutdown of extraction well 299-W15-37 had a hydrologic impact within the WMA U, two RCRA monitor wells (299-W18-31 and 299-W19-42) were selected for high-frequency well water-level response data collection. The monitor wells are located on the west and east side of the WMA, respectively (see Figure 1), and are between 173 and $220 \mathrm{~m}$ from extraction well 299-W15-37 (see Table 1). Well water-level data were measured every 10 min with pressure transducers suspended a short distance below the water-level surface. Data were stored in surface data loggers and retrieved on a weekly or bi-weekly basis. Well water-level measurements were also collected manually on those days that data were retrieved from the data loggers.

Figure 3 shows the baseline response of water-levels with monitor wells 299-W18-31 and 299W19-42 for a 28-d period prior to and following shutdown of extraction well 299-W15-37 on January 17, 2001 (calendar day 383). As shown, the well water-level responses are nearly identical and display a typical inverse relationship to barometric pressure fluctuations. To ascertain any background hydrologic response within the aquifer, the effects of barometric pressure on the well water-level measurements were removed using the multiple-regression deconvolution technique, which is discussed in detail in Rasmussen and Crawford (1997) and Spane (1999).

The removal process requires that the well barometric response characteristics be determined first using multiple-regression convolution techniques. Monitor well water-levels and barometric pressures were analyzed for the 28 -d period immediately prior to shutdown of well 299-W15-37. Linear trends in the pre-shutdown water-level and barometric pressure were determined using linear regression analysis and removed from the data. Use of detrended data allows for a more quantitative analysis of barometric response characteristics, and facilitates detection of background trends within the water-level record when barometric effects are removed. Figure 4 presents the barometric response function characteristics for both monitor wells, showing persistent barometric time-lag effects up to 50-hr at both sites. As indicated, the barometric response characteristics are nearly identical and are typical of an unconfined aquifer pattern with minor wellbore storage/skin effects, as discussed in Spane (1999).

Figure 5 shows the predicted (based on the observed barometric pressure record) and the barometric-corrected well water-level response for monitor well 299-W18-31. The deviation between the observed and predicted response for the 7 - $10 \mathrm{~d}$ period prior to well 299-W15-37 shutdown is indicative of the presence of a background water-level trend (decline) within the aquifer. Additionally, the later match between the observed and predicted response is indicative of a reversal in the background water-level trend during the post-shutdown period. This is more clearly shown in the barometric-corrected response, where the obscuring effects of barometric pressure fluctuation have been removed. As shown, a declining water-level trend of $-0.0027 \mathrm{~m} / \mathrm{d}$ is indicated for the $\sim 28$ - $\mathrm{d}$ pre-shutdown period, while a $+0.0015 \mathrm{~m} / \mathrm{d}$ was calculated for the $\sim 28-\mathrm{d}$ 
R.M. Smith

March 14, 2001

Page 7

post-shutdown period using linear-regression of the corrected water-level response. Interestingly, the projected recovery response $(+0.0042 \mathrm{~m} / \mathrm{d})$ after 1 month amounts to $\sim 0.1 \mathrm{~m}$, which is consistent to what was previously predicted within the northern WMA U for the extraction well shutdown.

Figure 6 shows the predicted and the barometric-corrected well water-level response for monitor well 299-W19-42. As shown, a similar overall pattern and identical pre-shutdown trend with monitor well 299-W18-31 are indicated. A higher post-shutdown trend $(+0.0029 \mathrm{~m} / \mathrm{d})$, however, was calculated for well 299-W19-42. It should be noted, that the pressure transducer system was removed temporarily from this well during the first week following the extraction well shutdown to support scheduled water-sampling activities at this site. It is not known, whether this apparent change in post-shutdown trend for this well site is real or an artifact of changes to the pressure transducer measuring system.

In summary, dynamic well response analysis reveals the presence of a reversal in aquifer waterlevel trends within the WMA U for the 28 -d period immediately prior to and following shutdown of pumping activities at ZP-1 extraction well 299-W15-37. While the magnitudes in calculated water-level trends are small, the timing of the trend reversal suggests that the termination of pumping at extraction well 299-W15-37 is the causative factor. It is likely that the impact of the shutdown is temporary, and with time the influence of the more dominant area-wide decline in aquifer water levels occurring within the 200-West Area (e.g., due to U-Pond decommissioning) will be reestablished within the WMA U. 
R.M. Smith

March 14, 2001

Page 8

\section{References}

Abriola LM and GF Pinder. 1982. "Calculation of velocity in three space dimensions from hydraulic head measurements.” Ground Water 20(2):205-213.

Bredehoeft JD. 1967. "Response of well-aquifer systems to earth tides." Journal of Geophysical Research 72(12):3075-3087.

Erskine AD. 1991. "The effect of tidal fluctuation on a coastal aquifer in the UK." Ground Water 29(4):556-562.

Gilmore TJ, DR Newcomer, SK Wurstner, and FA Spane, Jr. 1992. Calculation of groundwater discharge to the Columbia River in the 100-N area. PNL-8057, Pacific Northwest Laboratory, Richland, Washington.

Hartman MJ and PE Dresel (eds.). 1998. Hanford Site groundwater monitoring for fiscal year 1997. PNNL-11793, Pacific Northwest National Laboratory, Richland, Washington.

Hartman MJ, LF Morasch, and WD Webber, (eds). 2000. Hanford Site groundwater monitoring for fiscal year 1999. PNNL-13116, Pacific Northwest National Laboratory, Richland, Washington

Hsieh PA, JD Bredehoeft, and SA Rojstaczer. 1988. "Response of well aquifer systems to earth tides: Problem revisited. Water Resources Research 24(3):468-472.

In-Situ, Inc. 1991. WATER-VEL ${ }^{T M}$ groundwater velocity. ISI-GWV-2.21-1, Laramie, Wyoming. Jacob CE. 1940. "On the flow of water in an elastic artesian aquifer." American Geophysical Union, Transactions 14:446-460.

Kelly WE and I Bogardi. 1989. "Flow directions with a spreadsheet." Ground Water - Computer Notes 27(2):245-247.

Newcomer DR. 1990. Evaluation of Hanford Site Water-Table Changes - 1980 - 1990. PNL-7498, Pacific Northwest Laboratory, Richland, Washington.

Rasmussen TC and LA Crawford. 1997. "Identifying and removing barometric pressure effects in confined and unconfined aquifers.” Ground Water 35(3):502-511.

Spane FA, Jr. 1999. Effects of barometric fluctuations on well water-level measurements and aquifer test data. PNNL-13078, Pacific Northwest National Laboratory, Richland, Washington.

Spane, FA, Jr. 2000a. Groundwater flow characterization within the S-SX tank farm vicinity; Hanford Groundwater Monitoring Project letter report to V.G. Johnson, March 23, 2000, 17 p.

Spane FA, Jr. 2000b. Detailed groundwater-flow characterization within low-gradient areas: initial results for LLWMA-1; letter report to R.B. Mercer (Site-Wide Project), December 12, 2000. 
R.M. Smith

March 14, 2001

Page 9

Spane FA, Jr., and PD Thorne. 2000. Analysis of the bydrologic response associated with shutdown and restart of the 200-ZP-1 pump-and-treat system. PNNL-13342, Pacific Northwest National Laboratory,

Richland, Washington.

Weeks EP. 1979. "Barometric fluctuations in wells tapping deep unconfined aquifers." Water Resources Research 15(5):1167-1176. 
R.M. Smith

March 14, 2001

Page 10

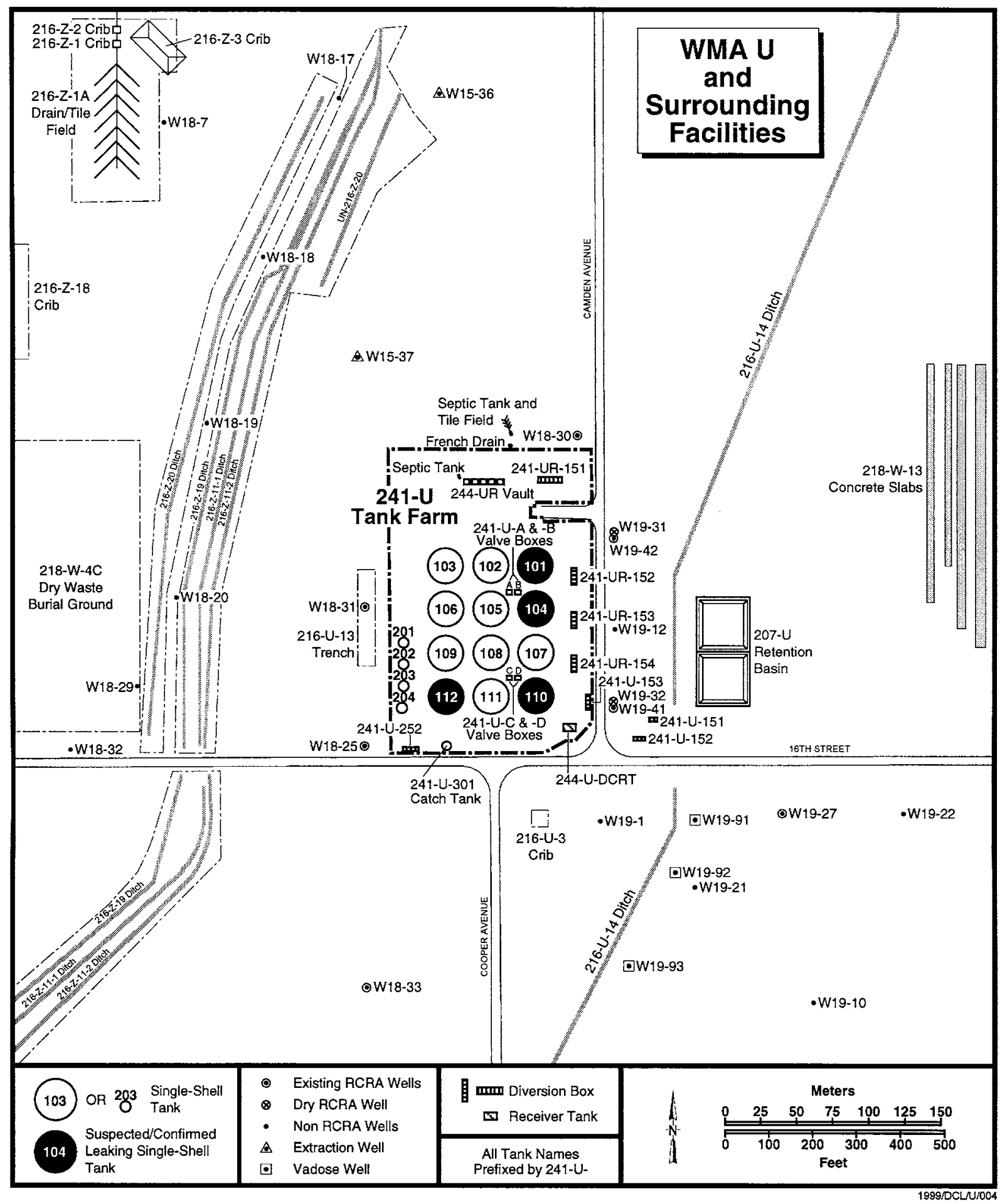

Figure 1. Location Map of Wells Monitoring the WMA U, 200-West Area. 
R.M. Smith

March 14, 2001

Page 11

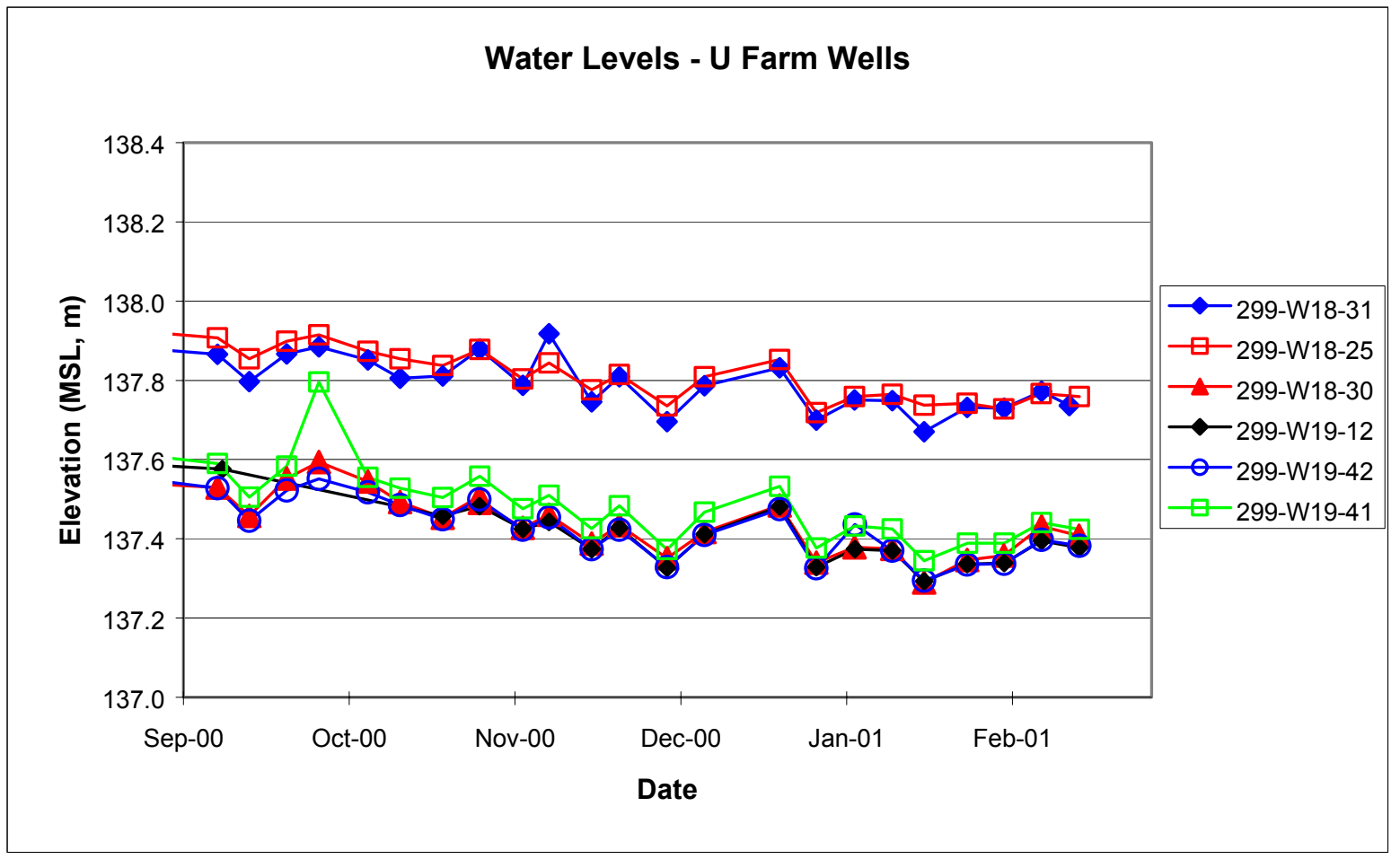

Figure 2. Comparison of Well Water-Level Elevation Response for RCRA Wells Monitoring the WMA U 
R.M. Smith

March 14, 2001

Page 12

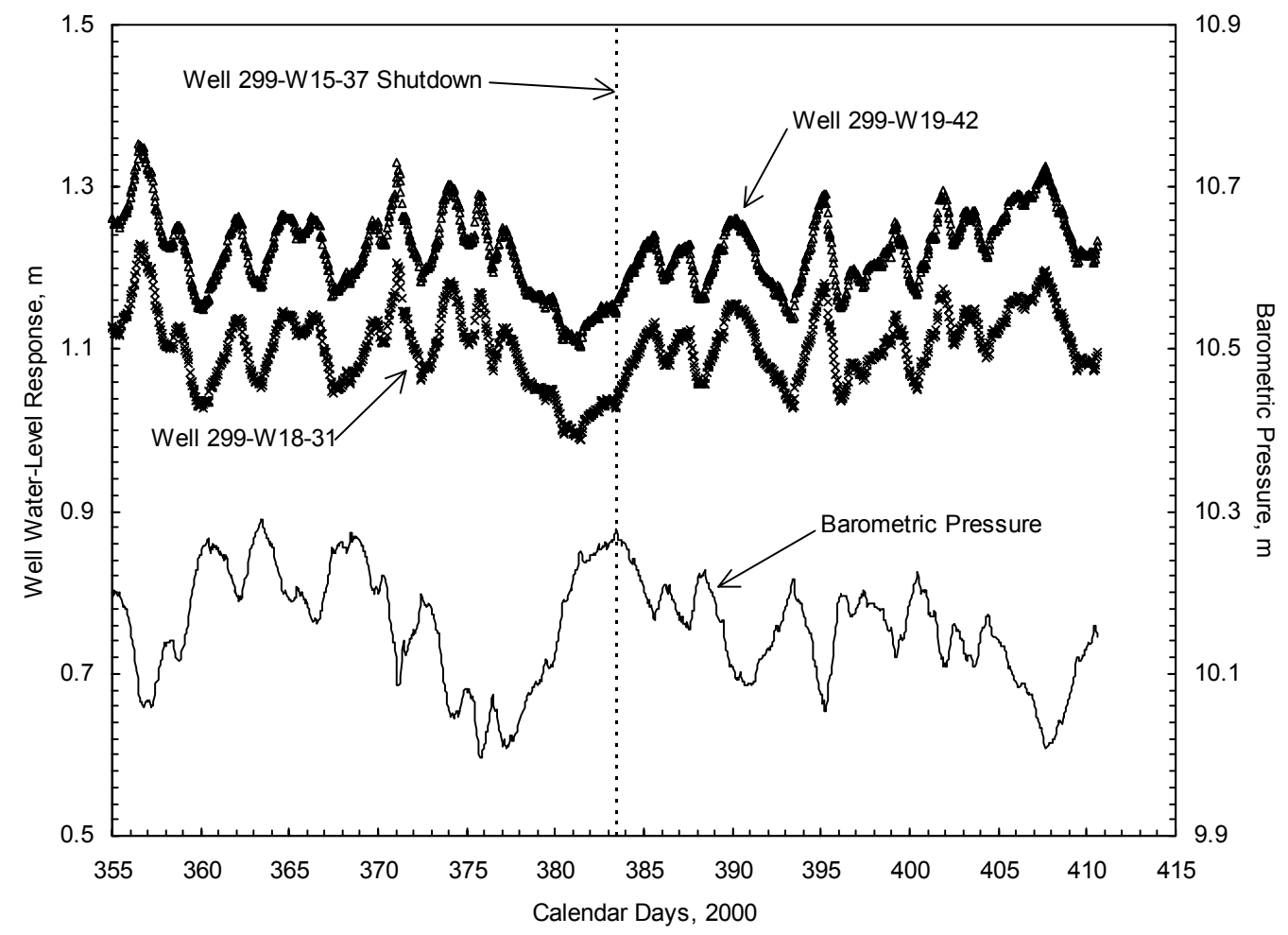

Figure 3. Baseline Monitor Well Water-Levels (Wells 299-W18-31 and-W19-42) and Barometric Pressure Response for the $\sim 28$-d Period Prior to and Following Shutdown of ZP-1 Extraction Well 299-W15-37. 
R.M. Smith

March 14, 2001

Page 13

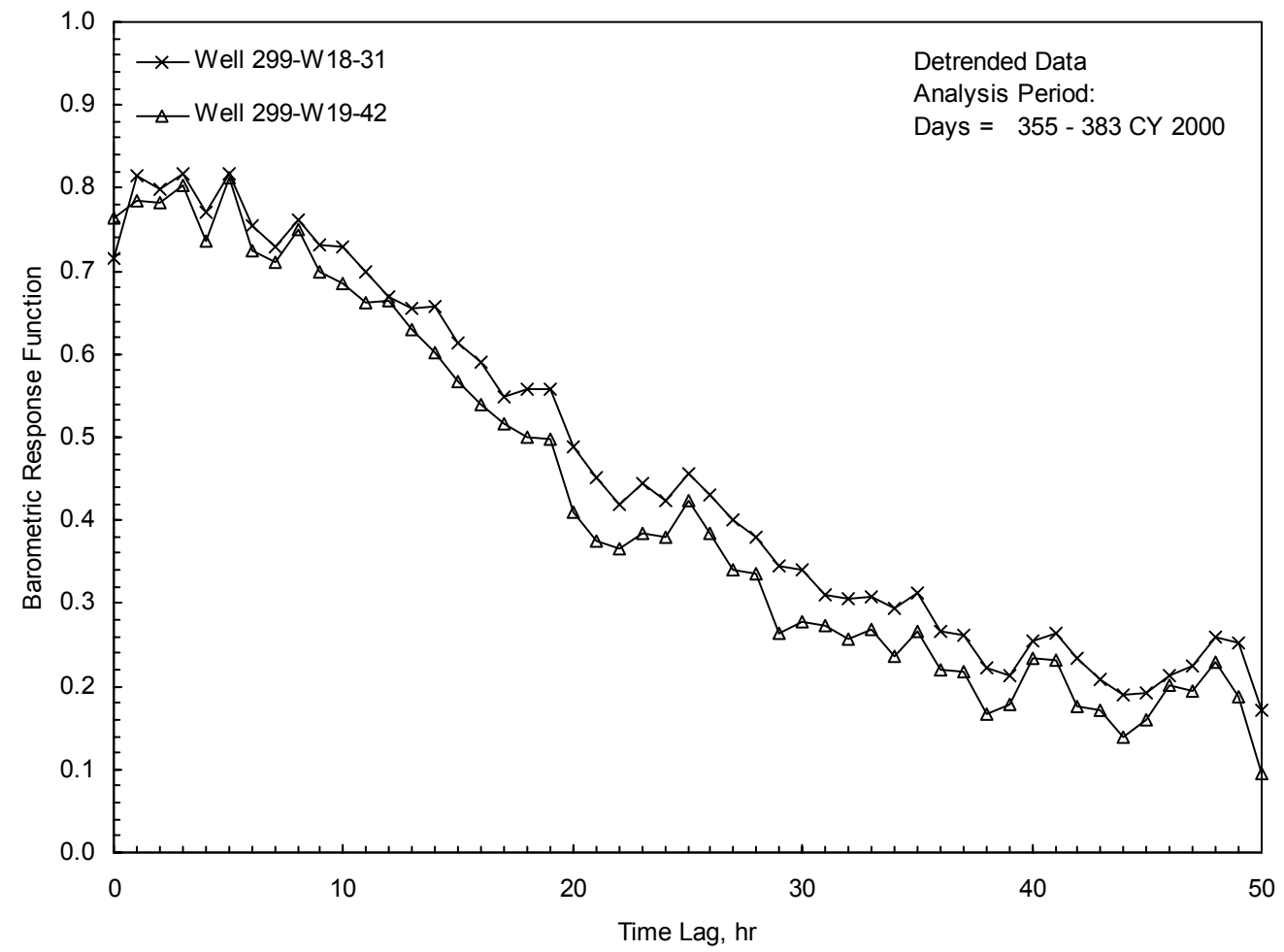

Figure 4. Barometric Response Analysis for Monitor Wells 299-W18-31 and 299-W19-42 
R.M. Smith

March 14, 2001

Page 14

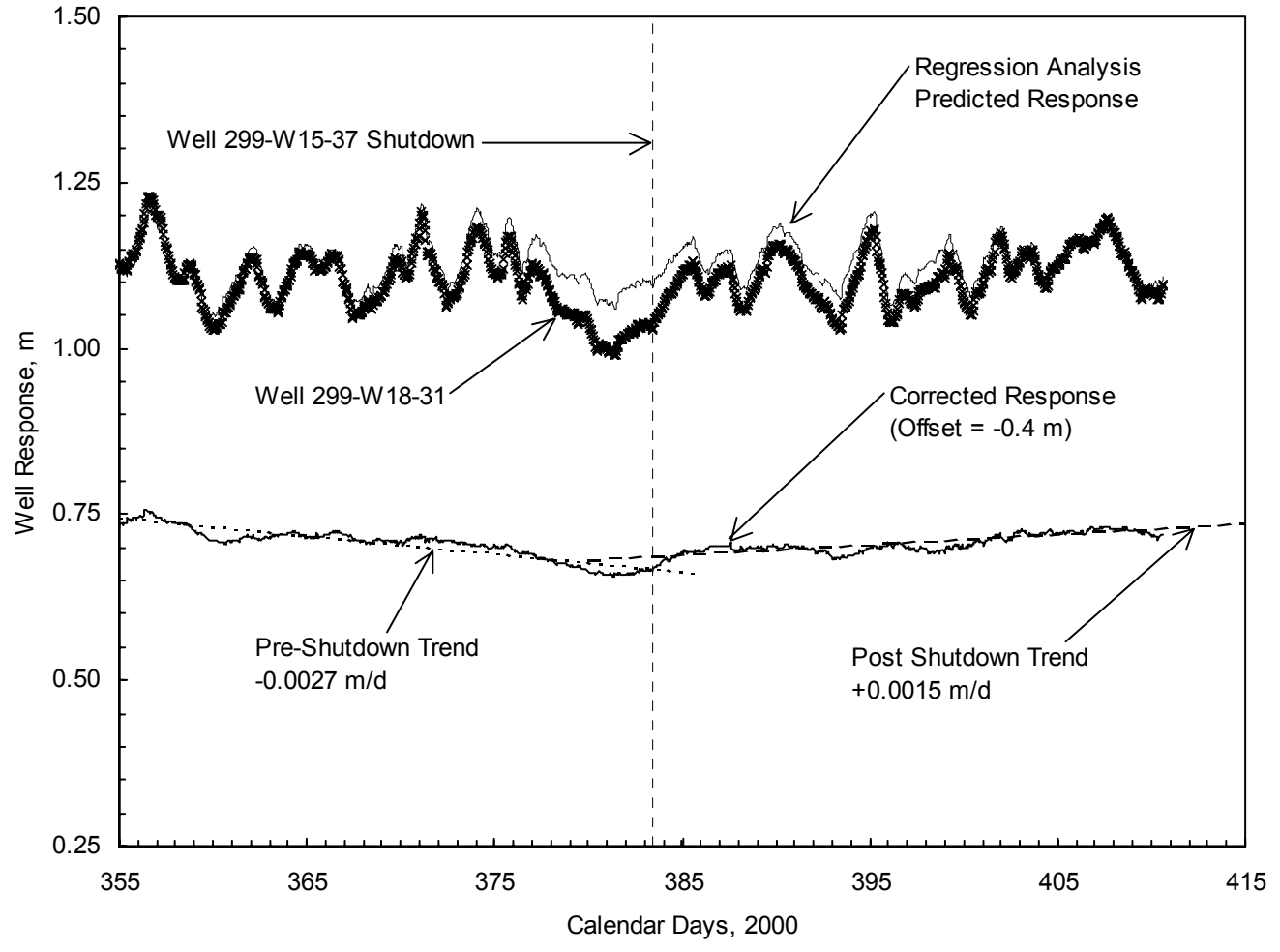

Figure 5. Multiple-Regression Match and Barometric Corrected Water Levels for Monitor Well 299-W18-31 
R.M. Smith

March 14, 2001

Page 15

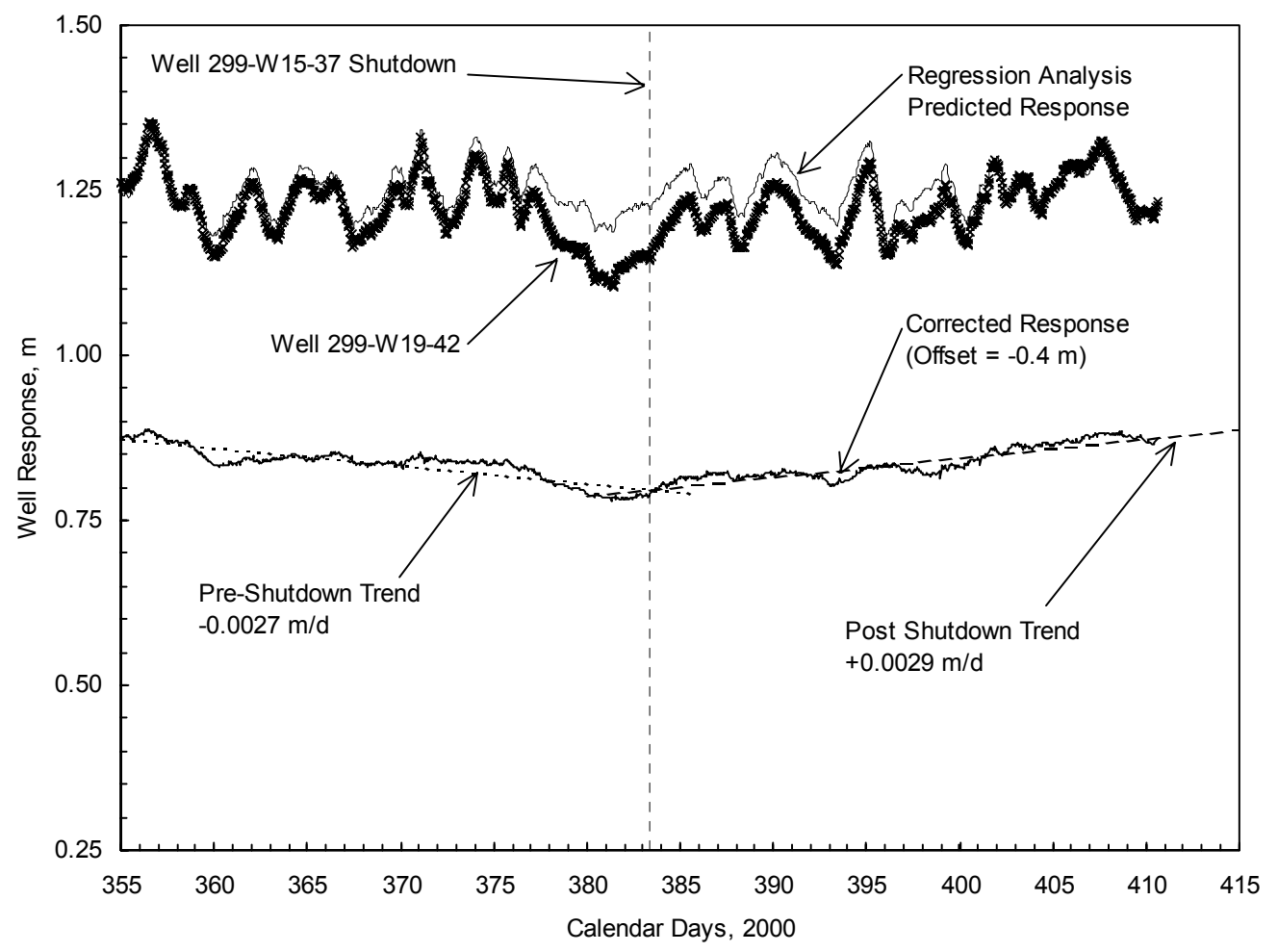

Figure 6. Multiple-Regression Match and Barometric Corrected Water Levels for Monitor Well 299-W19-42 
R.M. Smith

March 14, 2001

Page 16

Table 1. Pertinent Well Completion Information for RCRA Wells Monitoring the WMA U Facilities

\begin{tabular}{|c|c|c|c|c|c|}
\hline Well & $\begin{array}{c}\text { Completion } \\
\text { Date } \\
\mathrm{M} / \mathrm{Yr}\end{array}$ & $\begin{array}{c}\text { Well Screen } \\
\text { Length } \\
\text { m, bgs }\end{array}$ & $\begin{array}{l}\text { Water- } \\
\text { Level } \\
\text { Depth, } \\
\text { m, bgs }\end{array}$ & $\begin{array}{l}\text { Water-Column } \\
\text { Length } \\
\text { Above Well Screen } \\
\text { Bottom, } \\
\text { m }\end{array}$ & $\begin{array}{l}\text { Distance to ZP-1 } \\
\text { Extraction Well } \\
\text { 299-W15-37, } \\
\text { m }\end{array}$ \\
\hline 299-W18-25 & $12 / 90$ & $\begin{array}{c}58.98- \\
65.47\end{array}$ & $\begin{array}{l}65.24 \\
(9 / 00)\end{array}$ & $\begin{array}{c}0.23 \\
(9 / 00)\end{array}$ & 270.1 \\
\hline 299-W18-30 & $11 / 91$ & $\begin{array}{c}60.20- \\
71.41\end{array}$ & $\begin{array}{l}67.48 \\
(9 / 00)\end{array}$ & $\begin{array}{c}3.93 \\
(9 / 00)\end{array}$ & 163.7 \\
\hline 299-W18-31 & $12 / 91$ & $\begin{array}{c}57.09- \\
67.76\end{array}$ & $\begin{array}{l}64.15 \\
(9 / 00)\end{array}$ & $\begin{array}{c}3.61 \\
(9 / 00)\end{array}$ & 173.2 \\
\hline |299-W19-12 & $1 / 83$ & $\begin{array}{c}64.01- \\
76.20\end{array}$ & $\begin{array}{c}68.11 \\
(9 / 00)\end{array}$ & $\begin{array}{c}8.09 \\
(9 / 00)\end{array}$ & 261.4 \\
\hline 299-W19-41 & $9 / 98$ & $\begin{array}{c}67.07- \\
77.77\end{array}$ & $\begin{array}{l}67.99 \\
(9 / 00)\end{array}$ & $\begin{array}{c}9.78 \\
(9 / 00)\end{array}$ & 303.1 \\
\hline 299-W19-42 & $9 / 98$ & $\begin{array}{c}67.14- \\
77.84\end{array}$ & $\begin{array}{l}67.96 \\
(9 / 00)\end{array}$ & $\begin{array}{c}9.88 \\
(9 / 00)\end{array}$ & 219.7 \\
\hline
\end{tabular}


R.M. Smith

March 14, 2001

Page 17

Table 2. Groundwater-Flow Characterization Results Based on Trend-Surface Analysis: All RCRA U WMA Monitor Wells

\begin{tabular}{|c|c|c|}
\hline Measurement Date & $\begin{array}{l}\text { Groundwater-Flow } \\
\text { Direction }^{(a)}\end{array}$ & $\begin{array}{l}\text { Hydraulic Gradient, } \\
\qquad \mathrm{m} / \mathrm{m}\end{array}$ \\
\hline $11 / 3 / 00$ & $12.0^{\circ}$ & 0.00199 \\
\hline $11 / 30 / 00$ & $9.9^{\circ}$ & 0.00208 \\
\hline $12 / 28 / 00$ & $10.7^{\circ}$ & 0.00205 \\
\hline $1 / 11 / 01$ & $11.9^{\circ}$ & 0.00207 \\
\hline $1 / 25 / 01$ & $10.7^{\circ}$ & 0.00215 \\
\hline $2 / 1 / 01$ & $8.9^{\circ}$ & 0.00210 \\
\hline 2/8/01 & $6.3^{\circ}$ & 0.00202 \\
\hline $2 / 22 / 01$ & $9.9^{\circ}$ & 0.00209 \\
\hline $3 / 1 / 01$ & $11.4^{\circ}$ & 0.00213 \\
\hline Average & $\begin{array}{l}10.2^{\circ} \\
\left( \pm 1.8^{\circ}\right)\end{array}$ & $\begin{array}{c}0.00208 \\
( \pm 0.00006)\end{array}$ \\
\hline \multicolumn{3}{|c|}{$\begin{array}{l}\text { RCRA monitor wells used in analysis: 299-W18-25, -W18-30, - } \\
\text { W18-31, }\end{array}$} \\
\hline
\end{tabular}


R.M. Smith

March 14, 2001

Page 18

Table 3. Groundwater-Flow Characterization Results Based on Trend-Surface Analysis: North RCRA U WMA Monitor Wells

\begin{tabular}{|c|c|c|}
\hline Measurement Date & $\begin{array}{c}\text { Groundwater-Flow } \\
\text { Direction }^{(a)}\end{array}$ & $\begin{array}{l}\text { Hydraulic Gradient, } \\
\mathrm{m} / \mathrm{m}\end{array}$ \\
\hline $11 / 3 / 00$ & $10.8^{\circ}$ & 0.00208 \\
\hline $11 / 30 / 00$ & $6.6^{\circ}$ & 0.00210 \\
\hline $12 / 28 / 00$ & $9.2^{\circ}$ & 0.00213 \\
\hline $1 / 11 / 01$ & $10.5^{\circ}$ & 0.00217 \\
\hline $1 / 25 / 01$ & $9.6^{\circ}$ & 0.00227 \\
\hline $2 / 1 / 01$ & $7.8^{\circ}$ & 0.00224 \\
\hline $2 / 8 / 01$ & $4.2^{\circ}$ & 0.00214 \\
\hline $2 / 22 / 01$ & $9.5^{\circ}$ & 0.00223 \\
\hline $3 / 1 / 01$ & $11.3^{\circ}$ & 0.00231 \\
\hline Average & $\begin{array}{c}8.8^{\circ} \\
\left( \pm 2.3^{\circ}\right)\end{array}$ & $\begin{array}{c}0.00219 \\
( \pm 0.00008)\end{array}$ \\
\hline
\end{tabular}

(a) 0 degrees East; 90 degrees North.

RCRA monitor wells used in analysis: 299-W18-30, -W18-31, -W19-12, and -W19-42 
R.M. Smith

March 14, 2001

Page 19

Table 4. Groundwater-Flow Characterization Results Based on Trend-Surface Analysis: South RCRA U WMA Monitor Wells

\begin{tabular}{|c|c|c|}
\hline Measurement Date & $\begin{array}{c}\text { Groundwater-Flow } \\
\text { Direction }^{(a)}\end{array}$ & $\begin{array}{l}\text { Hydraulic Gradient, } \\
\mathrm{m} / \mathrm{m}\end{array}$ \\
\hline $11 / 3 / 00$ & $10.0^{\circ}$ & 0.00199 \\
\hline $11 / 30 / 00$ & $13.6^{\circ}$ & 0.00213 \\
\hline $12 / 28 / 00$ & $9.7^{\circ}$ & 0.00205 \\
\hline $1 / 11 / 01$ & $10.1^{\circ}$ & 0.00207 \\
\hline $1 / 25 / 01$ & $8.2^{\circ}$ & 0.00215 \\
\hline $2 / 1 / 01$ & $5.5^{\circ}$ & 0.00209 \\
\hline 2/8/01 & $4.5^{\circ}$ & 0.00201 \\
\hline $2 / 22 / 01$ & $5.4^{\circ}$ & 0.00207 \\
\hline $3 / 1 / 01$ & $4.7^{\circ}$ & 0.00209 \\
\hline Average & $\begin{array}{c}8.0^{\circ} \\
\left( \pm 3.1^{\circ}\right)\end{array}$ & $\begin{array}{c}0.00207 \\
( \pm 0.00005)\end{array}$ \\
\hline
\end{tabular}

(a) 0 degrees East; 90 degrees North.

RCRA monitor wells used in analysis: 299-W18-25, -W18-31, -W19-12, and -W19-41 


\section{Appendix B}

\section{Well Construction and Completion Summaries}




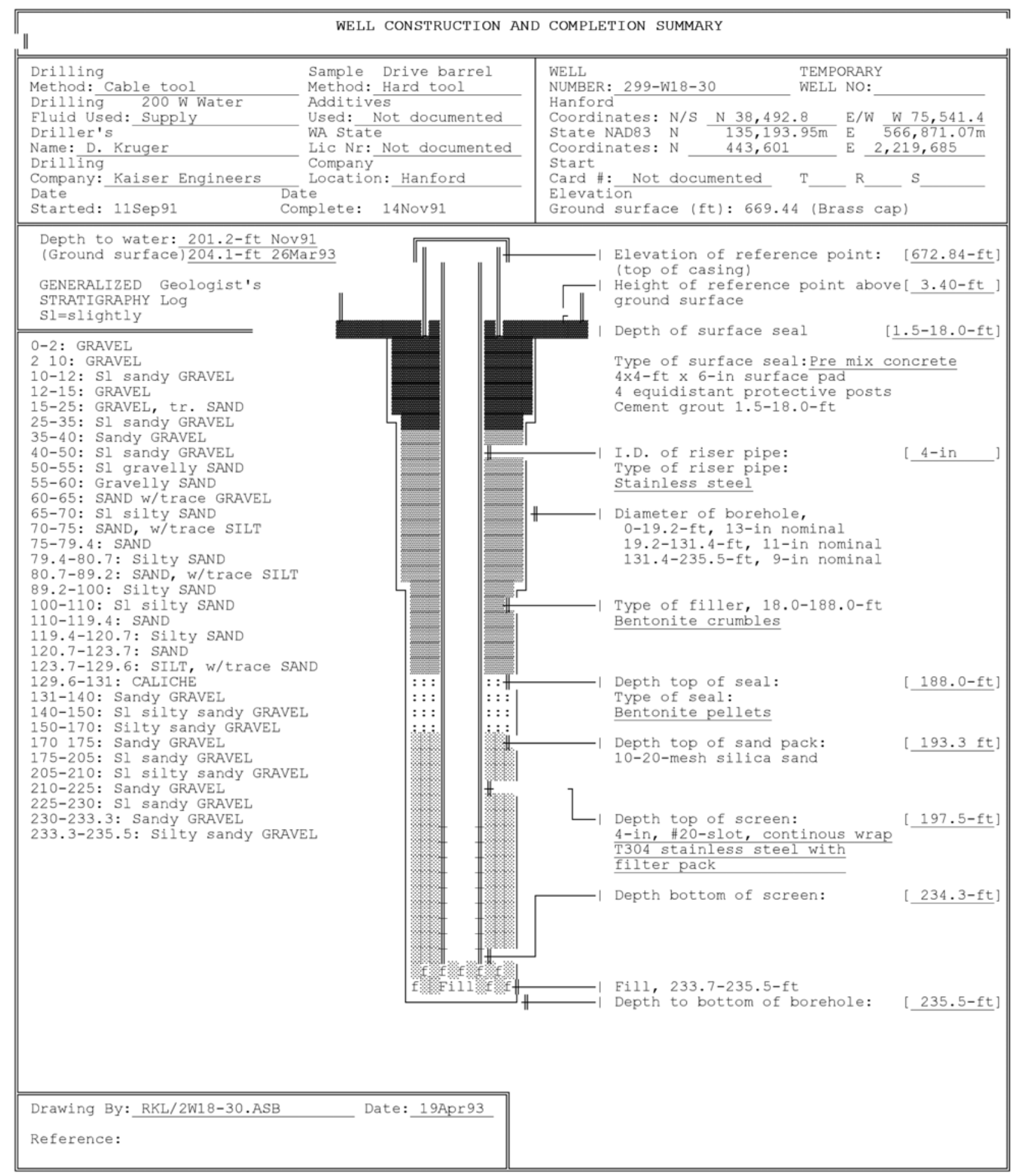




\begin{tabular}{|c|c|c|c|c|}
\hline \multirow{2}{*}{\multicolumn{2}{|c|}{ WELL SUMMARY SHEET }} & \multirow{2}{*}{\multicolumn{2}{|c|}{0503023}} & Boring or Well No. $299-$ W/8-30 \\
\hline & & & & Sheet 1, of \\
\hline \multirow{2}{*}{\multicolumn{2}{|c|}{$\begin{array}{l}\text { Location } 200 \text { west - } 241 \mathrm{k} \text { Foem } \\
\text { Elevation }\end{array}$}} & \multirow{4}{*}{\multicolumn{3}{|c|}{ 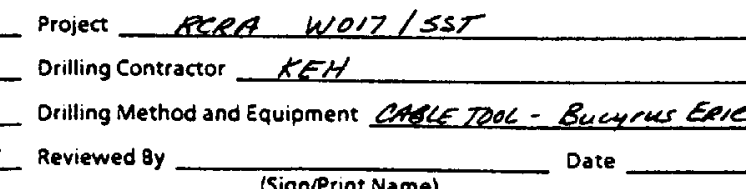 }} \\
\hline & & & & \\
\hline \multirow{2}{*}{\multicolumn{2}{|c|}{ 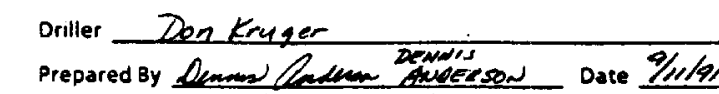 }} & & & \\
\hline & & & & \\
\hline \multicolumn{2}{|c|}{ CONSTRUCTION DATA } & \multicolumn{3}{|r|}{ GEOLOGICHYDROLOGIC DATA } \\
\hline \multicolumn{2}{|l|}{\begin{tabular}{l|l} 
Description \\
\end{tabular}} & Feet & Graphic Log & Lithotogic Description \\
\hline 12 "trmearany cerson steel & \multirow{8}{*}{ 网 } & \multirow{2}{*}{ 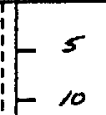 } & \multirow{2}{*}{$\begin{array}{l}\because \therefore \therefore \\
\because \therefore 0 \\
\because 0\end{array}$} & SANO \\
\hline CAsine to $19.16^{\prime 6} \mathrm{bls} \longrightarrow$ & & & & SUL SANOS GPAVEL \\
\hline \multirow{2}{*}{ 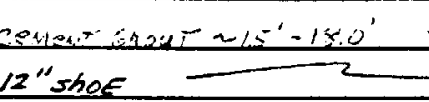 } & & \multirow{2}{*}{-20} & \multirow{3}{*}{$\begin{array}{l}0,00 \\
0.00 \\
0.00 \\
0.00\end{array}$} & GEAKEL \\
\hline & & & & GRAVEL $w /$ terce sand \\
\hline$\omega / 1 \prime^{\prime} \phi$ & & & & sild send GRAVEL \\
\hline & & & & siln sandy GRAVEL \\
\hline & & -35 & & sandy GeAvEL \\
\hline \multirow{3}{*}{ 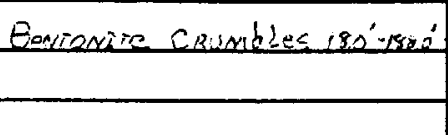 } & & -40 & & sluantly sondx GReAVL \\
\hline & 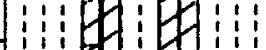 & -45 & & 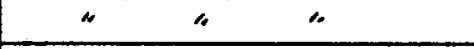 \\
\hline & H:Z & $-\infty$ & & slegntly granelly saWD \\
\hline & 車泊 & -55 & & grovelly sANA \\
\hline & (4: & -60 & & SAND N/ terce Gamel \\
\hline & 化if: & -65 & & 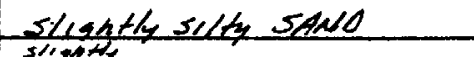 \\
\hline & Hiti & -70 & & sithy sano \\
\hline & 残: & -75 & & SANO \\
\hline $10 "$ temporen cerson & 化: & -80 & $\because$ & silty sowe \\
\hline steel casing to & 物：日： & -85 & & sleatly splty send \\
\hline $131.37^{\prime} 6 / 5$ & Hith & -90 & & sulth stand \\
\hline & 化 & -95 & & 114 \\
\hline & U & $-1 \infty$ & & Sleathy selon sandO \\
\hline & 妇: & ror & & 4 \\
\hline & Hithi & -110 & & SANO \\
\hline & Hithi: & -115 & & SAND \\
\hline & & & & $\sin \operatorname{sen} \theta$ \\
\hline $10^{\circ}$ shoe $\% .99^{\prime} \phi \longrightarrow$ & He & & & $+\quad w /$ caliche 2129 \\
\hline & 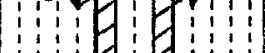 & - & : & send, GeAvels \\
\hline 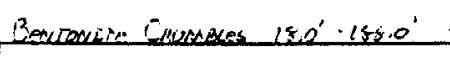 & Hii & -14 & $\because 0$ & slignthy sithy sendy Gexvels \\
\hline & Gi & -145 & $\because-0$ & selty sendy GeAVEL \\
\hline 8"temporary ceechon steel & 白肖: & -15 & :08 & " $"$. \\
\hline caseme to $235.5^{\prime} \mathrm{b} / \mathrm{s}$ & 的电 & -155 & $\overline{\sigma_{0}}$ & “ \\
\hline & 目管 & $-1 / 60$ & 000 & $"$ \\
\hline & & & $0 \div$ & " \\
\hline
\end{tabular}




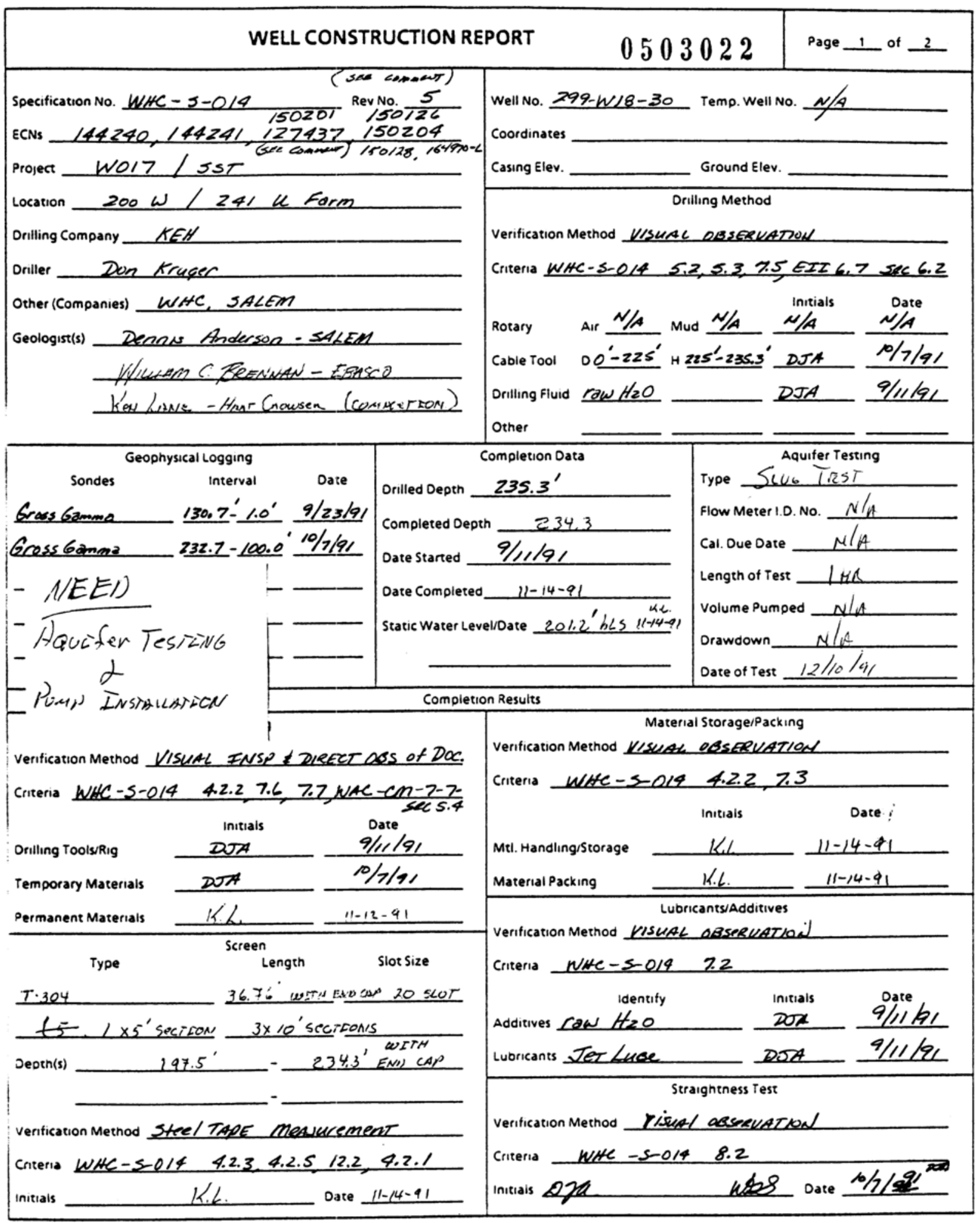




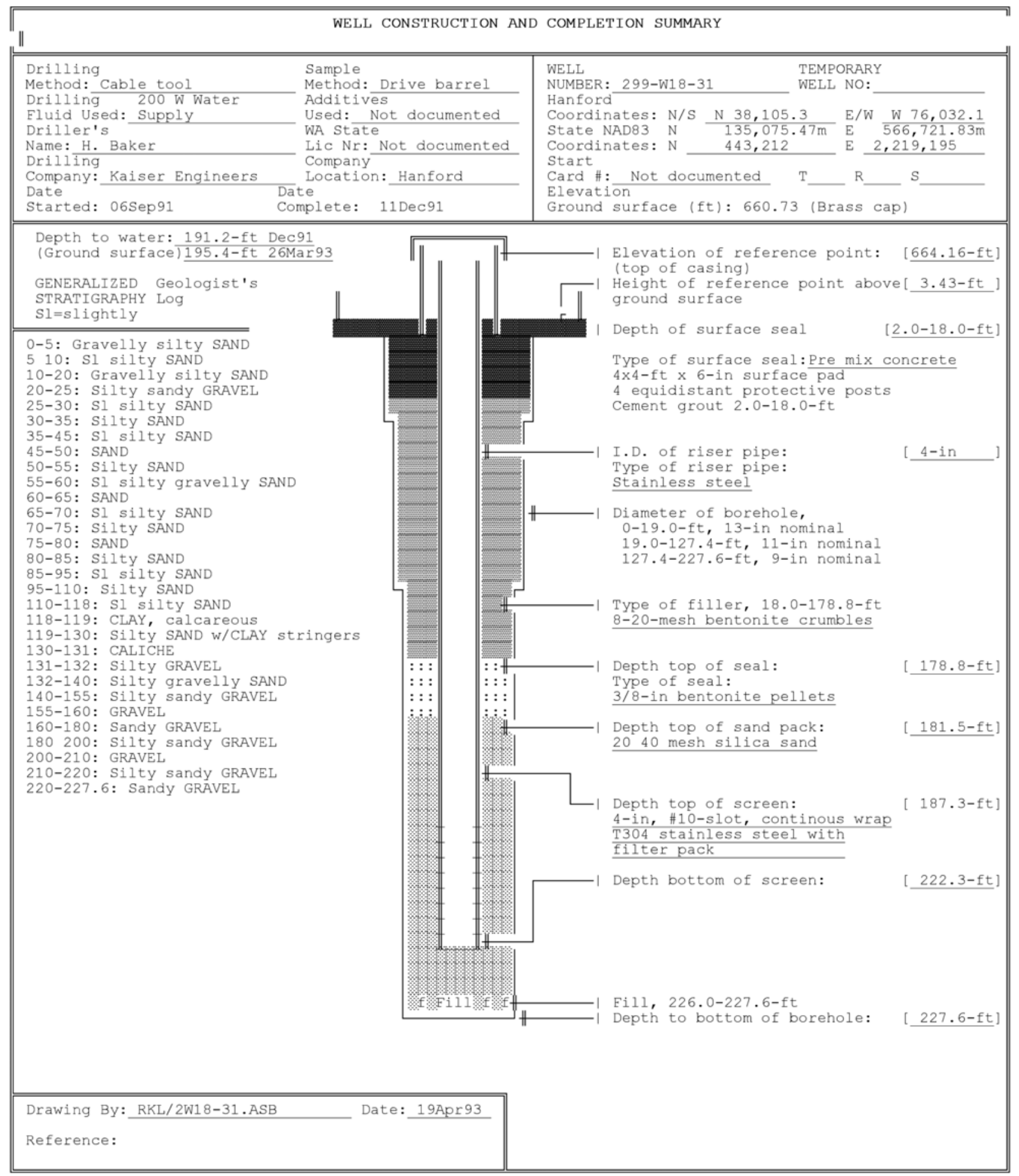




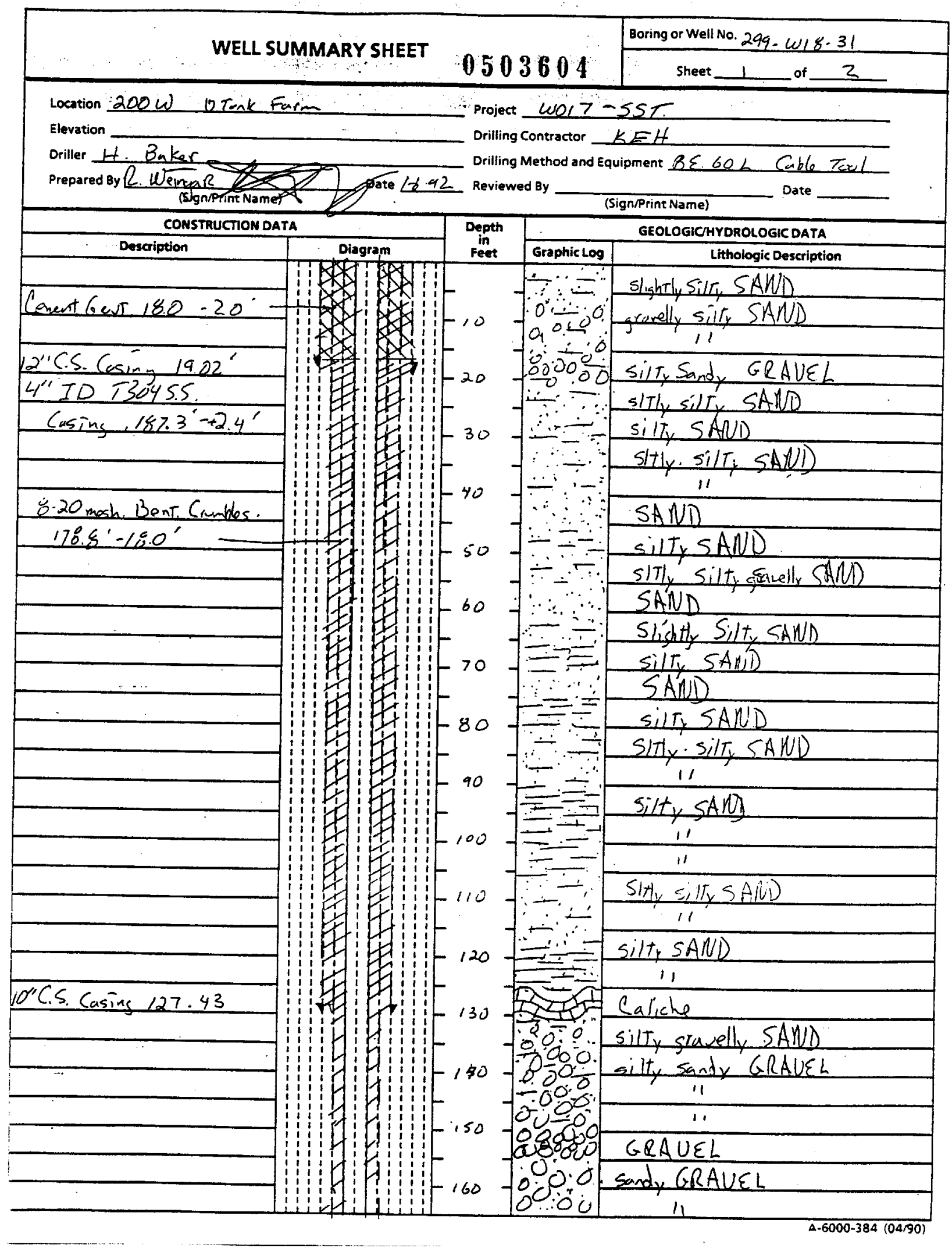




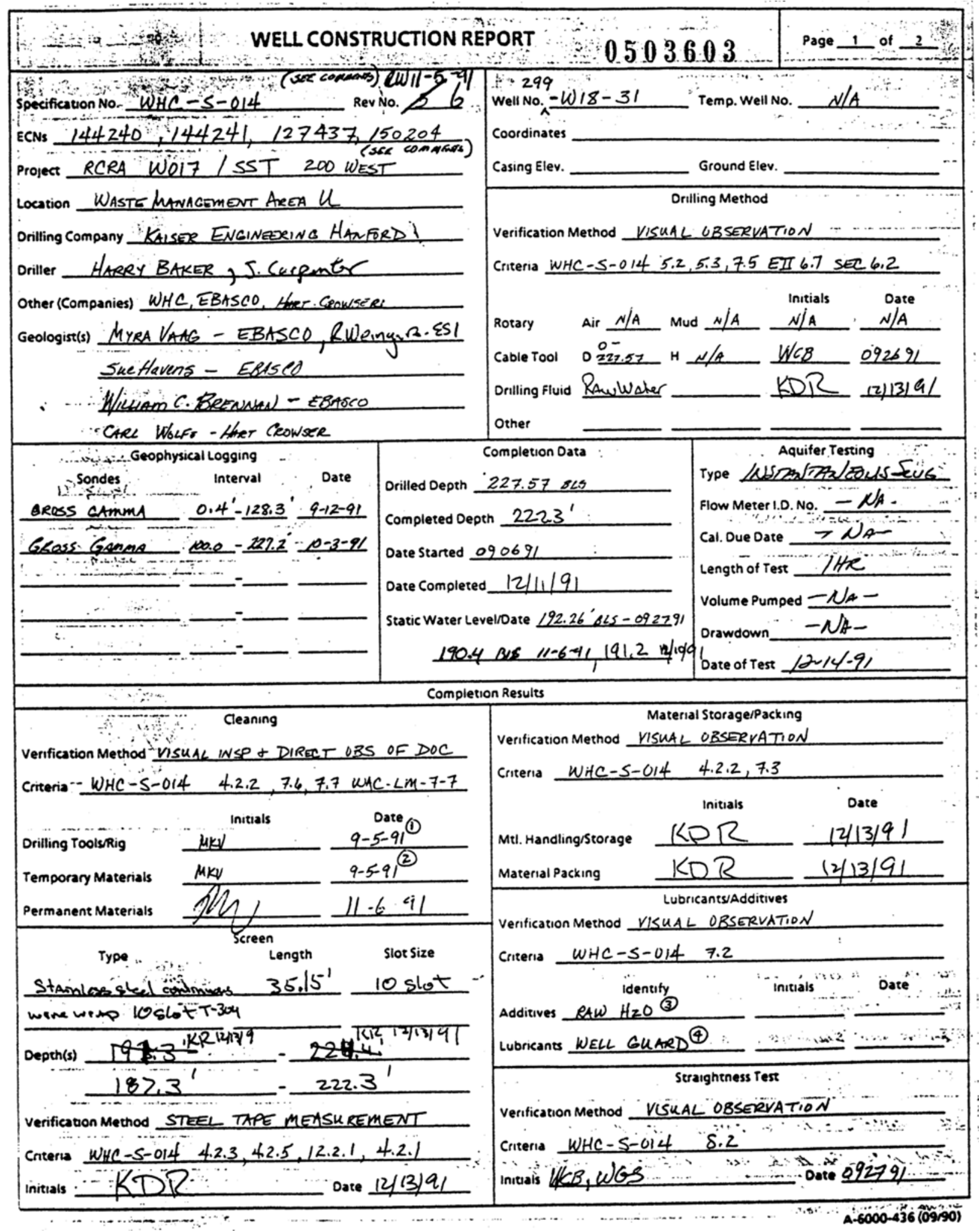




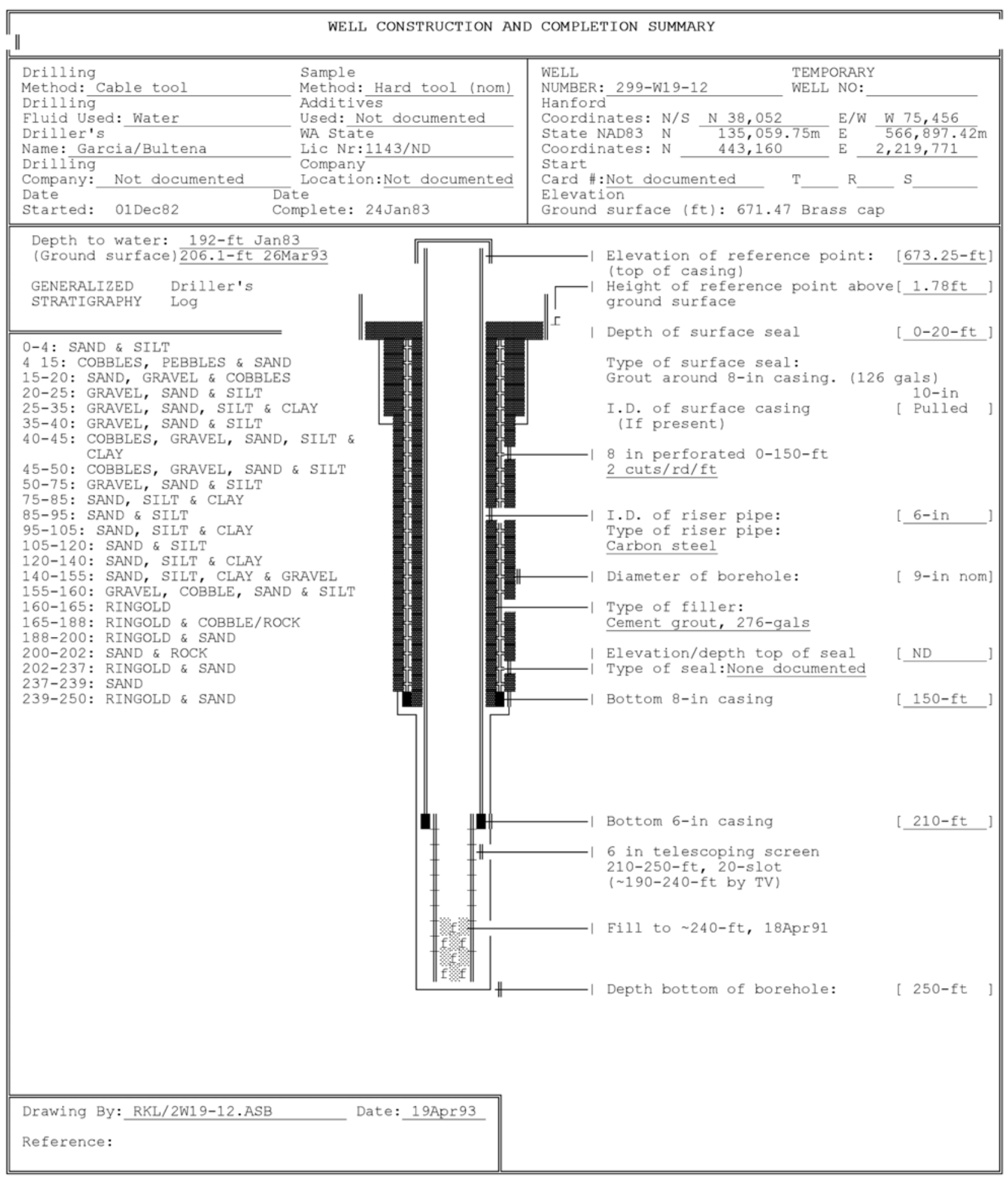


0502374

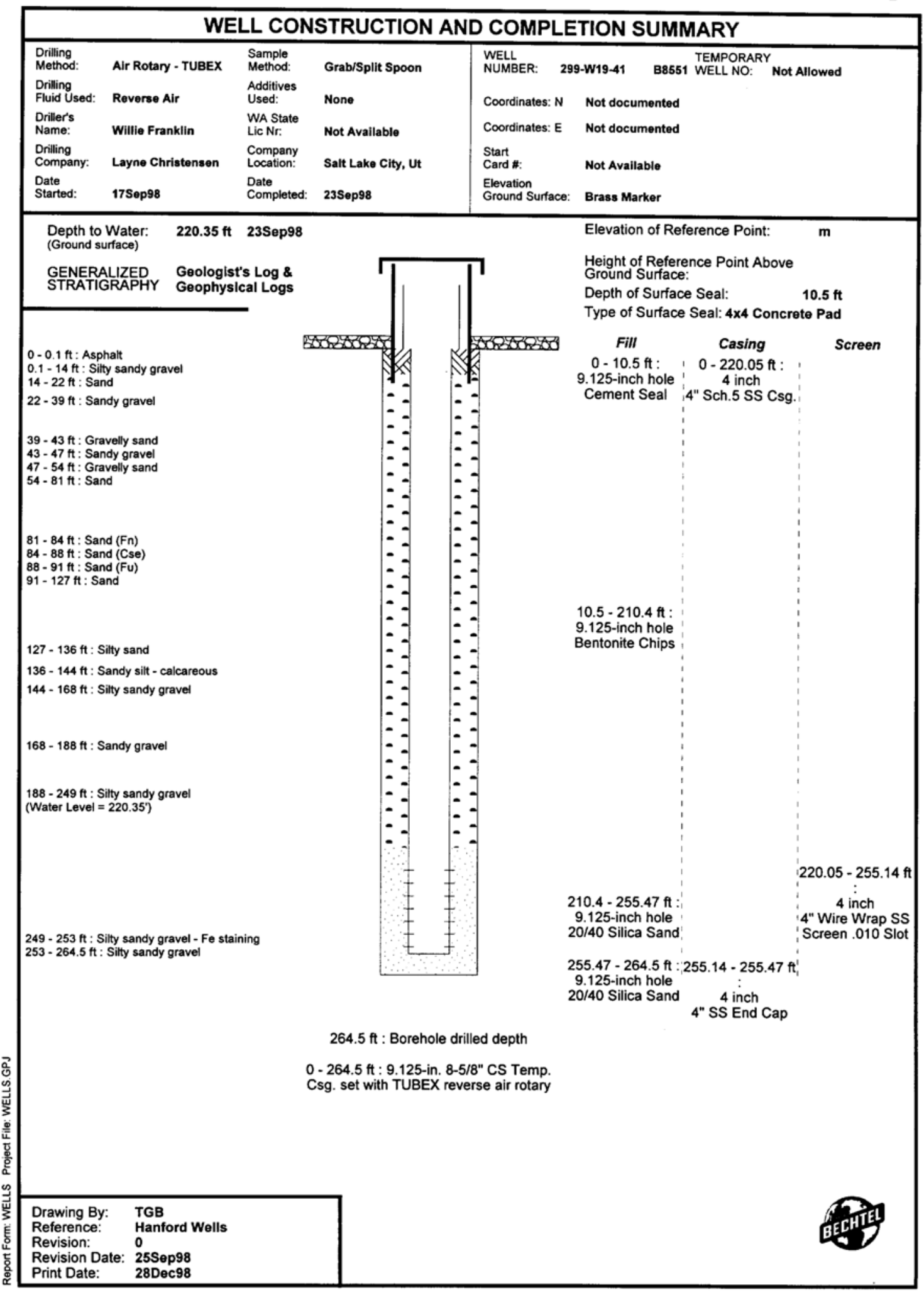


0502441

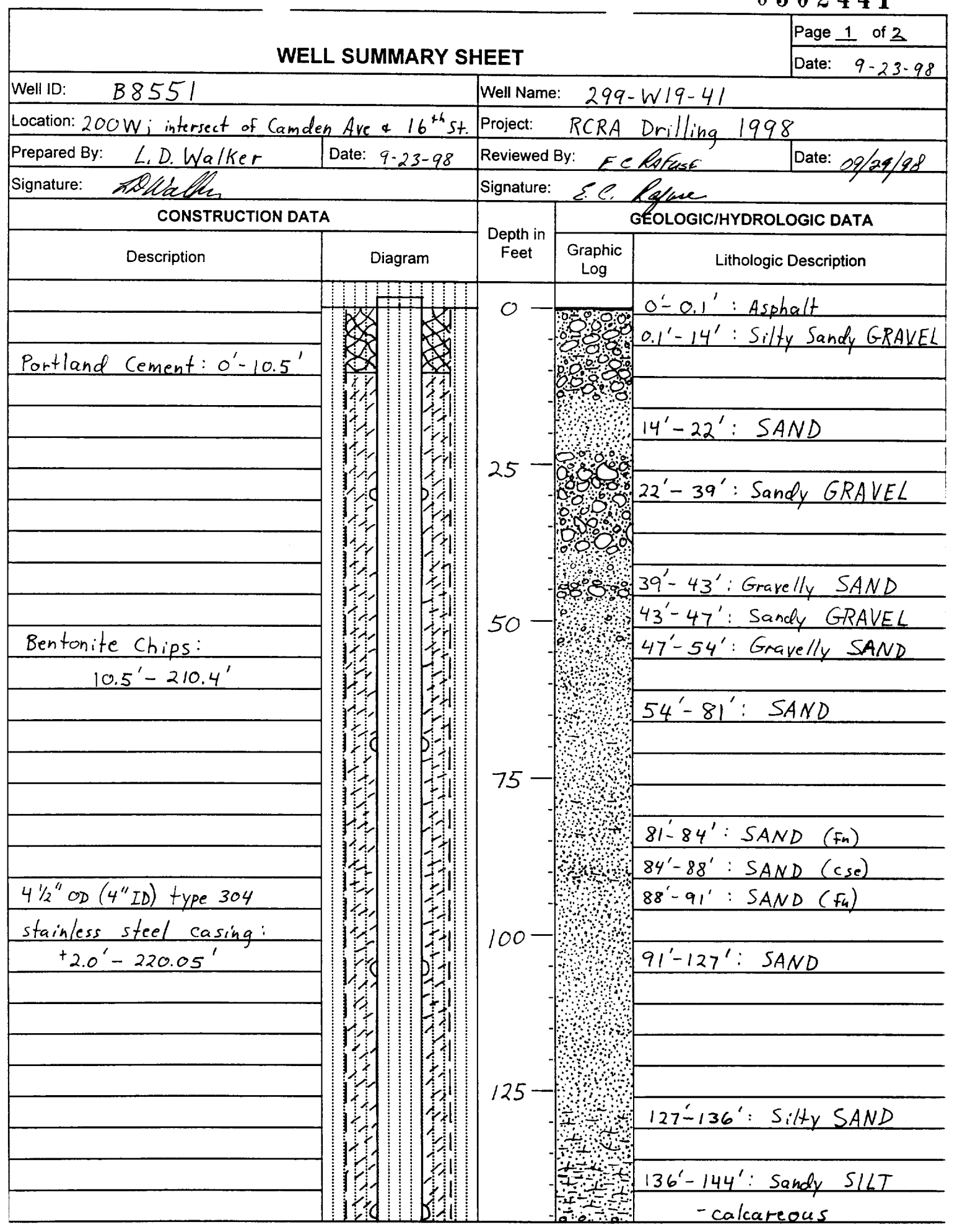




\begin{tabular}{|c|c|c|c|c|c|c|}
\hline \multirow{3}{*}{\multicolumn{4}{|c|}{ WELL CONSTRUCTION SUMMARY REPGRT0 }} & \multicolumn{3}{|c|}{ Start Date: $9-17-98$} \\
\hline & & & & \multicolumn{3}{|c|}{ Finish Date: $9-23-98$} \\
\hline & & & & \multicolumn{3}{|c|}{ Page 11 of 1} \\
\hline \multirow{2}{*}{\multicolumn{3}{|c|}{$\begin{array}{l}\text { Specification No.: } \begin{array}{c}0200 x-5 p- \\
\text { vo00 }\end{array} \\
\text { ECNs: } \quad \text { Rev. No.: } 1 \\
\end{array}$}} & \multirow{2}{*}{\multicolumn{4}{|c|}{$\begin{array}{l}\text { Well Name: } 299-\text { W } 19.41 \\
\text { Approximate Location: inter sect, of Camden Ave } 416^{\text {th }} \text { st, }\end{array}$}} \\
\hline & & & & & & \\
\hline & \multicolumn{4}{|c|}{ Other Companies: $\mathrm{CH}_{2} \mathrm{M} \mathrm{Hill}{ }^{2} 200 \mathrm{~W}$} \\
\hline \multicolumn{3}{|c|}{$\begin{array}{l}\text { Project: RCRA Drilling } 1998 \\
\text { Drilling Company: Layne Christensen }\end{array}$} & \multirow{2}{*}{\multicolumn{4}{|c|}{ Geologist(s): L.D. Walker }} \\
\hline \multicolumn{3}{|c|}{ Driller: W. Franklin } & & & & \\
\hline \multicolumn{3}{|c|}{ TEMPORARY CASING AND DRILL DEPTH } & \multicolumn{4}{|c|}{ DRILLING METHOD/HOLE DIAMETER } \\
\hline "Size/Grade/Lbs. Per Ft. & \begin{tabular}{|l|l|} 
Interval & \\
\end{tabular} & Shoe O.D.I.D. & Auger: & \multicolumn{3}{|c|}{ Diameter From __ to } \\
\hline \multirow[t]{5}{*}{$85 / 8^{\prime \prime} O D C S$ (FJ) } & $0^{\prime}-264.5$ & $85 / 8^{\prime \prime} / 8^{\prime \prime}$ & Cable Tool: & \multicolumn{3}{|c|}{ Diameter From _ to } \\
\hline & $=-$ & & Air Rotary: $O d$ ex, $9 y_{2}^{\prime \prime}$ & Diameter From $\quad 0$ & $5^{\prime}$ to 3 & $2645^{\prime}$ \\
\hline & $=-$ & & A.R. w/Sonic: & Diameter From & = to & \\
\hline & $=-$ & & & Diameter From & 工 to & \\
\hline & $=-$ & & & Diameter From & - to & \\
\hline \multicolumn{3}{|c|}{ "Indicate Welded (W) - Flush Joint (FJ) Coupled (C) \& Thread Design } & & \multicolumn{3}{|c|}{ Diameter From__ to } \\
\hline & & & Note on water added: & all at totald & depth 12 & $\left.264.5^{\prime}\right)$ \\
\hline & & & to keep Fine sediment & out of bore & rehole & \\
\hline & & $100423-98$ & Drilling Fluid: $A$ ir & & & \\
\hline Total Drilled Depth: 264,5 & Hole Dia @ TD: & $7 / / 2=91 / 8^{\prime \prime}$ & Total Amt. Of Water Added During & $\sim 300 \mathrm{~s}$ & gal. ${ }^{*}$ & \\
\hline Well Straightness Test Results: & & & Static Water Level: $220,35^{\prime}$ & Date: $9-23-98$ & & \\
\hline & & GEOPHYSICAL & AL LOGGING & & & \\
\hline Sondes (type) & Interval & Date & Sondes (type) & Interval & Date & \\
\hline & $=$ & & & $={ }^{-}=$ & & \\
\hline & $=-$ & & & $=-$ & & \\
\hline & $=$ & & & $=-$ & & \\
\hline & & COMPLETE & ED WELL & & & \\
\hline Size/Wt./Material & Depth & $\begin{array}{l}\text { Slot } \\
\text { Size }\end{array}$ & Type & \begin{tabular}{c|c|} 
Interval & \\
Annual Seal/Filter Pack \\
\end{tabular} & \begin{tabular}{|l} 
Volume \\
$(\mathrm{F}+3)$ \\
\end{tabular} & $\begin{array}{c}\text { Mesh } \\
\text { Size } \\
\end{array}$ \\
\hline 4"ID SS & $\pm 2.0-220.05$ & NA & Partland Cement & $0^{\prime}-10.5^{\prime}$ & $5.14 \mathrm{Ff}$ & $N A$ \\
\hline 4" ID SS wile wrap & $220.05^{\prime}-255.14^{\prime}$ & $0.010-$ in & Bentonite Chips & $10.5^{\prime}-210.4^{\prime}$ & 66.24 & medium \\
\hline $4^{\prime \prime}$ ID SS & $255.14^{\prime}-255.47^{\prime}$ & NA & Silice sand & $210.4^{\prime}=264.5$ & 29.68 & $20-40$ \\
\hline & $=-$ & & & ${ }^{-}$ & & \\
\hline & $=-$ & & & $=-$ & & \\
\hline & & OTHER AC & CTIVITIES & & & \\
\hline Aquifer Test: & & Date: & Well Abandoned: & Yes: & Date: & \\
\hline Description: & & & Description: & & & \\
\hline & & WELL SURV & VEY DATA & & & \\
\hline Date: & & & Protective Casing Elevation: & & & \\
\hline Washington State Plane Coordinat & & & Brass Cap Elevation: & & & \\
\hline & & COMMENTS/I & /REMARKS & & & \\
\hline$C S=$ carbon steel, $S S=s$ t & tainless steel & L. Volume Ca & a/c: cement: $1.285 x$ & $4=5.14 \mathrm{ft}^{3}$, & bentonit & \\
\hline chips $=0.69 \times 96=$ & $66.24 \mathrm{Ft}^{3}$, & 20.40 Silis & ica Sand $=1.12 \times 26$ & $5=29.68 \mathrm{ft}$ & & \\
\hline Reported By: L. D. Wa/Ke & & & Ee kata & eses & & \\
\hline Title: $\quad$ Geologist & & Date: $9-23-98$ & Title: FiEL ENaimed & $(8,12)$ & Date:og/e & lages \\
\hline Tocualer & & & Signature: $\angle C$ Rolpe & & & \\
\hline
\end{tabular}


0502376

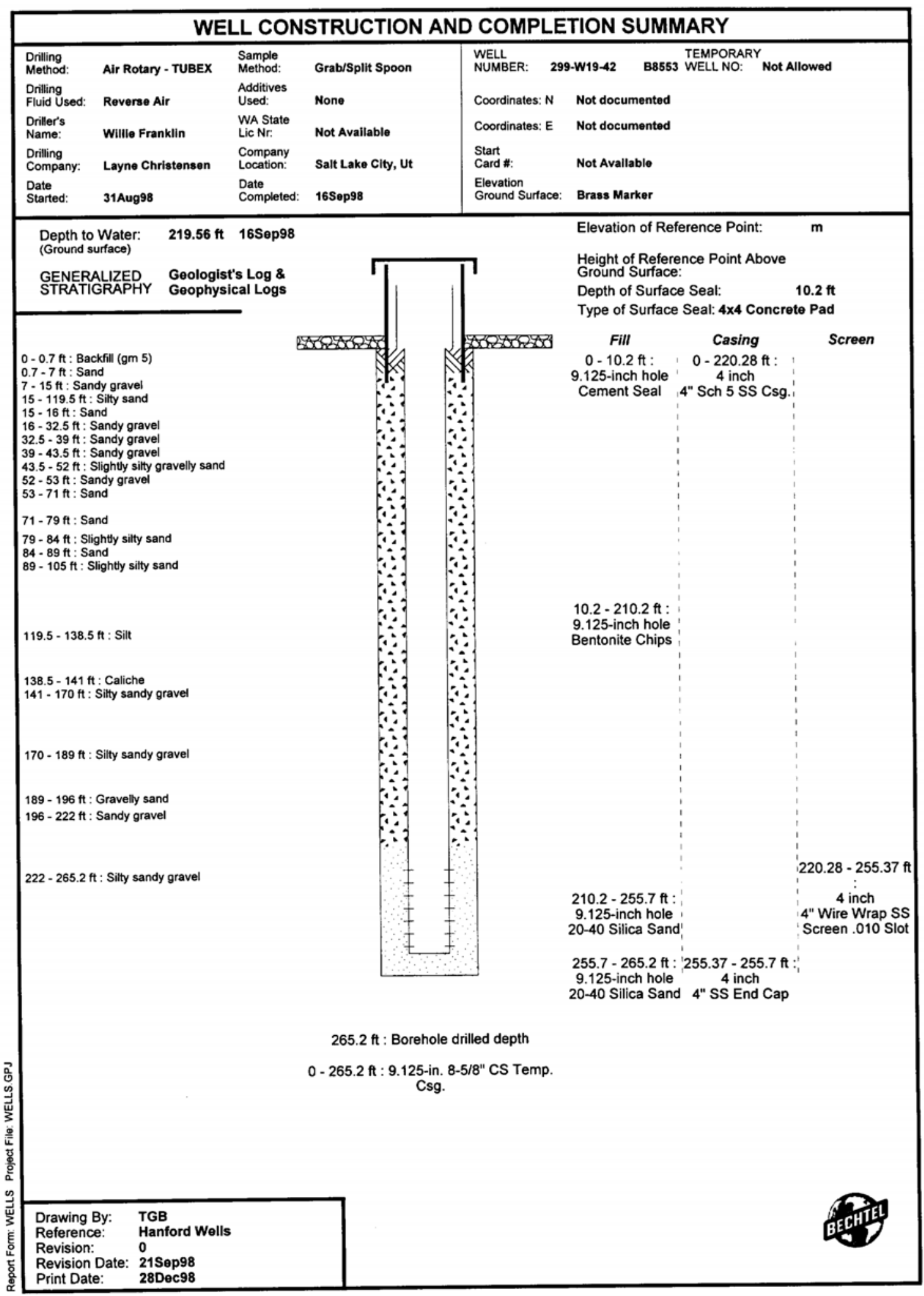


0502439

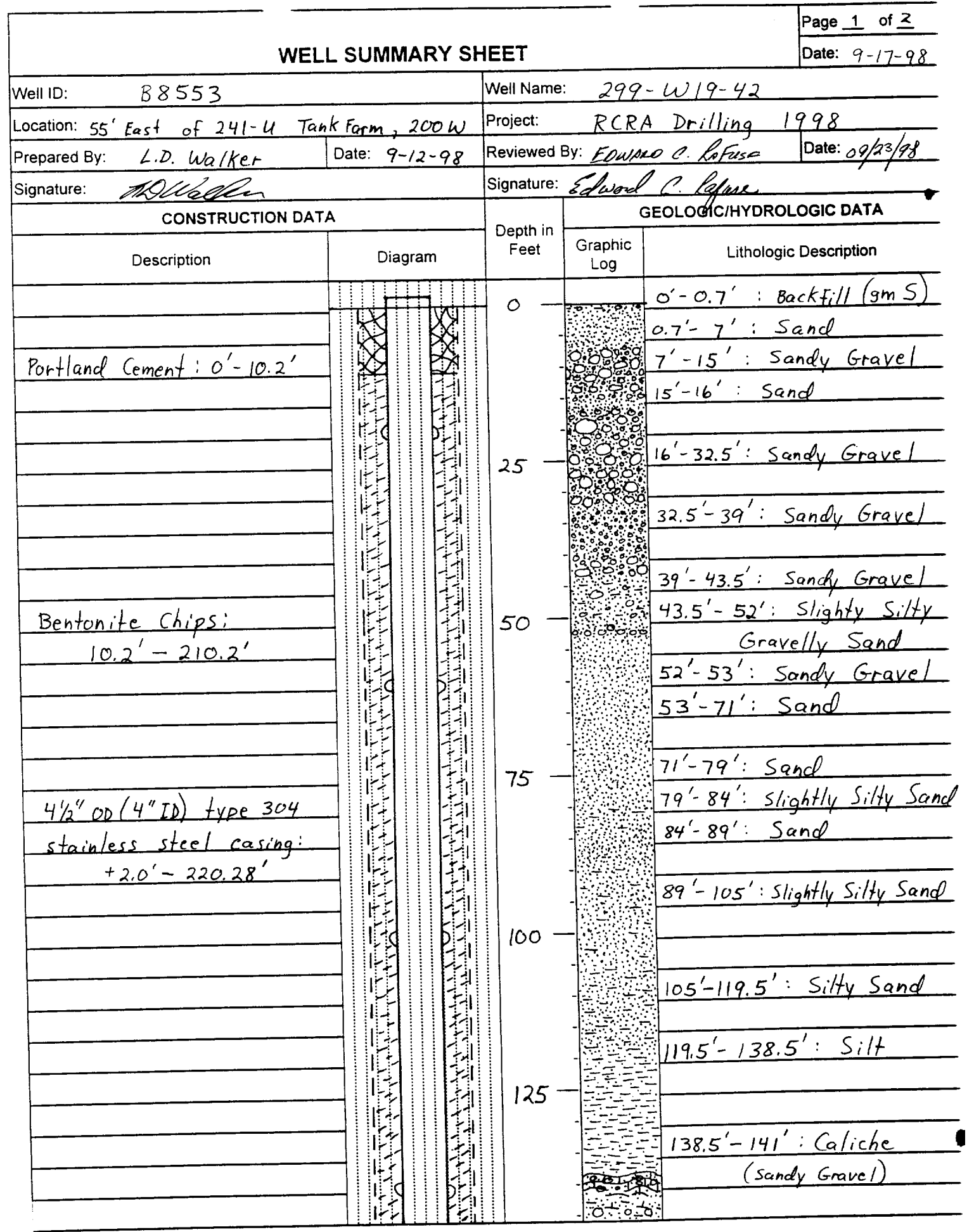

BHI-EE-189 (12/97)

B. 12 


\begin{tabular}{|c|c|c|c|c|c|c|c|}
\hline \multirow{3}{*}{\multicolumn{5}{|c|}{ WELL CONSTFUCTION SUMMARY REPOR । }} & \multicolumn{3}{|c|}{ Start Date: $\quad 8 / 31 / 98$} \\
\hline & & & & & \multicolumn{3}{|c|}{ Finish Date: $\quad 9-16-98$} \\
\hline & & & & & \multicolumn{3}{|c|}{ Page 1 of 1} \\
\hline $\begin{array}{l}\text { Specification No.: } 0200 \mathrm{X}-5 \mathrm{P}= \\
\mathrm{V} 000 \mathrm{O}\end{array}$ & \multicolumn{3}{|l|}{ Rev. No.: / } & Well Name: $299-w 19-42$ & \multicolumn{3}{|c|}{ Well No.: $B 8553$} \\
\hline \multicolumn{4}{|c|}{ ECNs: $N A$} & \multicolumn{4}{|c|}{ Approximate Location: $55^{\prime}$ Egs tof $244-U$ Tank Fim, $200 \mathrm{~W}$} \\
\hline \multicolumn{4}{|c|}{ Project: RCRA Drilling 1998} & \multicolumn{4}{|c|}{ Other Companies: $\mathrm{CH} 2 \mathrm{~m} \mathrm{Hill}$} \\
\hline \multicolumn{4}{|c|}{ Drilling Company: Layne Christensen } & \multirow{2}{*}{\multicolumn{4}{|c|}{$\begin{aligned} \text { Geologist(s): } & \text { DCWeekes } \\
& \text { LD Walker }\end{aligned}$}} \\
\hline \multicolumn{4}{|c|}{ Driller: M. Wraspir / W. Franklin } & & & & \\
\hline \multicolumn{4}{|c|}{$\begin{array}{l}\text { TEMPORARY CASING AND DRILL DE.PTH } \\
\end{array}$} & \multicolumn{4}{|c|}{ DRILLING METHOD/HOLE DIAMEIER } \\
\hline -Size/Grade/Lbs. Per Ft. & \begin{tabular}{|c|} 
Interval \\
\end{tabular} & \multicolumn{2}{|c|}{ Shoe O.D.I.D. } & Auger: & \multicolumn{3}{|c|}{ Diameter From __ to } \\
\hline $9^{\prime \prime} O D$ carbon stee /(FJ) & $0^{\prime} \cdot 135.7$ & \multirow{2}{*}{\multicolumn{2}{|c|}{$\frac{0.8^{\prime} / 0.7^{\prime}}{85 / 8^{\prime \prime} / 8^{\prime \prime}}$}} & Cable Tool: Drive barrel & \multicolumn{3}{|c|}{ Diameter From $O^{\prime}$ to $140^{\prime}$} \\
\hline \multirow[t]{4}{*}{$85 / 8 " O D C S$ (FJ) } & $0^{\prime}-265.2^{\prime}$ & & & Air Rotary: Odex; $9^{1 / 2 "}$ & \multicolumn{3}{|c|}{ Diameter From $\mathrm{O}^{\prime}$ to $265.2^{\prime}$} \\
\hline & $=$ & & & A.R. w/Sonic: & \multicolumn{3}{|c|}{ Diameter From ___ to } \\
\hline & $=$ & & & & Diameter From & to & \\
\hline & $=$ & & & & Diameter From & $=$ to & \\
\hline "Indicate Welded (W) - Flush Join & nt (FJ) Coupled (C) & \& Thread & Design & & Diameter From & $=$ to & \\
\hline & & & & Note on water added: & all at total de & esth 1 & \\
\hline & & & & keep fine sediment out & I of casing & & \\
\hline & & & & Drilling Fluid: Air & & & \\
\hline Total Drilled Depth: $\quad 265.2$ & Hole Dia @ TD: & $91 / 2 "$ & & Total Amt. Of Water Added During & Drilling: $2300 \mathrm{ga}$ & & \\
\hline Well Straightness Test Results: & $N A$ & & & Static Water Levei: $219.56^{\prime} \mathrm{bgs}$ & Date: $9-16-98$ & & \\
\hline & & GEO & PHYSICAL & L LOGGING & & & \\
\hline Sondes (type) & Interval & $\mathrm{Da}$ & & \begin{tabular}{|c|} 
Sondes (type) \\
\end{tabular} & Interval & Dat & \\
\hline Spectral Gamma (kuT $+{ }_{\text {Ss:in }}$ & $0^{\prime} \cdot 139$ & $9-9$ & -98 & Spectral Gamma KuT & $118^{\prime}-262^{\prime}$ & $9-13$ & -98 \\
\hline Neutron & $0^{\prime} \cdot 136^{\prime}$ & $9-9$ & -98 & Neutron & $120^{\prime} \cdot 219^{\prime}$ & $9-13$ & -98 \\
\hline & $=\cdot$ & & & & $=-1$ & & \\
\hline & & & OMPLETE & ED WELL & 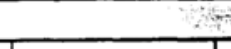 & - & ser \\
\hline Size/Wt./Material & Depth & Thread & \begin{tabular}{l|l} 
Slot \\
Size
\end{tabular} & Type & $\begin{array}{c}\text { Interval } \\
\text { Annual Seaulfiltor Pack } \\
\end{array}$ & Volume $\left(\mathrm{E}+^{3}\right)^{\circ}$ & \begin{tabular}{|c|} 
Mesh \\
Size \\
\end{tabular} \\
\hline $4^{\prime \prime}$ ID SS & $+2.0-220.28$ & FI & $N A$ & Portland Cement & $0^{\prime} \cdot 10.2^{\prime}$ & 30.84 & $N A$ \\
\hline 4" ID SS wire wrap & $220.28^{\prime} \cdot 255.37^{\prime}$ & FJ & $0.010-i n$ & Bentonite Chips & $10.2^{\prime} \cdot 210.2$ & 75.21 & medium \\
\hline $4 "$ ID SS & $255,37^{\prime}-255,70^{\prime}$ & FJ & NA & Silica Sand & $210.2^{\prime}=265.1^{\prime}$ & 29.68 & $20-40$ \\
\hline & $=$ & & & & $=$ & & \\
\hline & $=$ & & & & $=-$ & & \\
\hline & & & THER AC: & CTIVITIES & & 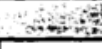 & 侄. \\
\hline Aquifer Test: & & Date: & & Well Abandoned: & Yes: & Date: & \\
\hline Description: & & & & Description: & & & \\
\hline & & & ELL SURV & VEY DATA & & $\sin$ & \\
\hline Date: & & & & Protective Casing Elevation: & & & \\
\hline Washington State Plane Coordinat & & & & Brass Cap Elevation: & & & \\
\hline & & & MMENTSI & S/REMARKS & & & $9-2$ \\
\hline$C S=$ carbon steel: $S S=$ sta & inless steel; $V$ & Volume $C$ & alc: ce & ement $=1.285 \times 24=30.84$ & $4 \mathrm{Ft}^{3}$, Bentonite & chips & \\
\hline $0.69 \times 109=75.21 \mathrm{Ff}^{3}$, & $20-40$ silica & a sancl & $=1.12$ & $2 \times 26.5=29.68 \mathrm{Ft}^{3}$ & & & \\
\hline Reported By: L.D. Wa/ke & & & & Reported By: E.C. Lafus & & & \\
\hline Title: $\quad$ Geologist & & Date: 9 & $-17-98$ & Title: FiELL FNGinex & (BNI & Date: of & $9 / 23 / 91$ \\
\hline Signature: 15 Calls & 2 & & & Signature: S.C. Rele & & & \\
\hline
\end{tabular}




\section{Distribution}

No. of

Copies

ONSITE

12 DOE Richland Operations Office

M. J. Furman (8)

J. G. Morse

K. M. Thompson

R. M. Yasek

Public Reading Room

\section{CH2M HILL Hanford Group}
A. J. Knepp
$\mathrm{H} 0-22$
D. A. Myers
$\mathrm{H} 0-22$
T. E. Jones
H0-22

No. of

Copies

12 Pacific Northwest National Laboratory

$\begin{array}{lr}\text { C. J. Chou } & \text { K6-81 } \\ \text { J. S. Fruchter } & \text { K6-96 } \\ \text { F. N. Hodges } & \text { K6-81 } \\ \text { V. G. Johnson } & \text { K6-96 } \\ \text { S. P. Luttrell } & \text { K6-96 } \\ \text { R. M. Smith (4) } & \text { K6-96 } \\ \text { B. A. Williams } & \text { K6-81 } \\ \text { Hanford Technical Library (2) } & \text { P8-55 }\end{array}$

